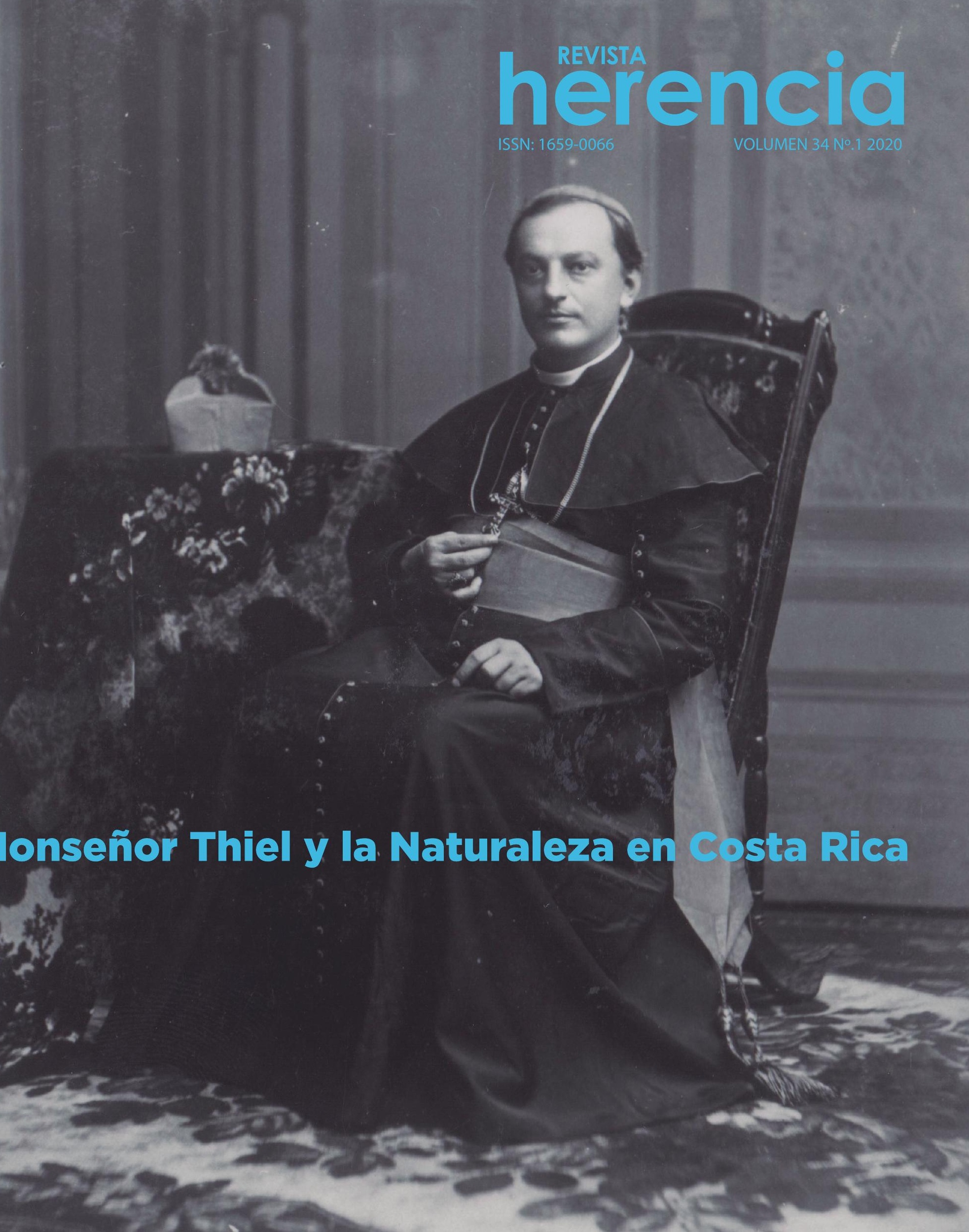


306.05

R454r Revista herencia. - Año 1, N. 1 (1988)-.-

(San José, C. R.): Programa de Rescate y Revitalización del Patrimonio Cultural, 1988-v,

Semestral.

1. Costa Rica - Civilización - Publicaciones periódicas. 2. Folclore

- Costa Rica - Publicaciones periódicas.

ISSN 1659-0066

\section{CCC/BUCR}

$\bigcirc$

\section{Revista herencia Vol. $33(2), 2020$}

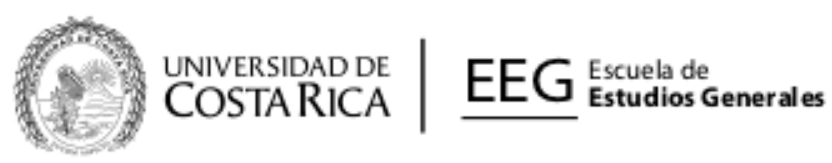

Herencia Semestral

ISSN 1659-0066

La revista Herencia es una publicación semestral de la Escuela de Estudios Generales de la Universidad de Costa Rica. Su propósito es la difusión de articulos sobre el rescate y la revitalización del patrimonio cultural.

\section{Consejo Editorial}

Dra. Macarena Barahona Riera, Excuela de Estudios Generales, Unversidad de Costa Pica, Costa Pica Dra. Susan Campos Fonseca, Sode del Allíricico, Escuela de Artes Muricales.

Universidad de Costa Rea, Costa Pica

Lic. Mel Vun Campos Ocampo, Escuela de Estudos Generales, ICOMOS de Costa Rica, Costa Rica Dr. Maricio M.rilo Herrera, Escuela de Antropologla, Universidad de Costa Rica, Costa Pica

Mag. Jaral Nunaz Moya, Escuela de Estudos Generaies, Unversidad de Costa Rica, Costa Rica M. So Claudo Vergas Avias, Escuela de Historia. Urwersidad de Costa Rica Costa Rica.

\section{Director-Editor}

Mag. Jairol Núnez Mop

Asistente y Soporte Web

Br. Jonathan Obando Artiaga

\section{Consejo Asesor Externo}

Dr. Jorge Barios, Ecole Lacarierne de Psychanalyse, Avgerína

Excmo ismael Ferndindez de la Cuesta, Acadomia de Bellas Avtes Son Femanda, Espara Avq, Andrès Fernindez, Espocialista en Patsimonia, Costa Rica

Dr. Aurdio Horta, Urversidad Naciona, Colombia.

Ora. Olga Joya, Universidad Nocional Autsonoma de Hondtras, Honderas

Mag. Mried Reinoso, Grupo Edtorial Dostempos. Mbrico

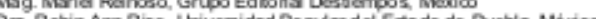
Dr. Luis Thenon. Universidad de Laval, Canats

Dra. Marla Femanda Ugaide. Pontficia Universidad Canolica del Ecusdor, Ecuadoe Mag. Marlene Viaquez. Centro de Estudios Martianos, Cubo

Dra Matina Vinatea, Unversid ad del Pacifica, Perú

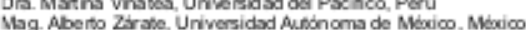
Dra. Magda Zarala. Unversidad Nacional Costa Rica

Disen̂o, diagramación y edición

Mag. Jürol Nuntez Moye

Corrección-de estito Mag. Jairol Núnez Moya

Escuela de Estudios Generales.

Universidad de Costa Rica.San Pedro de Montes de Oca, San José, Costa Rica.

Correo electrónico: herencia.eeg@ucr.ac.cr / Teléfono: (506) 2511-6342

http://revistas.ucr.ac.cr/index.php/herencia

Las opiniones expresadas en los artículos son responsabilidad exclusiva de los autores y las autoras y no reflejan necesariamente la posición de la Revista.

Imagen de portada de Separata: Monseñor Bernardo Augusto Thiel

Foto: Harrison N. Rudd.

Copyright (C) 2020

Todos los derechos reservados 


\title{
MONSEÑOR THIEL Y LA NATURALEZA EN COSTA RICA
}

\author{
Luko Hilje
}

Revista Herencia 33 (2), 2020 
Hilje, L. (2020). Monseñor Thiel y la naturaleza en Costa Rica.

Revista Herencia 33 (2), julio-diciembre, 123-202.

\title{
MONSEÑOR THIEL Y LA NATURALEZA EN COSTA RICA
}

\author{
Monseñor Thiel and nature in Costa Rica
}

\begin{abstract}
Luko Hilje
Centro Agronómico Tropical de Investigación y Enseñanza (CATIE), Costa Rica

luko@ice.co.cr
\end{abstract}

Recibido: 02-03-2020

Aprobado: 27-03-2020

\begin{abstract}
Luko Hilje Quirós es Licenciado en Biología y doctor en Entomología, miembro de la Asamblea de Fundadores del Instituto Nacional de Biodiversidad (INBio) y miembro honorario del Colegio de Ingenieros Agrónomos de Costa Rica. Es Profesor Emérito del Centro Agronómico Tropical de Investigación y Enseñanza (CATIE), Turrialba, Costa Rica.
\end{abstract}

\section{RESUMEN}

Durante su mandato como obispo de Costa Rica (1880-1901), el polifacético sacerdote alemán Bernardo Augusto Thiel no se limitó a sus exigentes funciones eclesiásticas, sino que incursionó en la etnografía, la lingüística, la antropología, la historia y la demografía. En el presente artículo se documenta una faceta más, referida a las ciencias biológicas. Ello se manifestó en numerosas anotaciones acerca de la flora y la fauna en sus crónicas de viaje, escritas durante sus jornadas de evangelización en territorios indígenas. Además, tuvo una colección de objetos arqueológicos y de aves, entre las que figuró Iridophanes pulcherrimus aureinucha, recolectada en Ecuador y después descrita como una subespecie nueva para la ciencia. Finalmente, impulsó acciones para el desarrollo de un medicamento antiofídico de origen vegetal, y expresó con vehemencia su preocupación por la deforestación que ya se percibía en el país.

Palabras clave: flora; fauna; aves; territorios indígenas; ofidismo; deforestación;Costa Rica

\begin{abstract}
While acting as the bishop of Costa Rica (1880-1901), Bernardo Augusto Thiel, a multifaceted German priest, did not restrict himself solely to his demanding ecclesiastic activities, but also became involved in issues related to ethnography, linguistics, anthropology, history and demography. This paper reveals that he was also interested in biological sciences, as is shown in a myriad of notes regarding flora and fauna, in field accounts written during his evangelization journeys through indigenous territories. In addition, he kept a collection of archaeological objects and birds, including Iridophanes pulcherrimus aureinucha, collected in Ecuador and later described as a new subspecies to science. Finally, he promoted actions for developing a botanical snake antivenom, and vehemently expressed concerns about deforestation that was already taking place in Costa Rica.
\end{abstract}

Keywords: flora; fauna; birds; indigenous territories; snake antivenom; deforestation; Costa Rica 


\section{Introducción}

La figura del sacerdote alemán Bernardo Augusto Thiel Hoffmann, segundo obispo en la historia de Costa Rica, así como Benemérito de la Patria desde 1921, fue una de las más prominentes de nuestra sociedad en la segunda mitad del siglo XIX; como una curiosidad, vivió exactamente ese medio siglo, pues nació en 1850 y murió en 1901. Establecido primero en Ecuador, donde residió desde 1874, tras una época de gran turbulencia política -lo que desató la persecución a la Iglesia católica- Thiel arribó a Costa Rica a fines de 1877 o inicios de 1878 (Sanabria, 1941). Primero fue profesor del recién fundado Colegio Seminario y, cuando frisaba los 30 años de edad, se convertiría en obispo nuestro, mandato que ejerció desde febrero de 1880 hasta su muerte; fue el sucesor de Anselmo Llorente y Lafuente, tras una vacante de un decenio.

Por fortuna, su vida y sus aportes han sido recuperados y sistematizados a lo largo de nuestra historia. Primero lo hizo Sanabria (1941), su principal biógrafo, mientras que, gracias a la existencia de su correspondencia y otros documentos en el Archivo Histórico Arquidiocesano Monseñor Bernardo Augusto Thiel (AHABAT), en años recientes otros autores han efectuado muy valiosas compilaciones (Zeledón, 2003; Herrera, 2009; Rojas y Sandí, 2011).

Asimismo, cabe destacar que, a manera de introducción, en Zeledón (2003) se recopilan muy valiosas síntesis, desde diferentes ópticas y disciplinas, escritas por los intelectuales Norma Loaiza Gutiérrez, Ricardo Blanco Segura, Luis Demetrio Tinoco Castro y Luis Ferrero Acosta. En ellas, al igual que en Sanabria (1941), se capta que a Thiel, quien era un auténtico erudito, todo o casi todo le resultaba de interés, pero no solo dejó un abundante testimonio escrito de ello, sino que también se involucró con fervor en actividades muy disímiles. Cuesta imaginar cómo le alcanzaban el tiempo y la energía para acometer tantas y tan variadas actividades, al punto de que, polifacético y de gran brillo intelectual, ha sido catalogado como evangelizador, etnógrafo, lingüista, antropólogo, historiador, demógrafo y hasta bibliófilo, pues tuvo una impresionante biblioteca personal, con más de 7000 tomos.

Sin embargo, hay una dimensión de Thiel muy poco conocida, y es su relación con las ciencias naturales, a lo cual dedicamos unos pocos párrafos en Hilje (2013). Ahora, en el presente artículo, se amplía el análisis de sus contribuciones en este campo, como una manera de profundizar y entender de manera más integral los aportes de este auténtico enciclopedista. 
Revista Herencia, Vol. 33 (2), julio-diciembre, 2020.

Figura 1. Monseñor Thiel, posando para Harrison N. Rudd.

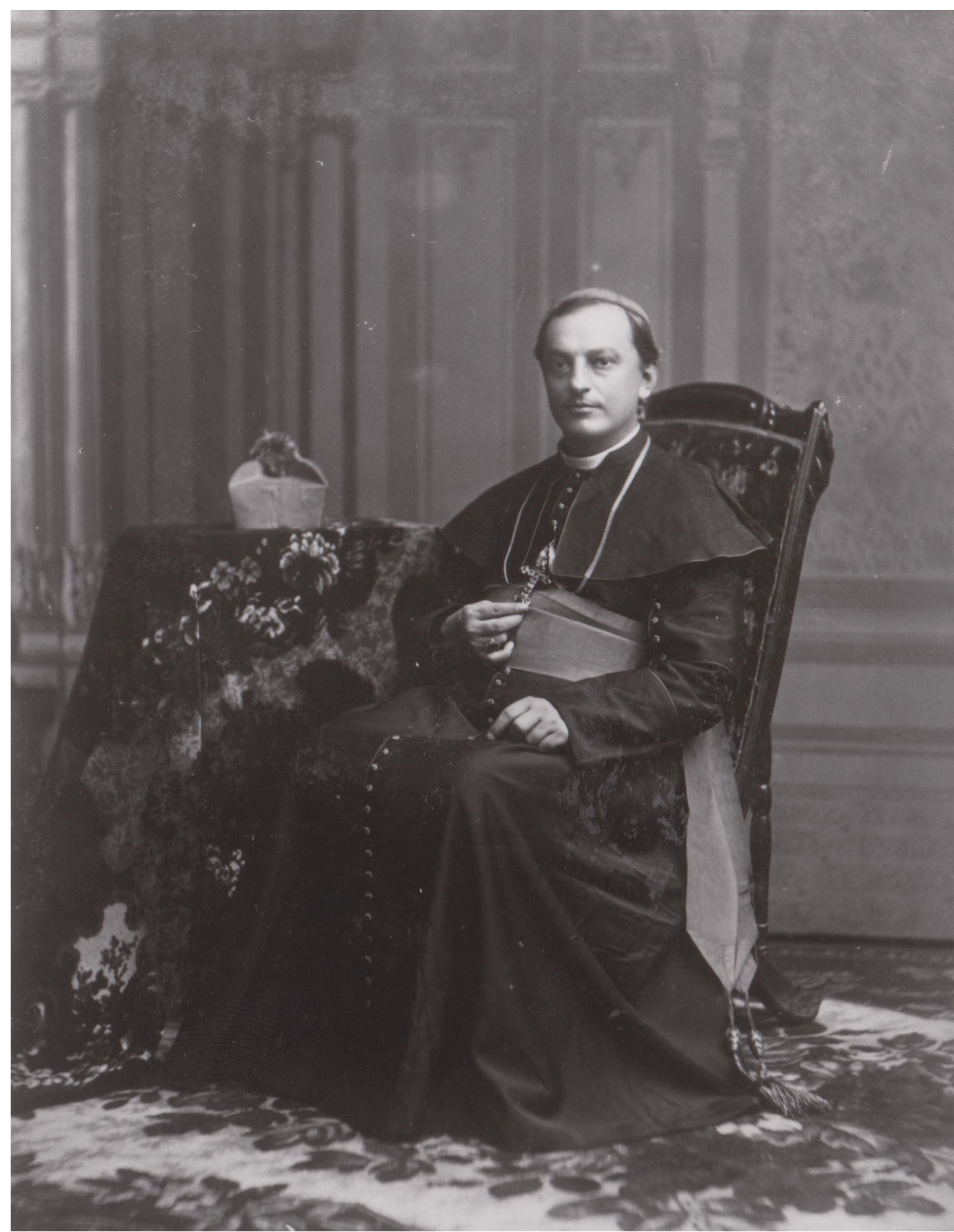




\section{Infatigable peregrino y cronista}

Cabe indicar que ninguno de los naturalistas que exploraron el país antes del arribo de Thiel (Figura 1) pudo recorrer el país con tanta amplitud como lo hizo él; así se visualiza en cuatro detallados mapas elaborados por Herrera (2009). Ellos fueron el austríaco Emanuel von Friedrichsthal, el danés Anders S. Oersted y el polaco Josef von Warszewicz, así como los alemanes Moritz Wagner, Karl Hoffmann, Alexander von Frantzius, Julián Carmiol, Hermann Wendland, Otto Kuntze y Helmuth Polakowsky, más el alsaciano Auguste R. Endrés (Hilje, 2013). Estos naturalistas no lo hicieron, por diferentes motivos y circunstancias, pero la convicción evangelizadora de Thiel era sumamente motivadora y poderosa, y lo llevó a peregrinar por toda nuestra geografía.

Debe destacarse que él no fue un obispo de gabinete y escritorio, sino que, infatigable y tenaz, durante los 20 años que ejerció el obispado transitó a pie o a caballo por veredas y llanos rurales, vadeó riachuelos y ríos, y escaló por escabrosos trillos de montaña, demostrando su fortaleza y reciedumbre ante inclementes soles y desmesuradas lluvias, picaduras de mosquitos, zancudos y otras alimañas, así como los riesgos de toparse con serpientes, cocodrilos y felinos.

Igualmente meritorio fue que siempre escribió detallados relatos de sus viajes, en los que incluyó todo cuanto le parecía importante de las comunidades visitadas. En tal sentido, actuó como un cronista de la cotidianidad de una gran parte de Costa Rica, al ser testigo presencial de actividades, costumbres, actitudes, opiniones y hasta aspectos mitológicos de la relación de los pobladores rurales -especialmente los indígenas- con el mundo natural.

Ahora bien, cabe aclarar que aunque la mayor parte de sus crónicas provienen de su propia mano, muchas fueron escritas por cercanos colaboradores que lo acompañaban en sus giras. Según Herrera (2009), entre ellos estaban Francisco Vargas, quien fungía como escribano de la Curia, así como los sacerdotes José Badilla Cordero, Jerónimo Martín Fernández, José Piñeiro, Alejandro Porras, Yanuario Quesada Madriz, Moisés Ramírez Castro y David Vargas Valenciano, más el diácono Federico Carvajal. Sin embargo, como Thiel siempre las revisaba y editaba, por lo que de una u otra manera todas tienen su impronta, para los fines de este artículo las atribuimos a él. 


\title{
Inmerso en el mundo tropical
}

\section{De paisajes y adversidades}

Para empezar, conviene incluir aquí algunos párrafos selectos, pues son muchos los que hay en la muy voluminosa obra de Herrera (2009), que incluye los libros de visitas canónicas, así como abundante correspondencia y otros textos de Thiel o sus colaboradores. Se trata de párrafos alusivos a las travesías por nuestro territorio -escritos o no por él, como recién se indicó-, en los que se perciben no solo los rasgos fisiográficos y la geografía humana de numerosos entornos, sino que también las inevitables adversidades y penurias que son inherentes a toda aventura exploratoria en el agreste mundo tropical. En todo caso, en estos textos no se percibe que fueran escritos para expresar quejas o lamentos, sino tan solo como una descripción de lo acontecido.

Por ejemplo, a fines de febrero de 1896, al viajar desde Guanacaste hacia la región del norte del país, Thiel expresaba lo siguiente:

\begin{abstract}
"Pasamos por última vez el Santa Rosa y algunas quebradas que mandan sus aguas al Santa Rosa. Al otro lado de la cima encontramos las quebradas de Las Lajas, Cien Pesos, Ayotes, Tronadora, Danta y Tronadorcita que mandan sus aguas a la laguna de las Cañas o Toroján [Tronadora]. A doscientas varas de la laguna tuvimos que hacer alto porque el terreno estaba inundado, nos quitamos zapatos y medias y fuimos por el agua hasta la orilla de la desembocadura de la laguna que es el origen del río Arenal. Llegamos como a las 4.30 p.m. Se arregló una balsa y como a las 6 p.m. comenzamos a pasar el desaguadero. Todos nos mojamos en la pasada, porque la balsa era mala. A las 8 p.m. al favor de la llena se concluyó el traslado de todo. Al otro lado encontramos un rancho, se hizo fuego con mucha dificultad. Comimos algo y nos acomodamos, algunos en el rancho, otros al pie de un árbol. En la noche nos llovió una hora".
\end{abstract}

Asimismo, siempre en esas fechas y en dicha región, ya en San Carlos o Upala, manifestaba que

"cesó la lluvia por fin y coloró el alba con una luz brillante el limbo de los cielos. Día fue ayer sombrío y aguado, pareciéndome aún verme sepultado en aquellas aguas profundas, cuyo solo recuerdo causábame escalofríos. Presurosos nos levantamos a tomar una taza de confortante café, y pocos momentos después las cargas estaban repartidas. Las bestias no podían servirnos más, por los precipicios y cuestas al través de serranías intransitables. Necesario era marchar a pie y así lo hicimos a las 8 a.m., atravesando los bosques llanos que siguen al río. Un carguero nos guía, cortando con su afilado cuchillo las espinas y ramas que impiden el paso. Subimos montañas al noreste, agarrándonos de las ramas y raíces de los árboles, poniendo nuestra planta allí donde solo se atreven los huleros contrabandistas o el indio incivilizado, y bajamos pendientes en cuyo fondo se oye el confuso rumor del torrente que se precipita". 
Conviene hacer una digresión para indicar que las alusiones a los huleros son reiterativas a lo largo de su crónica referida a las llanuras del norte del país. Estos individuos, provenientes de Nicaragua, causaron problemas recurrentes a lo largo de nuestra historia, pues extraían un recurso natural perteneciente a Costa Rica, además de que solían vejar a los indígenas malekus o guatusos que habitaban esas tierras.

Al respecto, es más que elocuente el siguiente testimonio de Thiel:

"Uno de los indios nos contó los grandes trabajos que pasaban todos por los maltratamientos de los huleros, que a él un hulero le había matado a su padre. Que su padre estaba cortando un árbol de hule del platanar que le pertenecía, con el fin de hacer de la corteza un vestido, cuando uno de los huleros se acercó secretamente y le partió de un machetazo la cabeza. Que todos se veían obligados a huir al monte al acercarse los huleros, dejando sus casas y sus provisiones, y viviendo de raíces, de palmitos y pacayas. Que los huleros les habían robado muchísimos niños; que además muchos niños habían muerto en la montaña huyendo de los huleros y habían sido devorados los unos por los tigres, y otros habían muerto mordidos de culebras. Que además muchos hombres y mujeres ya grandes, habían muerto a consecuencia de las enfermedades que habían contraído cuando estaban obligados a vivir en el monte durante los meses de lluvia, sin ranchos y sin comida".

Es oportuno acotar que, a diferencia del hule o caucho (Hevea brasiliensis), que es suramericano y de la familia Euphorbiaceae, nuestro árbol de hule o goma elástica (Castilla elastica) pertenece a la familia Moraceae, la misma de los higuerones. Su savia o látex es de inferior calidad que la primera especie (León y Poveda, 2000) pero, aún así, los indígenas la secaban y la utilizaban para impermeabilizar telas, sandalias y otros objetos. En cuanto a las otras plantas y animales citados, los respectivos comentarios de nuestra parte aparecen en las secciones referidas a la flora y la fauna documentada por Thiel.

Ahora bien, en otra oportunidad, en abril de 1892 y cerca de la frontera sur de Costa Rica, Thiel expresaría que

\footnotetext{
"la noche se nos vino encima, pero la luna en su primer cuarto nos prestó su luz apacible durante un buen rato. Y era preciso caminar. Según el programa aprobado debíamos hacer noche al otro lado de Barú, y era forzoso pasarlo antes de la pleamar o perder media jornada. Transidos de sed y fatigados de la marcha, llegamos un poco antes de medianoche a la boca del Barú, al tiempo que la marea crecía con violencia, y con gran riesgo pudimos vadear el anchuroso estero, de modo que tres viceítas que se tardaron algo, debieron quedarse del opuesto lado. Pasamos, pues, y acampamos en un banco de arena. Solo pudimos tomar un bocado de pan y tendernos rendidos de sueñoy de cansancio".
} 
Cabe indicar que, según la antropóloga María Eugenia Bozzoli, los viceítas aquí citados corresponden a una etnia también conocida en antiguos documentos como viceitas, viceytas, bisaitas y biseytas, pero que corresponden a los actuales bribris, residentes en la región de Talamanca. Este grupo indígena fue visitado varias veces por Thiel, de lo cual quedó un vívido testimonio pictórico en dos imágenes trazadas por el intelectual José María Figueroa Oreamuno, quien lo incluyó en varios pasajes del célebre Álbum de Figueroa, junto con alguna otra información acerca de él. Figueroa lo conoció bien, y hasta lo acompañó en algunas giras, a pesar de no ser religioso, sino más bien un individuo bastante irreverente, muy crítico de todos los convencionalismos de la época.

Para retornar a algunas de las vicisitudes enfrentadas durante las visitas pastorales, siempre al sur del país, Thiel anotaba que

"a las 11 comenzó a llover de nuevo, el camino se hizo casi intransitable, nos perdimos en un platanillar inmenso, de donde salimos con mucho trabajo; al llegar al río Coén -tributario de La Estrella- encontramos el río salido de su cauce. No era posible pasarle en el paso ordinario y hubo que subir aguas arriba para encontrar un lugar en donde se podría botar un palo. Después de muchos tanteos en que perdimos como hora y media, encontramos finalmente un lugar favorable en donde el río se dividía en dos brazos. Los indios nos pasaron en hombros, formando hileras de 8 y apoyándose en grandes bastones. Seguimos caminando hasta llegar a Moiñoc (embocadura del Moín en La Estrella) en donde encontramos un palenque caído".

Por último, en las crónicas aparece una vívida imagen, de gran plasticidad, referida al paisaje típico de las planicies de Guanacaste en la estación seca. Dice así:

"Al principio, dadas las circunstancias de la hermosa tarde de la llanura del camino, hubimos de precisar el paso, antes de que cayera la noche. La tarde comenzaba a apagarse al presentársenos una pequeña cuesta pendiente y oscura que subimos con no poco trabajo. Serían las 8 de la noche cuando arribamos a una casa situada en lo más solitario del camino y allí tomamos un poco de agua para refrigerar un tanto la sed causada casi siempre por las fatigas del viaje y los fuertes calores de aquellos contornos. Ya nos faltaba una legua de camino para llegar a la Provincia. Proseguimos sin más detención por aquellas llanuras que pronto volvieron a reaparecer. La noche se ostentaba serena y silenciosa, la bóveda del cielo, azul y transparente, lucía toda la brillantez de su ropaje nocturno de verano. Las arboledas y enramadas secas estaban igualmente silenciosas, la brisa no movía sus ramajes ni aleteaba un ave en ellos, ningún viajero nos daba alcance y a ninguno topábamos en el camino". 


\section{Respetuoso de los científicos}

Un párrafo análogo al anterior, de naturaleza bastante lírica, alude al paisaje y la fauna de un paraje talamanqueño. Fue escrito por uno de sus colaboradores, y dice así:

“Este lugar de Bitey es hermoso, está sobre el río Bitey en una altiplanicie de media milla. Todo es hermoso allí, infinidad de pájaros de los más variados colores que en ninguna parte. Colibríes preciosos, entre los que admiré uno de cinco pulgadas, perfectamente negro y las puntas de la cola blancas. Un carpintero canelo con la cresta blanca, y por todos lados la sonriente naturaleza. Enfrente de nosotros se divisaba el azul de las montañas de La Estrella, a nuestros pies un río pequeño -el Bitey- serpenteando en medio de un desierto potrero de zacate, de cien manzanas lo menos, orillado por fértiles patriotales. Pero ¡oh desgracia!, el clima era de lo más malsano de la república. De medianoche al día, era tal el aire húmedo, que todo se mojaba y un desnivel en la temperatura muy rápido. Todos nos enfermamos, el señor Obispo [Thiel] se puso ronco, el pobre señor Lyon seguía casi sin conocimiento, los indios acatarrados y el doctor Bovallius y yo, con un temblor convulsivo. Vimos claro que un día más de permanencia allí sería fatal para todos".

En cuanto al individuo apellidado Lyon, se trataba del marino estadounidense John H. Lyon, llegado a Talamanca en 1858, donde se casó con una princesa bribri llamada Gregoria, con la cual procreó varios hijos; en 1867 el gobierno lo nombró Secretario y Director de Reducciones en Talamanca, es decir, una especie de árbitro en conflictos entre jefes indígenas (Ferrero, 1978). Por cierto, entre 1873 y 1875 se realizó una gran exploración de esa región, promovida por el empresario ferrocarrilero Minor C. Keith junto con el gobierno del general Tomás Guardia Gutiérrez, aunque después la asumió nuestro país por completo. Se contrató como líder al geólogo y etnógrafo estadounidense William M. Gabb, quien con Florencia -hermana de Gregoria- procrearía a Guillermo Gabb Lyon, quien sería educado en la capital, para después convertirse en maestro de primaria, traductor y colaborador con varios etnógrafos y científicos; su segundo apellido proviene de que su tía había adoptado el apellido del esposo, y entonces su hermana Florencia también lo usaba.

Por cierto, en una de las crónicas de Thiel se indica que, tras cruzar el río Coén,

"ya en la otra orilla todos continuamos nuestro viaje hasta un rancho, donde descansó el malogrado doctor Gabb y sufrió tres días una calentura -hace algunos años- cuando hacía su viaje de exploración a Talamanca. Según se nos dijo, una anciana que allí se encontraba, era la misma que a él le cuidó y el rancho estaba en la misma disposición que entonces". 
Estos síntomas sugieren que, cuando esto sucedió, Gabb ya había sido infectado por una de las cuatro especies de protozoarios que causan la malaria o paludismo -quizás Plasmodium falciparum o P. vivax-, transmitido por el zancudo Anopheles albimanus, al igual que les sucedió a otros de sus compañeros de aventura; él moriría en 1878, ya de regreso a su patria, debido a esta enfermedad.

Ahora bien, en relación con las aves observadas en Bitey, según el ornitólogo Luis Sandoval, el colibrí es un macho de Campylopterus hemileucurus; aunque no es negro, sino morado, la percepción errónea podría haber obedecido a la falta de luz y, ciertamente, destacan las plumas blancas de la punta de la cola. En cuanto al carpintero, pareciera ser Celeus castaneus; si bien su cresta no es blanca, es prominente $y$, dependiendo de la luz, podría percibirse como color crema.

Cabe destacar que el párrafo recién transcrito proviene del viaje que en el segundo semestre de 1882 efectuara al Caribe el arqueólogo sueco Carl Bovallius (Figura 2A), de visita a Costa Rica junto con el botánico austríaco Anton Hübsch. A su comitiva se sumaron dos respetados alemanes residentes en el país, el naturalista Julián Carmiol Grasneck (Figura 2B) y el comerciante Guillermo Steinvorth Ulex, pero tan solo hasta la hacienda Caño Seco, en las cercanías de Siquirres, la cual pertenecía a sus coterráneos George Müllner y Gottlieb Schäfer (Hilje, 2013).

Figura 2. Los naturalistas Bovallius (A) y Carmiol (B).

A.

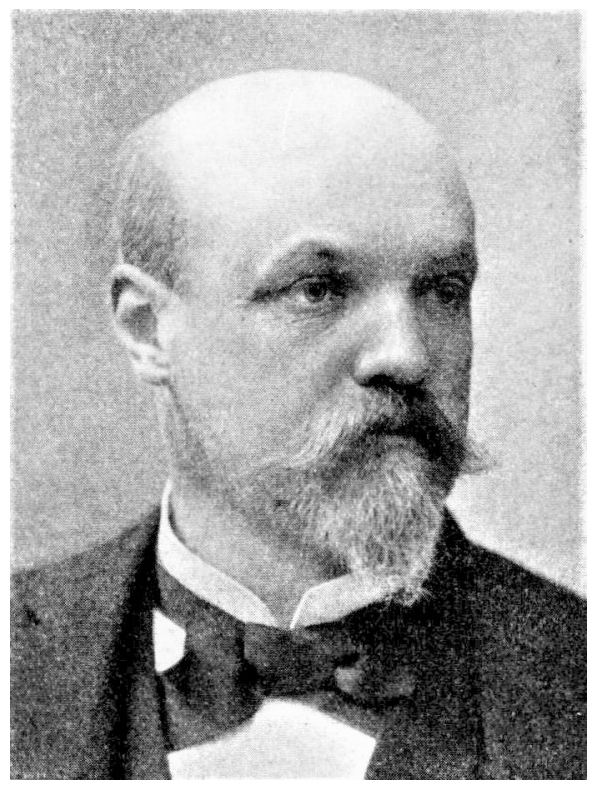

B.

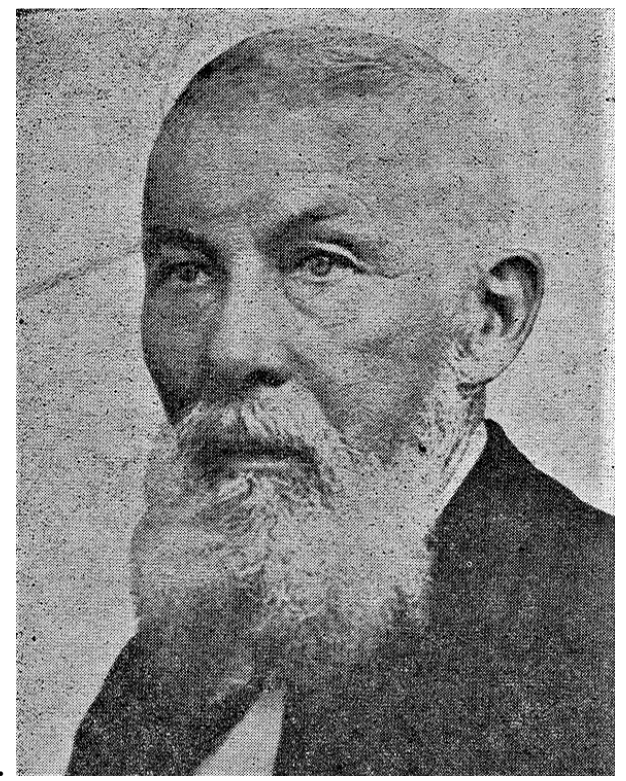


Acerca de esta gira, Bovallius expresa que, mientras permanecía en Caño Seco, tuvo la intención de viajar a la desembocadura del río Parismina para capturar al legendario manatí (Trichechus manatus), pero

\footnotetext{
"esta excursión que tanto prometía no se realizó nunca, porque una carta de mi amigo Herr Hübsch, quien un par de semanas antes ya había regresado a San José, cambió enteramente mis proyectos de caza. Contenía efectivamente una llamada del Obispo de Costa Rica, el Dr. Bernardo Augusto Thiel, para que lo acompañara en un viaje de misiones en Talamanca, una región poco conocida desde el punto de vista geográfico y etnográfico, y nunca visitada antes por un zoólogo o botánico. Era una llamada demasiado tentadora para rehusarla: pero como no podía dejar mis valiosas colecciones en Caño Seco abandonadas, llegué a un acuerdo con el Obispo de llegar dos días más tarde" (Bovallius, 1887).
}

De manera implícita, esta afirmación denota cuánto disfrutaba Thiel de la compañía y el intercambio de conocimientos con científicos, y sobre todo de la talla de Bovallius y Hübsch, casi un premio en la anodina Costa Rica de entonces.

Ahora bien, siempre en cuanto a la relación de Thiel con los científicos, para la época en que llegaron Bovallius y Hübsch, había apenas dos naturalistas, el ya citado Carmiol y José Cástulo Zeledón Porras, formado en el Instituto Smithsoniano, en Washington, y a quien se aludirá con más detalle posteriormente. Pocos años después surgirían los naturalistas Anastasio Alfaro González y José Fidel Tristán Fernández, graduados en el Instituto Nacional y el Liceo de Costa Rica, respectivamente, los cuales carecían de una base científica sólida, pues eran entes de enseñanza secundaria.

Es decir, con excepción de Zeledón, de quien fue buen amigo, Thiel no tenía con quién conversar de ciencia y, sobre todo, de cuestiones filosóficas profundas, como el conflicto entre la fe y la razón, que son los cimientos de la religión y la ciencia, respectivamente. Esto último es de gran importancia, pues en casi toda América Latina habían tomado gran auge las ideas liberales, con fuertes implicaciones en los planos político, social, cultural y religioso. Basados en una noción filosófica positivista -alejada de la religión y la magia-, sus practicantes consideraban que solo mediante la razón y la ciencia era posible adquirir el conocimiento necesario para comprender las leyes de la naturaleza y así poder dominarla y transformarla, para beneficio de la humanidad. 
Por tanto, los gobiernos liberales de Guardia (1870-1876, 1877-1882), Próspero Fernández Oreamuno (1882-1885) y Bernardo Soto Alfaro (1885-1890), y sobre todo los dos últimos, dieron un fuerte impulso a la ciencia y la tecnología, lo que implicó reformar de manera sustancial el sistema educacional, históricamente muy influenciado por la muy poderosa y omnipresente Iglesia católica. El conflicto, documentado en forma detallada por varios autores (Blanco, 1984; Salazar, 2002; Díaz, 2007), alcanzó tal nivel de tirantez que, en el gobierno de Fernández Oreamuno, culminó con la emisión de leyes anti-clericales, como la conversión de la educación en laica, la secularización de los cementerios y la proscripción de las órdenes religiosas.

En el caso de Thiel, en julio de 1884 fue expulsado del país junto con un importante grupo de jesuitas. Ellos viajaron por la calzada empedrada que culminaba en el poblado de Carrillo -inaugurado dos años antes, el 7 de mayo de 1882-, a través de los densos bosques del Bajo de La Hondura, para tomar el tren que los llevó a Puerto Limón. Erigido en marzo de 1957 dentro de una rústica ermita -bastante deteriorada hoy, debido a la intemperie y al vandalismo-, aún se yergue un monumento conmemorativo de ese doloroso viaje hacia el exilio (Figura 3). En esa especie de hito-altar, de unos $4 \mathrm{~m}$ de altura, una placa de mármol contiene la siguiente inscripción: "En memoria del obispo Monseñor Augusto Thiel, que el 18 julio 1884 pasó por aquí hacia el destierro. Moravia 31 marzo 1957".

Ahora bien, en congruencia con sus planteamientos, los impulsores del liberalismo decidieron fortalecer de manera robusta las entidades de enseñanza secundaria, y fue así como se propusieron reclutar docentes de alto nivel en Europa (Conejo, 1975). En consecuencia, arribaron al país varios profesores suizos, entre los que destacaron tres naturalistas: el geógrafo y botánico Henri Pittier Dormond, el zoólogo Paul Biolley Matthey y el botánico Adolphe Tonduz Berthoud. Tiempo después, pero por otras vías, motivos y circunstancias, a ellos se les sumarían el botánico alsaciano Carlos Wercklé Deher, el estadounidense George K. Cherrie y el inglés Cecil Underwood Dodd, zoólogos los dos últimos (Hilje, 2013). Mucho antes, entre 1875 y 1876, había residido en el país el botánico alemán Helmuth Polakowsky Schmidt. 
Figura 3. El autor, al lado del monumento a Thiel.

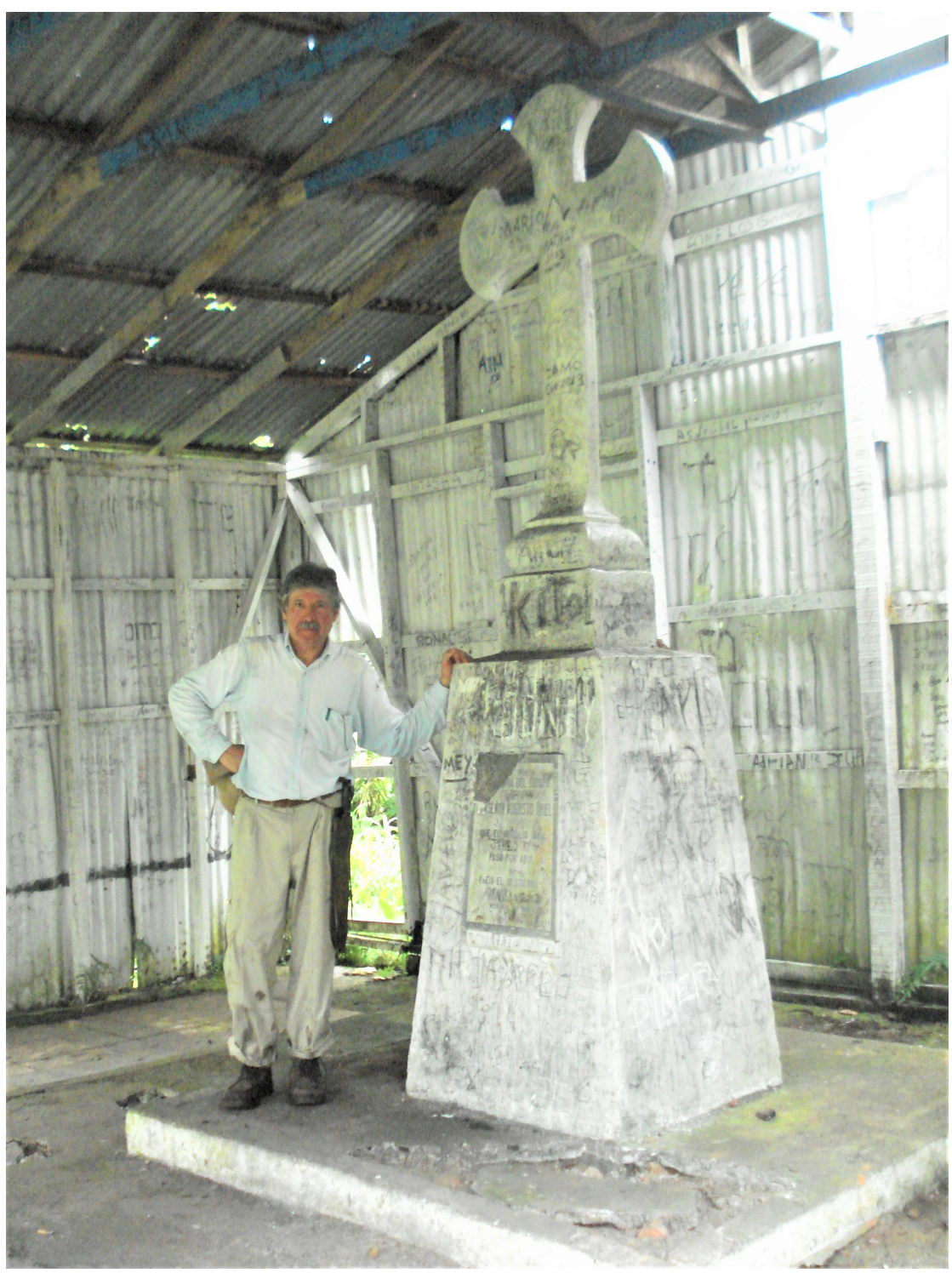

Es de resaltar que a Thiel se le permitió retornar al país, lo cual ocurrió en mayo de 1886. Asimismo, en enero de ese año había llegado a nuestras costas Biolley, mientras que Pittier lo haría en noviembre de 1887. Y, aunque a primera vista se podría pensar que, por su condición de científicos y por estar apadrinados por los liberales, ellos antagonizarían con Thiel o éste con ellos, no ocurrió así. Por el contrario, hombres de agudo intelecto y mente amplia, Thiel y Pittier desarrollaron una respetuosa relación personal y profesional, sobre la cual es muy difícil profundizar, pues entre ellos hubo escasa correspondencia; de hecho, en el AHABAT hay apenas seis cartas de Pittier a él. 
Una irrefutable evidencia de esta relación de colaboración mutua es que Pittier valoraba tanto la obra escrita de Thiel que, en su condición de director de dicha entidad, hizo publicar en los Anales del Instituto Físico-Geográfico Nacional varias de las crónicas del obispo (Herrera, 2009). En tal sentido, también es reveladora la siguiente noticia, aparecida en el Eco Católico en junio de 1900:

"Sabemos que trabajos muy importantes sobre cartas geográficas de Talamanca está llevando a cabo el ilustrísimo señor Obispo con datos que le ha enviado el señor misionero de aquel lugar, presbítero don Agustín Blessing. En esos trabajos coadyuva Mr. Henry Pittier. Por motivo de la cuestión límites con Colombia, esos trabajos revisten particular interés".

Además, en otra oportunidad, que data de 1895, José Victoriano Mayorga, cura de la localidad, expresaba que

\begin{abstract}
"al fin, después de cinco meses logré que el Supremo Gobierno de la República, se resolviera favorable para abrir un camino formal, que partiendo desde "La Uvita", ponga en comunicación, por tierra con los pueblos de Buenos Aires, Térraba y Boruca; la obra será magna y dará a la nación y a la industria, ensanche fabuloso. El Gobierno también ha tenido perfecta confianza y me ha designado para desempeñar el honroso encargo de dirigir la empresa, poniendo a mi orden todo lo necesario al objeto. El martes próximo partiré de esta capital para Puntarenas y de allí me embarcaré para "La Uvita": allí saltaré a tierra para esperar y reunirme con Mr. Henry Pittier y juntos seguidamente haremos la picada, hasta llegar al punto de ramificación con los tres pueblos".
\end{abstract}

Es de suponer que la cordial relación entre Thiel y Pittier (Figura 4A), también favorecida por el interés común en la etnografía y la lexicografía de los lenguajes indígenas, se mantuvo durante los casi 13 años que compartieron en Costa Rica, segada por el fallecimiento del primero, en 1901. Pittier permaneció en el país tres años más, pues a fines de 1904 partió hacia EE.UU., donde laboró por casi 14 años en el Departamento de Agricultura (USDA), tras lo cual se instaló en Venezuela, donde murió (Conejo, 1975).

Ahora bien, en cuanto al botánico alemán Polakowsky (Figura 4B), la situación fue muy curiosa, pues ellos no se conocieron en persona. De hecho, en una carta fechada el 7 de setiembre de 1883 y dirigida al reputado historiador León Fernández Bonilla, Thiel le dice lo siguiente: "Le envío la inclusa hoja que así me llegó por el correo de ayer, que contiene una traducción de una parte de sus Documentos, hecha por un señor Polakowsky que debe haber sido profesor en el Instituto Nacional" (Herrera, 2009); cabe acotar que Thiel se refiere a la célebre Colección de documentos para la historia de Costa Rica. Nótese que Thiel sabía poco de Polakowsky quien, en efecto, llegó a Costa Rica en 1875, contratado como profesor del Instituto Nacional, un novedoso ente de educación secundaria establecido durante el primer gobierno del general Guardia. 
Figura 4. Los naturalistas Pittier (A) y Polakowsky (B).
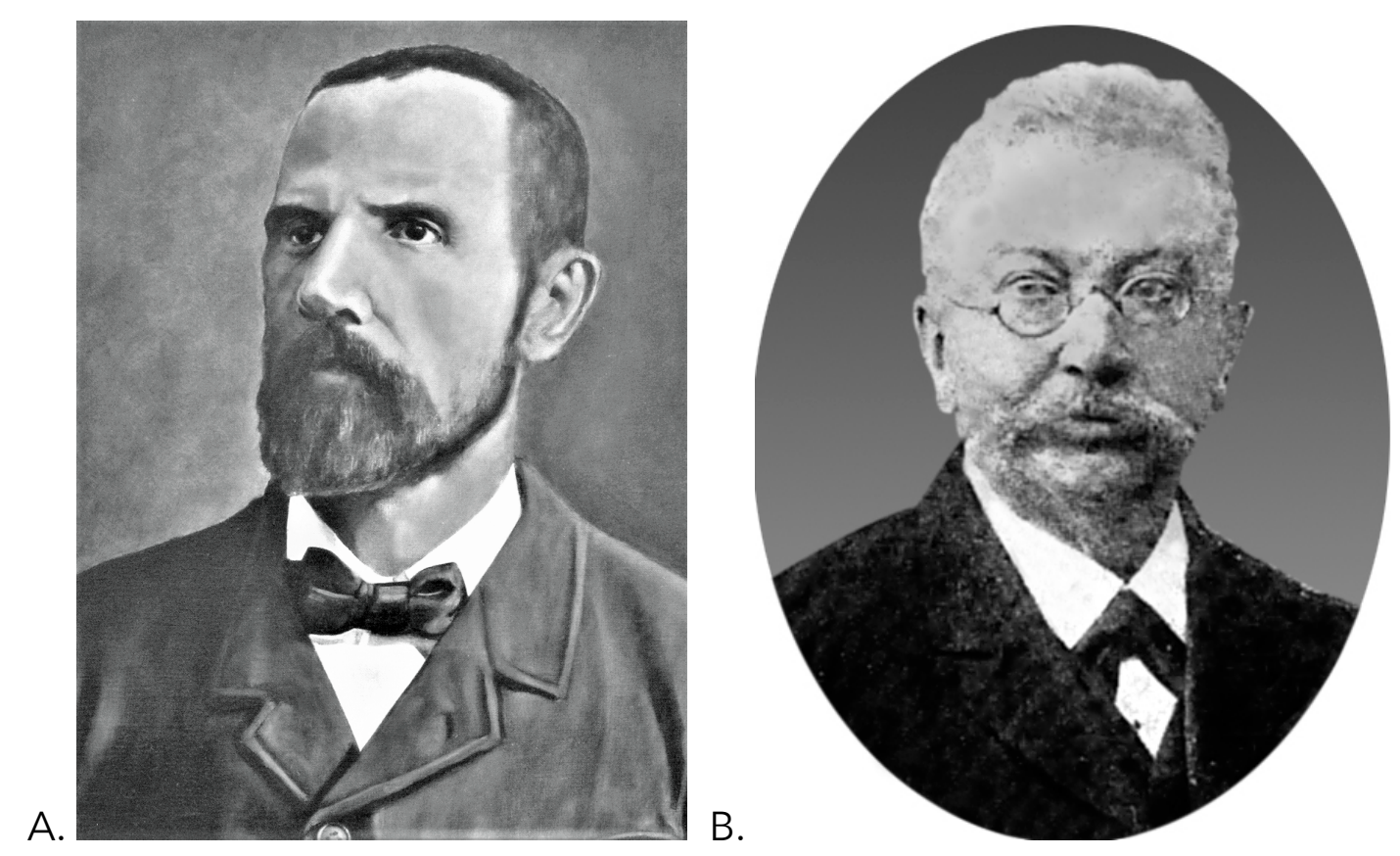

La relación entre Thiel y Polakowsky se percibe en siete cartas remitidas por éste desde Berlín, las cuales están depositadas en el AHABAT, y clasificadas por libro (I.), tomo (t.) y folios (f.). Comprenden dos fechadas en 1884 (I. 276, t. 1, f. 321 322 y 337-338), dos en 1888 (I. 276, t. 1, f. 71-72 y 128-129), dos en 1893 (I. 403, t. 1 , f. 43 y 166) y una en 1894 (I. 403, t. 1, f. 255-257). Sin embargo, no se refieren a cuestiones etnobotánicas -con un par de excepciones, que se discutirán después-, como hubiera podido esperarse, sino a arqueología, campo en el que incursionó este botánico, al igual que en otros más. De ello da fe el artículo Altertümer aus Costa Rica (Antigüedades de Costa Rica), publicado en 1888 y traducido al español dos años después (Polakowsky, 1890); apareció en un libro intitulado Festschrift zur Jubelfeier des 25 jährigen Bestehens des Vereins für Erdkunde zu Dresden (Escrito en conmemoración del jubileo de los 25 años de existencia de la Asociación Geográfica de Dresde).

En el artículo Antigüedades de Costa Rica menciona varias veces a Thiel, de quien dice que en 1881 y 1884 le envió valiosos datos para tres artículos suyos. El primero, que data de 1883, era Der Bischof von Costa Rica bei den GuatusosIndianern am Río Frío (El Obispo de Costa Rica donde los Indios Guatusos del Río Frío). El segundo, también de 1883, era Der Bischof von Costa Rica bei den Chirripó-Indianern (El Obispo de Costa Rica donde los Indios del Chirripó). 
El tercero, de 1885, correspondía a Die neuesten Reisen zur Durchforschung von Costarica (Los viajes más recientes de exploración de Costa Rica). El primero fue publicado en la revista Sonntagsblatt der Vossischen Zeitung, mientras que los otros dos aparecieron en Petermanns Geographische Mittheilungen.

Cabe acotar que, en su artículo, Polakowsky se refiere a una colección de objetos arqueológicos que era propiedad de Thiel, e indica que "la mayor parte de ella se compone de armas y utensilios domésticos de los guatusos, y de objetos de piedra y de oro procedentes de la península de Nicoya". Esa colección -que desde 2016 está depositada en el Museo Nacional- fue muy famosa, al punto de que incluso recibió una importante distinción. En efecto, en una carta fechada el 27 de diciembre de 1892 en Madrid, Manuel María Peralta Alfaro, ministro plenipotenciario de Costa Rica en Europa, le comunicaba que "el Jurado de recompensas de la Exposición Histórico Americana de Madrid ha concedido a U., una medalla de oro por su preciosa colección de antigüedades de los Cotos, Borucas, Güetares y Chorotegas" (AHABAT, I. 403, t. 1, f. 13-13v). Dicha exhibición se efectuó para conmemorar el cuarto centenario del descubrimiento de América.

Es oportuno indicar que la colección de Thiel correspondió a una muestra de 18 figuras de oro, entre ellas varias zoomorfas (águilas, otras aves, sapos, ranas y un cuadrúpedo), al igual que algunos objetos de piedra, calificados como "los ejemplares más valiosos de toda la colección, tanto por su tamaño como por el gran interés histórico que encierran", más varios utensilios de barro (Anónimo, 1893). Para los fines del presente artículo, cabe destacar que en la categoría de "instrumentos y objetos varios" había

\footnotetext{
"tres tambores, dos cerbatanas, dos bastones de cacique, 21 arcos y flechas, un cuchillo de madera, una bocina, varios utensilios para encender fuego, cuatro mazorcas diminutas de maíz de Guatuso, una piel de iguana, pita y una cuerda construida con ella, cuatro mantas bien tejidas y dibujadas, ocho mochilas y un mastate".
}

A algunos de estos materiales se hace referencia al analizar las crónicas de Thiel.

Una síntesis de su contenido data de 15 años después de su muerte, cuando se compiló la información para editar el célebre Libro azul, publicado por The Latin American Publicity Bureau, con el fin de promocionar a Costa Rica en el extranjero. Para entonces el obispo era el también alemán Juan Gaspar Stork Werth, quien le había destinado un amplio espacio al Museo Episcopal en las instalaciones del Seminario, localizado en el cuadrante detrás de la Catedral Metropolitana. 
Figura 5. Vista del interior del Museo Episcopal.

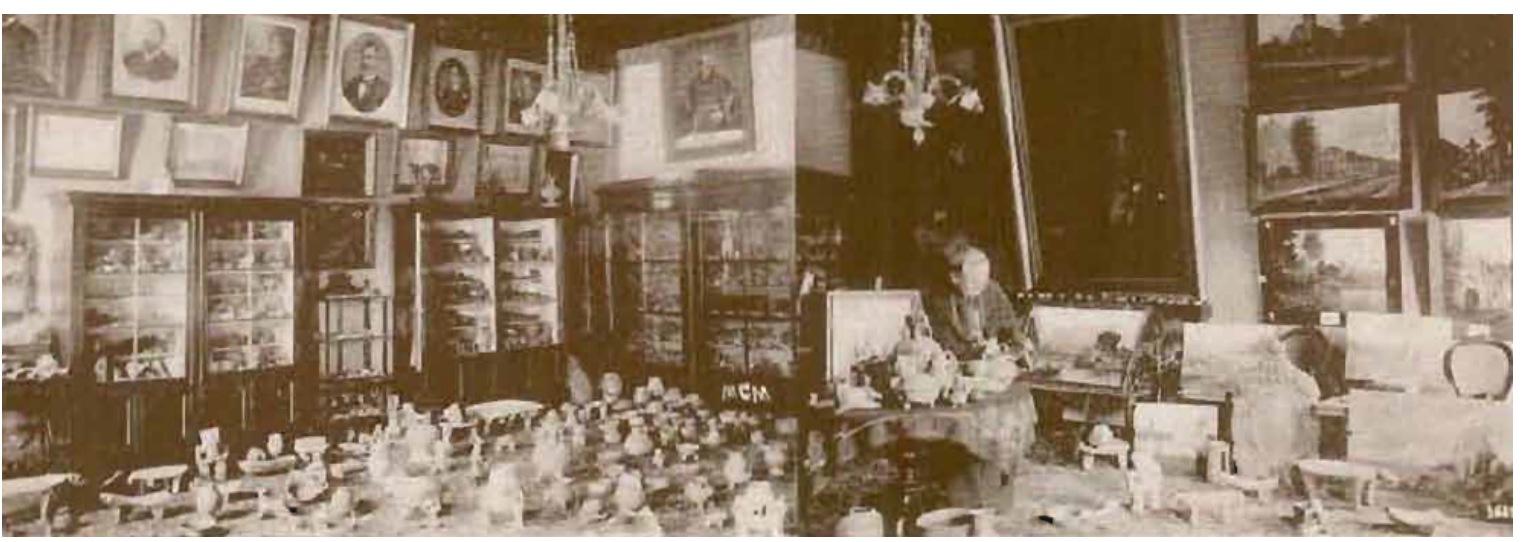

Fuente: Libro azul.

Su editor, J. Bascom Jones, consignó que, al morir Thiel, la colección

"constaba ya de unos 850 ejemplares, entre los que figuraban modelos de alfarería, piedra, símbolos de oro y 12 piedras verdes (collares y cuchillos de sacrificios humanos). En la actualidad consta de unos 6000 objetos indígenas, procedentes en su mayor parte del Guanacaste (Nicoya y Santa Cruz), Térraba, Boruca, El General, fal das del [volcán] Turrialba y Línea Vieja. Son dignas de mencionarse las colecciones de piedras verdes, de ídolos y de objetos de oro, todas muy numerosas, de incalculable valor histórico y artístico. Muy notable es también la colección de pájaros de Costa Rica y la de colibríes de Ecuador, colocadas ambas en espaciosas y elegantes vitrinas" (Jones, 1916).

A estos valiosos objetos se sumaban abundantes "camafeos, cuadros, pinturas y retratos", algunos de ellos descritos por el editor del libro.

Para concluir, esta sección, la interacción de Thiel con los científicos la resumió su biógrafo de la siguiente manera:

"Todos estos trabajos pusieron en comunicación al Prelado con eminentes hombres de ciencia, con quienes mantuvo frecuente correspondencia, especialmente con el ya citado Profesor Polakowsky, Alfonso Pinart, [Henri] Pittier, Carl Bovallius y otros. En esa correspondencia, especialmente con Polakowsky, fue comunicando sus nuevas observaciones de costumbres y etnología general de los indígenas, que iba anotando en los nuevos viajes a las respectivas regiones" (Sanabria, 1941). 
Sin embargo, la revisión de los legajos en el AHABAT indica que, en realidad, la correspondencia entre ellos no fue tan frecuente como lo sugiere esta afirmación. Por cierto, al arqueólogo Bovallius y al etnógrafo francés Pinart quien conoció de cerca y escribió sobre los aborígenes de varios países centroamericanos-, hay que sumar al etnólogo suizo Albert Samuel Gatschet, quien laboraba en el Instituto Smithsoniano; cabe destacar que, a mediados de agosto de 1884, recién desterrado y en ruta hacia Europa, Thiel visitó dicha entidad científica, en Washington. Asimismo, es interesante que la convergencia con los botánicos Polakowsky y Pittier no ocurriera en la especialidad de ellos, sino más bien en aspectos arqueológicos y etnográficos.

Finalmente, y a manera de síntesis en cuanto a la tolerancia y el respeto mutuos entre Thiel con los científicos, de su relación directa y algo prolongada con Pittier, pasajera con Bovallius y Hübsch, así como también extensa con los naturalistas costarricenses Zeledón, Alfaro y Tristán, se capta que siempre prevaleció una gran cordialidad, a pesar de que algunos de estos científicos -si no todos-, diferían de sus creencias y convicciones.

\section{Un libro de geografía frustrado}

Cabe destacar que, a mediados de setiembre de 1883, durante el gobierno del ya citado Fernández Oreamuno, surgió una interesante iniciativa científica. Estaba liderada por Pedro Porras Bolandi, profesor en el Instituto Nacional, que era un ente de secundaria albergado en las instalaciones de la Universidad de Santo Tomás. En efecto, él junto con tres jóvenes, presentó un proyecto a Bernardo Soto, por entonces ministro de Fomento, para la escritura de un texto sobre la geografía de Costa Rica. Esos jóvenes, que rondaban los 18 años de edad pero empezaban a descollar, eran Carlos Gagini Chavarría y Roberto Twight Dengo, más el recién citado Anastasio Alfaro.

El proyecto para elaborar el citado tratado de geografía, cuyo contenido no pudimos conocer, pues no aparece en el expediente respectivo en el Archivo Nacional (Congreso-8842), fue remitido el 18 de setiembre de 1883 por el ministro Soto al Congreso, donde se designó a Juan Manuel Carazo Peralta para que lo estudiara y vertiera un dictamen. Así lo hizo este diputado, y el 21 de octubre remitía a la Honorable Comisión Permanente su veredicto, que aparece en el citado expediente, así como en el diario oficial (La Gaceta, 7 de noviembre de 1883, No. 248, p. 1). El texto es el siguiente: 
Revista Herencia, Vol. 33 (2), julio-diciembre, 2020.

"El Diputado que suscribe, impuesto de la proposición presentada al Poder Ejecutivo por los Señores Don Pedro Porras, Don Carlos R. Gagini, Don Roberto Twight y Don Anastasio Alfaro, en memorial fecha 17 de setiembre último, tiene la honra de emitir su parecer en estos términos: Es innegable la necesidad que tiene el país de un tratado de Geografía en que no solamente se comprendan las comarcas conocidas, sino también las desconocidas, su suelo, su feracidad, producciones, etc., y en que se pueda adquirir el conocimiento de los minerales, maderas de construcción, modo de cultivar la vainilla y la quina, y de beneficiar el ámbar y extraer muchas gomas de que abunda el territorio de la República, y que más tarde podrán ser un venero de riqueza para la generalidad de sus habitantes. No puede negarse tampoco que en las regiones incultas del país, por el mismo hecho de ser casi desconocidas, hay necesidad de arbitrar los medios necesarios para su estudio y aprovechamiento futuro. Mas las circunstancias deficientes en que se encuentra el Tesoro Nacional, impiden por el momento la realización del plan propuesto; y por este motivo es de parecer que os sirváis manifestar al Poder Ejecutivo que, por ahora, conviene desestimar la propuesta indicada. Tal es la opinión del infrascrito, mas vos, con el acierto acostumbrado, resolveréis lo mejor".

\section{Fechada el 5 de noviembre de 1883 y suscrita por Leovigildo Castro Soto -en su condición de secretario de esta instancia legislativa-, en la resolución final dirigida al ministro Soto se expresaba lo siguiente:}

“La Honorable Comisión Permanente, por acuerdo consignado en el artículo $2^{\circ}$ del acta $34^{a}$ correspondiente a la sesión celebrada el día 31 de octubre próximo pasado, dispuso lo que sigue: Se leyó el dictamen emitido por el Honorable Señor Diputado Don Juan Manuel Carazo, acerca de la representación en que Don Pedro Porras, Don Carlos R. Gagini, Don Anastasio Alfaro y Don Roberto Twight proponen escribir una obra de Geografía de Costa Rica, con la de Fauna, Flora y Mineralogía de la misma, comprometiéndose a hacer un estudio detenido de las comarcas desconocidas y maderas de construcción, a presentar una rica colección de sus plantas medicinales, y datos ciertos sobre sus aplicaciones, lo mismo que sobre el cultivo de éstas y de la vainilla, sobre el modo de preparar la quina y de extraer el ámbar y otras gomas de que abunda el país, etc. etc., por la suma de quinientos pesos mensuales, durante el tiempo que inviertan en sus trabajos, siempre que se les suministren los instrumentos indispensables de Topografía, Meteorología y cinco rifles nacionales. Puesto en discusión el dictamen indicado se aprobó en todas sus partes. En consecuencia, queda acordado se diga al Poder Ejecutivo que, por ahora, conviene desestimar la propuesta de que se ha hecho relación. Con tal objeto se devolverá a la Secretaría de su procedencia el escrito de que se ha hecho mérito, acompañándole copia autorizada del dictamen a que el mismo se refiere y transcripción del presente acuerdo".

En otras palabras, el proyecto abortó debido a las difíciles circunstancias económicas por las que atravesaba el país, lo cual impedía hacer frente a tal erogación de los fondos públicos. 
Un hecho a resaltar del proyecto de libro es su visión claramente utilitaria, como se percibe del énfasis en ciertas riquezas naturales. Al respecto, la vainilla (Vanilla planifolia y otras especies congéneres) es una orquídea de cuyo fruto se extrae un saborizante muy codiciado para repostería, helados, etc. Por su parte, en cuanto a la quina, existe una especie nativa, llamada Ladenbergia brenesii en honor a su primer recolector, el botánico Alberto Manuel Brenes, pero lo hizo en años posteriores a la gira de Thiel; por tanto, es de suponer que más bien se trataba de sembrar en Costa Rica la quina suramericana (Cinchona officinalis), pues su corteza contiene un alcaloide denominado quinina, muy comercializado entonces para el combate de la malaria. En cuanto al ámbar, corresponde a una resina secretada por algunos árboles, utilizada sobre todo en joyería.

Pero, ¿qué relación hay entre el citado proyecto y Thiel, que es el sujeto de este artículo? Imposible decirlo con tan solo la información oficial recién transcrita, pero se cuenta con un testimonio de primera mano, proveniente de Isabel Alfaro de Jiménez, hija de Anastasio Alfaro. Ella manifiesta que los tres jóvenes "buscaron la colaboración del ilustre prelado Monseñor Thiel, que se las ofreció plenamente. Este acto de fe del gran Obispo colmó su optimismo. Igual actitud encontraron en el Prof. Porras" (Garrón de Doryan, 1974).

Es decir, en algún momento ellos percibieron que, debido a su erudición y conocimiento del territorio nacional, el apoyo de Thiel le daría más credibilidad a su propuesta, y entonces lograron que los apadrinara; asimismo, era de esperar que Thiel mostrara interés en la sistematización de la información referida a la geografía de nuestro país, en la forma de un libro o tratado. De hecho, el párrafo recién transcrito sugiere que Porras no tuvo un papel protagónico en la gestación del proyecto, sino que se limitó a apoyar a tan capaces jóvenes.

En cuanto a Porras, su discípulo Alfaro (1930) se expresaba muy bien de él, y hasta le atribuía el mérito de haber propuesto la creación de un Museo Nacional, lo cual no es cierto, pues quien hizo esto fue el francés Louis Chéron (Hilje, 2014). En realidad, Porras no tenía formación científica, sino que era autodidacta, y ni siquiera era docente en el Instituto Nacional, sino que laboraba como preparador o ayudante de instrumental científico y de unas colecciones de historia natural; por cierto, era primo hermano del por entonces extinto expresidente Juan Rafael Mora Porras. Es importante acotar que Polakowsky, colega suyo en el Instituto Nacional, tenía un muy mal concepto de Porras como científico (Hilje, 2013). 
Ello explica que, cuando ya vivía en Berlín, y al enterarse por La Gaceta de que el proyecto del libro había abortado, le manifestó a Thiel su satisfacción por lo ocurrido (AHABAT, I. 276, t. 1, f. 337-338), y le expresaba que Porras era un gran ignorante, que no tenía idea de nada científico. Asimismo, en su criterio, ninguna persona residente en el país tenía la capacidad para escribir una Flora y fauna de Costa Rica, además de que habría que tener acceso a los especímenes que estaban en museos de Europa. Le comentó que cuando él conoció a Porras, éste no tenía idea de la sistemática ni de la morfología de las plantas, etc. y seguramente ni siquiera sabía usar un libro de botánica. Eso sí, conocía bien los pueblos indígenas y la forma en que están relacionados entre sí, además de que podría recolectar productos del país y consignar bien su procedencia, altitud y frecuencia de distribución, así como sus nombres indígenas conocidos y en español. Además, podría aportar algunos datos respecto a la geografía física de Costa Rica, aunque no la conocía tanto como Thiel o el ya citado Figueroa.

En su carta, Polakowsky no desaprovechó la oportunidad para solicitarle a Thiel que intercediera en su favor, en caso de que hubiera posibilidad de que el gobierno de Costa Rica tuviera interés en un proyecto referido a la Flora y fauna de Costa Rica, el cual él efectuaría por la módica suma de 1000 pesos; por cierto, casi 30 años antes el naturalista y médico alemán Karl Hoffmann se había propuesto escribir un libro con ese mismo nombre, junto con varios colaboradores, pero su prematura muerte lo impidió (Hilje, 2006). Para ello, si a Thiel le parecía, él podía escribirle directamente a José María Castro Madriz, por entonces ministro de Beneficencia, Culto y Relaciones Exteriores, o incluso al presidente Bernardo Soto. Ignoramos si Thiel le ayudó, aunque quizás después se enteró de que a Polakowsky se le había instituido una causa ad perpetuam por tener relaciones íntimas con una prostituta en un laboratorio del Instituto Nacional, lo cual implicó la rescisión de su contrato y su despido, lo cual está ampliamente documentado en Hilje (2013).

Ahora bien, para retornar al proyecto de libro de Porras y colaboradores, es importante destacar que, a pesar de ver frustrados sus anhelos ante tan inesperado tropiezo, los tres jóvenes continuarían desarrollando sus potencialidades y sus actividades intelectuales. De hecho, Gagini se convirtió en un notable lingüista y escritor, mientras que el zoólogo y arqueólogo Alfaro fue el primer director del Museo Nacional. En su madurez, ambos mantuvieron una buena relación con Thiel, desde sus respectivos campos profesionales. 
En el caso de Twight -tío del biólogo Clodomiro Picado Twight, a quien se aludirá pronto- fue un destacado profesor de secundaria y ocupó un importante puesto en la cartera de Obras Públicas. No obstante, en un acto que estremeció a nuestra sociedad, se suicidó exactamente tres años después, el 15 de setiembre de 1886, luego de asistir a la inauguración de la Exposición Nacional (Hilje, 2013); un año antes que él, había obrado igual su padre Enrique Twight Collins, de nacionalidad inglesa, y quien laboró como traductor oficial del Estado por varios años. Su muerte debe haberle dolido mucho a Thiel, a quien ese año se le había autorizado el retorno a Costa Rica, tras su expulsión.

Para concluir esta sección, irónicamente, fue gracias a la Exposición Nacional que Bernardo Soto -yerno de Fernández Oreamuno, y responsable de que Thiel retornara al país-, ya como presidente de la República, captó la importancia de establecer un museo. Por tanto, tomó la decisión de enviar a Anastasio Alfaro al Instituto Smithsoniano para que se preparara en la administración de este tipo de instituciones. Poco después de retornar, el 4 de mayo de 1887 se fundaba de manera oficial el Museo Nacional y Alfaro asumía su dirección.

\section{La flora en las crónicas de Thiel}

\section{Aspectos generales}

Puesto que las crónicas de las visitas pastorales de Thiel se centran casi exclusivamente en aspectos de carácter religioso, no cabría esperar amplios comentarios o menciones de la flora y la fauna de los territorios recorridos; ello explica que esta temática no ocupe siquiera el $5 \%$ de tan voluminosos escritos, según un cálculo aproximado nuestro. Sin embargo, expuesto a condiciones y vivencias idénticas, es muy posible que ningún otro religioso hubiera incluido las observaciones y acotaciones que Thiel hizo, las cuales revelan un vivo interés suyo por documentar la relación del ser humano con la naturaleza.

Antes de profundizar en estos aspectos, es pertinente hacer una digresión para indicar que cuando Thiel llegó al país, no había ningún botánico que pudiera ayudarle u orientarlo. Previamente habían residido aquí el danés Oersted, los alemanes Hoffmann y Polakowsky, y el alsaciano Endrés. El único que permanecía era el también coterráneo Carmiol, quien no era científico, sino recolector de plantas y animales. En años posteriores, hacia el final del siglo XIX llegarían los botánicos Pittier, Tonduz y Wercklé, quienes serían los formadores de los jóvenes Alberto Manuel Brenes Mora y Otón Jiménez Luthmer, este último nieto de alemanes. 
Ahora bien, para referirse a la flora conviene destacar que, lógicamente, la mayor parte de las menciones aluden a especies de utilidad para los pobladores de las comunidades visitadas, ya fuera como cultivos agrícolas, como árboles productores de maderas de alta calidad, aptas para construcción de edificios o para ebanistería, o como plantas silvestres aprovechables por su potencial alimenticio, medicinal, textil, tintóreo, etc.

Al respecto, un elocuente y hasta poético testimonio aparece en un relato de 1896, referido a Upala, en el que Thiel decía que

\begin{abstract}
"cualquiera que viaje al través de esta región no puede hablar sino con admiración de la hermosura y exuberancia de aquel suelo, virgen como al siguiente día de la creación, que la dulzura del aire que se respira y el recurso extraordinario para toda clase de cultivos y explotaciones industriales transforman en un pequeño edén. Algunas leguas cuadradas de aquel suelo, cultivado de café, cacao, caña de azúcar, arroz, maíz, algodón y tabaco, aumentarían la riqueza nacional, y harían la felicidad de muchas familias, que en nuestro interior no tienen una choza en qué abrigarse ni un palmo de tierra que cultivar". Y continuaba resaltando que "en aquellas inmensas soledades jamás se ha oído el ruido del hacha, ni el roce del machete. Hermosas y variadas maderas de ebanistería y de construcción; gomas y resinas, aceites y bálsamos, diversas materias tintóreas, aún desconocidas, toda clase de plantas textiles, he aquí la gran riqueza todavía sin explotar de aquella región, regada por el Río Frío, cuyas aguas pueden dar acceso a pequeños vapores y grandes bongos comerciales".
\end{abstract}

Otro ejemplo proviene de inicios de 1896 cuando, al penetrar en el río Tempisque desde el golfo de Nicoya y rumbo al puerto fluvial de El Humo, Thiel narraba que

\footnotetext{
"a uno y otro lado se ven grandes llanuras pobladas de abundantes pastos e interrumpidas por espesos bosques. Los primeros son excelentes para el engorde del ganado y las selvas abundan en maderas de construcción, tales como el cedro amargo, el madera negra [madero negro], el guachipelín, el caoba, etc.; en plantas textiles, como la pita, el soncollo, el pochote, la balsa, etc.; en plantas tintóreas y medicinales, como el nancite, el jiquelite, el saca-tinta, la amapola, la higuerilla, la juanilama, la verbena, la cola de alacrán, el guarumo, etc.".
}

Conviene indicar que los nombres científicos de las especies citadas son: cedro amargo (Cedrela odorata), madero negro (Gliricidia sepium), guachipelín (Diphysa americana), caoba (Swietenia macrophylla), pita (Aechmea magdalenae), soncollo (Annona purpurea), pochote (Pochota fendleri), balsa (Ochroma pyramidale), nancite o nance (Byrsonima crassifolia), jiquelite o añil (Indigofera suffruticosa), saca-tinta, amapola (Hibiscus arboreus), higuerilla 
(Ricinus communis), juanilama (Lippia alba), verbena (Salvia sp.), cola de alacrán (quizá Heliotropium indicum) y guarumo (Cecropia peltata) (León y Poveda, 2000). En cuanto al saca-tinta, nombre inexistente, según el botánico Quírico Jiménez podría tratarse del guaitil (Genipa americana), que secreta una coloración azulada cuando trozos de sus tallos leñosos se sumergen en agua.

Asimismo, ya instalado en Santa Cruz, Thiel comentaría que

\begin{abstract}
"el clima es caliente y bochornoso a mediodía, pero fresco y agradable en la tarde y en la mañana. Grandes pastos rodean la población, sombreados por frondosos y elevados árboles de mango, de tamarindo, de espabeles [espaveles] y de marañones, cuyas frutas son tan medicinales como exquisitas al paladar, [para después expresar que] la mayor parte de sus habitantes se dedica a la cría del ganado, que gordo y hermoso vaga por esas Ilanuras cubiertas de grama, gamalote, arrocillo, pará, pie de paloma y demás pastos naturales de las ciénagas. Otros dedícanse al cultivo de la tierra".
\end{abstract}

Los respectivos nombres científicos de las especies de árboles mencionadas son Mangifera indica, Tamarindus indica, Anacardium excelsum y Anacardium occidentale, en tanto que los de los pastos son Cynodon dactylon (grama), Paspalum fasciculatum (gamalote), Anthephora hermaphrodita (arrocillo), Urochloa mutica (pará) y Axonopus fissifolius (pie de paloma) (León y Poveda, 2000).

\title{
Plantas cultivadas
}

En las crónicas de Thiel hay decenas o centenares de alusiones a plantas cultivadas, ya sea por su valor alimenticio (maíz, frijol, plátano, arroz, yuca, camote, ñame, algunas hortalizas, etc.), como frutales (banano, zapote, jobo, mango, marañón, guanábana, naranja, limón, piña, sandía, tamarindo, níspero, nance, manzana rosa, etc.), bebidas (cacao y café), textiles (algodón), endulzantes (caña de azúcar), condimentos (pimienta), pigmentos (achiote), medicinas (zarzaparrilla) y drogas (tabaco). Aunque, debido a su valor en la vida cotidiana de las comunidades rurales, es tentador referirse en detalle a estas especies -y ello podría resultar un amplio artículo o incluso a un pequeño libro-, varios de estos cultivos son exóticos, pero este artículo se enfoca en plantas silvestres nativas de la región mesoamericana. No obstante, en algunos casos muy particulares y que lo ameritan se harán excepciones. 
Por ejemplo, al referirse a la feracidad de la zona de Upala para la siembra de cacao (Theobroma cacao), Thiel subraya que "cierto es que, durante cuatro o cinco años, la cosecha se hace esperar, pero una vez que empieza, los gastos del madreado se reparan y los centavos aumentan el capital". Esto significa que hay una demora de varios años para que se inicie la fructificación, y que a partir de entonces se recuperan los costos de la siembra y mantenimiento del madreado, madrecacao o madero negro (G. sepium). Bien sabido es que, desde tiempos inmemoriales, los aborígenes sembraban este árbol como acompañante del cacao, como lo documentó a mediados del siglo XVI el cronista italiano Jerónimo Benzoni al recorrer el istmo centroamericano (Benzoni, 1565); hasta hoy, se le utiliza como árbol nodriza en sistemas agroforestales con cacao pues, por ser una leguminosa, fija el nitrógeno atmosférico y enriquece los suelos, a la vez que aporta sombra. Como una curiosidad, Thiel califica al cacao como "alimento de los dioses", quizás porque sabía que, en griego, la etimología de su nombre genérico (Theo $=$ dios, broma $=$ alimento) corresponde a este significado.

Otra de las excepciones es la de un cultivo denominado "patriota", al cual se aludió en un relato previo, inspirado en las cercanías del río Bitey, en Talamanca. A esa mención se suman cuatro más, iniciando con una en la que, poco después del río Sarí, había "un rancho grande, desierto, rodeado de extensos plantíos de patriota", para posteriormente cruzar "extensos cañaverales, sucios lodazales y largos, muy largos patriotales", y luego toparse con un hermoso y plano predio con "un patriotal muy crecido", más otro "muy abundante en pesca, [en el que] hay solo un trecho de tierra cultivado con patriotas".

En realidad, se trataba del banano, a juzgar por la siguiente explicación de Pittier (1908):

"Otra planta, importada probablemente de alguna de las Antillas, ha adquirido en los últimos veinte años una importancia enorme, desde el punto de vista industrial para la tierra caliente del Atlántico, y ha dado un carácter especial a toda la zona costanera. Me refiero al banano, o a la variedad del Musa sapientum conocida en Costa Rica con el nombre de patriota, aunque tiene muy poco de nacional, siendo de origen probablemente asiático, cultivado en gran parte por compañías y colonos inmigrados y consumida en Norte América y en Europa. Sin embargo, gracias a la nueva industria de que es objeto, se ha puesto en cultivo una vasta extensión de tierras fértiles que antaño se consideraban como sin valor a consecuencia de su mortífero clima, y dado también un poderoso impulso al desarrollo del puerto de Limón y al del país en general". 
En efecto, según León (1987), originalmente al banano se le asignaba el nombre científico de $M$. sapientum, en tanto que el de $M$. paradisiaca se reservaba para el plátano. Sin embargo, la genética y la taxonomía de la familia Musaceae son complejas, y hoy se considera que tanto el banano como el plátano son híbridos, es decir, cruces de dos especies emparentadas, a saber, $M$. acuminata y $M$. balbisiana.

Es muy interesante, eso sí, que a pesar de que el plátano es nativo del Viejo Mundo, se convirtió en muy apetecible para la fabricación de chicha, omnipresente bebida alcohólica sobre la cual hay incontables menciones en los relatos de Thiel. Fue así como, con el paso del tiempo, se sumó a tres cultivos originarios de América: el maíz (Zea mays), la yuca (Manihot esculenta) y el pejibaye (Bactris gasipaes). En palabras de él, quien se lamentaba del "modo asqueroso como la preparan" los indígenas, "la chicha de maíz y de pejibaye no la gustan sino en tiempo de la cosecha, mientras que la de yuca y plátano forma su bebida acostumbrada en todos los días del año". Para su preparación, "déjanla fermentar durante cuatro o cinco días, teniendo cuidado de moverla con un palo. Cuando está en su punto, convidan a los indios de todos los palenques, que vienen a beber, cantar y bailar durante todo el día, entregándose a las borracheras, y hasta a las riñas y los pleitos".

\section{Plantas silvestres útiles}

Ahora bien, para referirnos a plantas silvestres de utilidad en la vida cotidiana, sobresalen las de valor alimenticio, así como aquellas de las que se pueden elaborar utensilios (guacales, hamacas, cobijas, fajas, mallas o redes, arcos, flechas y lanzas, antorchas o teas, e instrumentos musicales), vestimenta (taparrabos o pampanillas), techumbres de ranchos, impermeabilizantes, colorantes, etc.

En realidad, las especies alimenticias no cultivadas citadas por Thiel son pocas. En contraste con las cultivadas por los indígenas, como el maíz, el frijol, el plátano y algunos tubérculos (yuca, camote y ñame), las plantas recolectadas directamente de la montaña corresponden al tacaco y a tres palmáceas. 
En el caso del tacaco, Thiel acota que mientras estaban en Talamanca,

"al principio nos faltaron los víveres, pero al otro día los indios trajeron bastante: como tepezcuintle, bobos del río Chirripó, plátanos, tacacos, maíz (negro y de clase inferior), yuca buena, naranjas dulces, limones y gallinas. Ellos tienen además cerca de sus casas, puercos y un poco de ganado".

El tacaco, de frutos deliciosamente amargos y pariente del chayote y al ayote (familia Cucurbitaceae), originalmente fue bautizado como Polakowskia tacaco por Pittier, pero hoy se le denomina Sechium tacaco. En cuanto al maíz morado, posiblemente se trataba de una variedad criolla, quizás la misma del que en Guanacaste llaman pujagua, según el fitogenetista Mario Saborío. A la fauna aquí mencionada se hará alusión en la sección respectiva.

De las palmáceas (familia Arecaceae), el pejibaye (B. gasipaes) produce copiosos racimos de frutos (Figura 6A) que, aunque fibrosos y secos, son muy nutritivos, en tanto que el palmito y la pacaya aportan suaves y deliciosos cogollos. Por ejemplo, en un pasaje referido a Upala, Thiel señala que todos los indios debían "huir al monte al acercarse los huleros, dejando sus casas y sus provisiones, y viviendo de raíces, de palmitos y pacayas", mientras que en otro sobre Tucurrique, narra que "tuvieron que satisfacer el hambre con palmitos $y$ pacayas que encontraron en el camino, y la sed con agua que encontraron en los tubos de la caña hueca que abunda en toda la montaña". Es oportuno aclarar que el palmito comestible proviene de la palmilera (Iriartea deltoidea), aunque también lo producen la palma conga (Euterpe precatoria) y el maquenque (Socratea exorrhiza). Asimismo, según el botánico Jiménez, la pacaya podría corresponder a Chamaedorea tepejilote y C. costaricana, mientras que se ignora el nombre científico de la citada caña hueca.

En relación con especies que aportan frutos comestibles, es muy poco lo que aparece en los relatos de Thiel, y se restringen a la provincia de Guanacaste. Además del párrafo ya transcrito sobre Santa Cruz, él acotaría que

"hoy día Nicoya, de clima agradable y sano, presenta el aspecto de una bonita población, siendo de lamentar que sus solares, grandes y espaciosos, no estén cercados y cultivados, al menos con árboles frutales que además de su utilidad, sirvieran de adorno y frescura a la población. Conocidos son por su buen gusto, los mangos, los zapotes y sonzapotes, las naranjas, las guanabas [guanábanas], las manzanas rosas, los zapotillos y marañones, los mameyes y nísperos, y otras mil frutas más, que por su tamaño, color y sabor, excitan a saborearlas". 
Figura 6. Dos frutos aprovechables: pejibaye (A) y jícaro (B).

A.

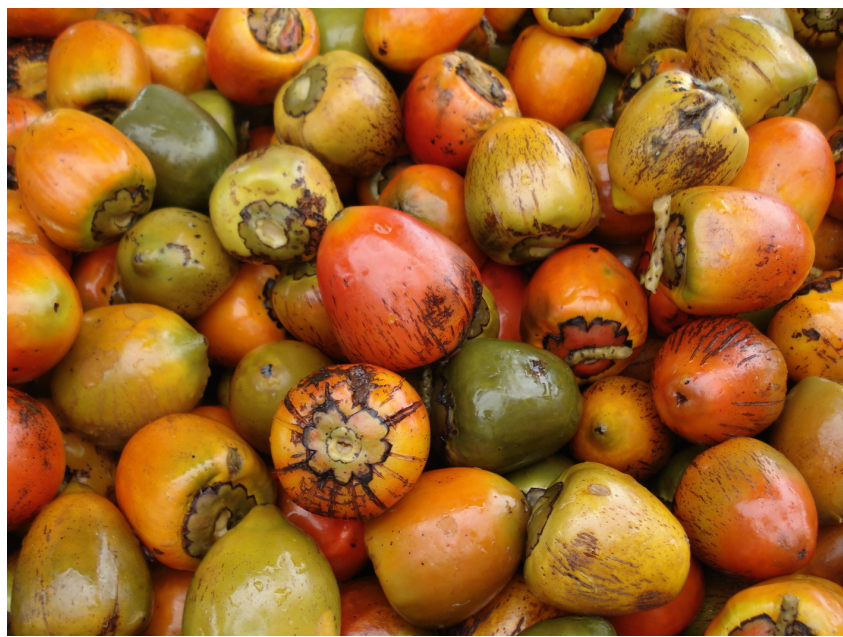

B.

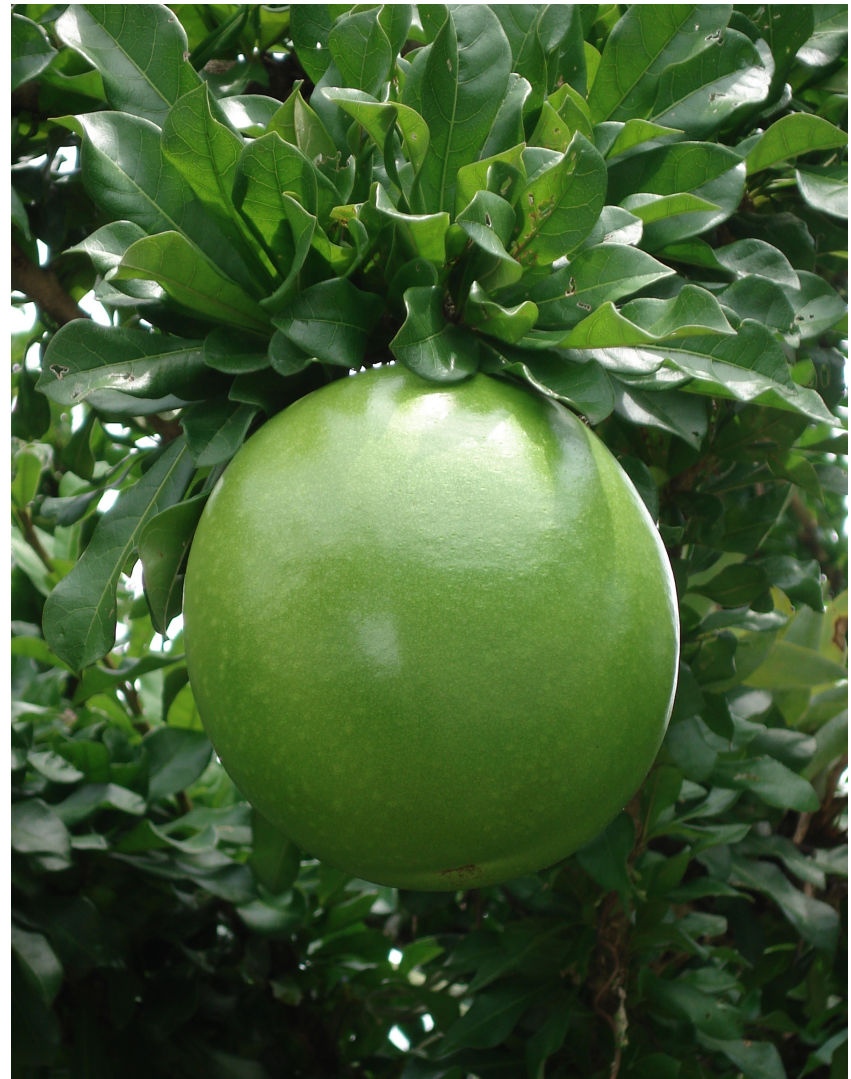


Los nombres científicos de estas especies son: M. indica (mango), zapote (Pouteria sapota), sonzapote (Licania platypus), naranja (Citrus sinensis), guanábana (Annona muricata), manzana rosa (Syzygium jambos), zapotillo (quizá Pouteria sp.), marañón (A. occidentale), mamey (Mammea americana) y níspero (Eriobotrya japonica) (León y Poveda, 2000).

Para continuar con este recuento de plantas silvestres útiles, Thiel menciona varias especies con las que los indígenas confeccionaban utensilios. De ellos, el más común era el guacal o jícara, recipiente elaborado a partir de los frutos del árbol de jícaro (Crescentia cujete) (Figura 6B). En efecto, Thiel anota que

"su cristalería consiste únicamente de unos negros y ordinarios guacales que llaman pupa, fruta grande de un árbol del mismo nombre, que rajada por la mitad y sancochada en el agua caliente, botando antes la semilla, les sirve para tomar sus bebidas. Cuando carecen de esos guacales, se valen de hojas grandes o de las palmas de las manos".

La forma globosa de los frutos, así como el hecho de que, al secarse, su cáscara sea dura y leñosa, convierte a los guacales en utensilios irremplazables para beber o comer.

No obstante, es de suponer que los guacales no siempre provenían del árbol de jícaro, sino de los duros frutos de la planta de calabaza (Lagenaria siceraria), con forma de botella, y cuyas bases se cortaban para obtener este tipo de utensilio (León y Poveda, 2000). Los guacales no se usaban solo para beber, sino que también para comer, como se nota a continuación:

"La comida de los indios es, por la mañana el cacao tibio, que se sirve en grandes guacales y a cada uno le asiste el derecho cuando le corresponde por turno, de ser el primero en poner la palma de la mano sobre la superficie de la bebida y untarse con la manteca que a ella le queda pegada. Al mismo tiempo se toman plátanos verdes y maduros asados. Estiman mucho el lustre que les da la manteca de cacao. A las 6 van al trabajo llevando en hojas de plátano la comida, que consiste en plátanos verdes asados, masa de yuca cocida y mascada. Esto lo comen en guacales mezclándolo con agua".

En cuanto a otras herramientas elaboradas a partir de plantas, Thiel señala que su actividad diaria

"se reduce entre ellos a la fabricación de arcos y flechas, de redes y hamacas; a la pesca, al cultivo de la yuca, del plátano, y del tabaco en muy pequeña cantidad, aunque más les gusta fumar nuestros cigarros y cigarrillos que nos pedían a cada momento. Sus alimentos son los plátanos asados sobre las brasas, o deshechos en agua, y la yuca, que podríamos llamar alimentos diarios". 
Asimismo, en cuanto a las hamacas para descansar, él anota que los indígenas

"comen y se sientan en el duro suelo, a excepción del hombre, que duerme en la hamaca con los chicos, si los hay, y la india en la tierra, sin más almohada que un pedazo de palo y sin más cobija que un pedazo de mastate. Las hamacas las hacen muy buenas, de la corteza del mismo mastate y del tamaño de una persona [...] Tanto sus hamacas como las redes que emplean para acarrear los plátanos, el cacao, etc., son muy finas y bien trabajadas y sin ninguna clase de pintura".

Ahora bien, cuando muere algún indígena, "envuelven el cadáver -antes de enterrarlo- en un poco de mastate y lo colocan en la sepultura". Es decir, la corteza o parte más externa del tronco de este árbol (Brosimum utile), que es pariente de los higuerones (familia Moraceae), se aporrea hasta adquirir una consistencia flexible, como una especie de lienzo.

Thiel amplía sus observaciones sobre la utilidad de este árbol para la vestimenta, al manifestar que los indígenas de Upala

"andan desnudos, cubriendo solamente las partes vergonzosas con una tela hecha de la corteza del mastate, prefiriendo ésta a los vestidos que se les dan en el interior. Machácanla con una piedra hasta dejarla bien tendida, lávanla después y les queda como una especie de manta, de que los hombres aprovechan una tira para pasarla por entre las piernas y atarla alrededor de la cintura, formando así lo que vulgarmente se llama taparrabo. Las mujeres se cubren con la misma corteza, de la cintura hasta media pantorrilla" (Figura 7).

Figura 7. Guatusos con taparrabo.

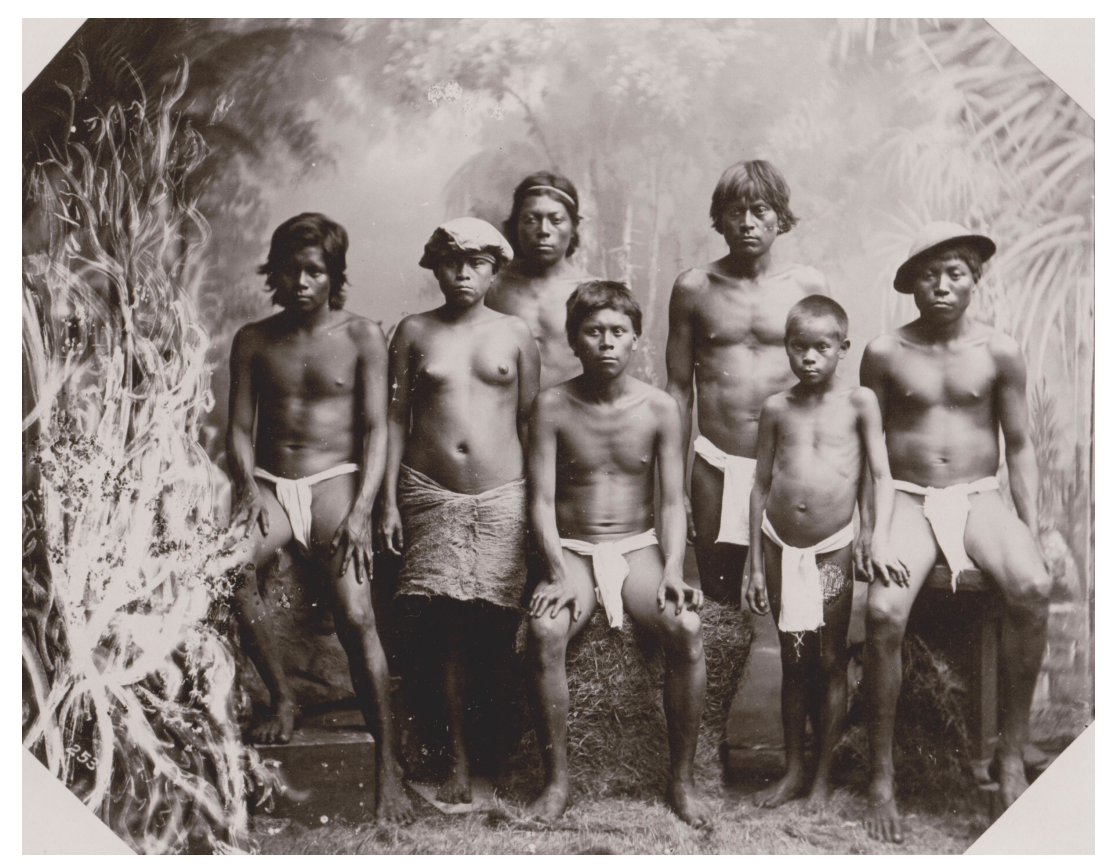

Foto: Walter Lehmann 
Además, en otro pasaje Thiel indica que los indios "siempre llevan su carga de bastimentos en grandes redes, suspendidas en la cabeza por una faja de mastate o cáscara de la mata de plátano y andando con un bordón en la mano".

Asimismo, varias veces Thiel alude a redes o mallas, así como a canastas. Por ejemplo, en una oportunidad consignó que, al llegar a un rancherío o palenque en Upala, "enseguida todos se pusieron a examinar los utensilios de los indios y encontraron redes grandes, canastas llenas de guacales; [...], flechas, arcos, machetes de madera y mil otros utensilios e instrumentos de los indios, y algunas hamacas bien trabajadas". También acotó que, infatigables, "las mujeres deben traer leña, hacer las canastas, redes y hamacas", para resaltar que "ellas cuidan de la cocina, traen la leña y los plátanos para sus alimentos; hacen la chicha, y cuando viajan llevan sobre sus espaldas las grandes redes con carga, y más arriba sus niñitos; mientras que el indio camina adelante sin nada que le moleste". En otra parte, indica que "una india se ocupaba en hacer cordeles para una red, con mucha delicadeza y prontitud. Las redes son de dos clases: grandes y ordinarias para llevar sus cargas de plátanos sobre los hombros, y pequeñas y finas para pescar".

Sin embargo, llama la atención que él no especifica de cuál planta tomaban los indígenas las fibras para fabricarlas. Es de suponer que, al igual que en Talamanca (León y Poveda, 2000), las redes fueran confeccionadas con fibras de pita ( $A$. magdalenae), de la misma familia de la piñuela, que otrora era muy común como cerca o vallado para delimitar propiedades. No obstante, en Talamanca también hay otras plantas que aportan materiales parecidos. Una de ellas, la cual parece una palma pero no lo es, corresponde a la chidra, chirrabaca o estococa (Carludovica palmata), fuente de fibras suaves para confeccionar diversos productos. Asimismo, hay dos especies de bejucos, la majagua (Hibiscus pernambucensis) y el burío (Heliocarpus appendiculatus), aptos para elaborar redes, según el botánico y etnógrafo Rafael Ángel Ocampo.

Ahora bien, en algunas comunidades indígenas del país, para la techumbre de los ranchos se emplean las grandes hojas de una palmera llamada cola de gallo o suita (Calyptrogyne ghiesbreghtiana) (Figura 8). Así lo atestiguó Thiel en Upala, al expresar que "llegaron como a las 6 a los tres palenques grandes y encontraron a todos reunidos. [...] Todos estaban admirados de la laboriosidad de los indios, que se nota especialmente en el modo de hacer el techo de los ranchos, hechos de hojas de cola de gallo". Y, en cuanto a su estructura general, manifestaba que 
"estos ranchos, altos en el centro, con techo de hojas de palma que viene en declive hacia ambos lados, sostenido por gruesos horcones, están abiertos a todo viento por los extremos y los lados".

Figura 8. Rancho indígena techado con suita, en Talamanca.

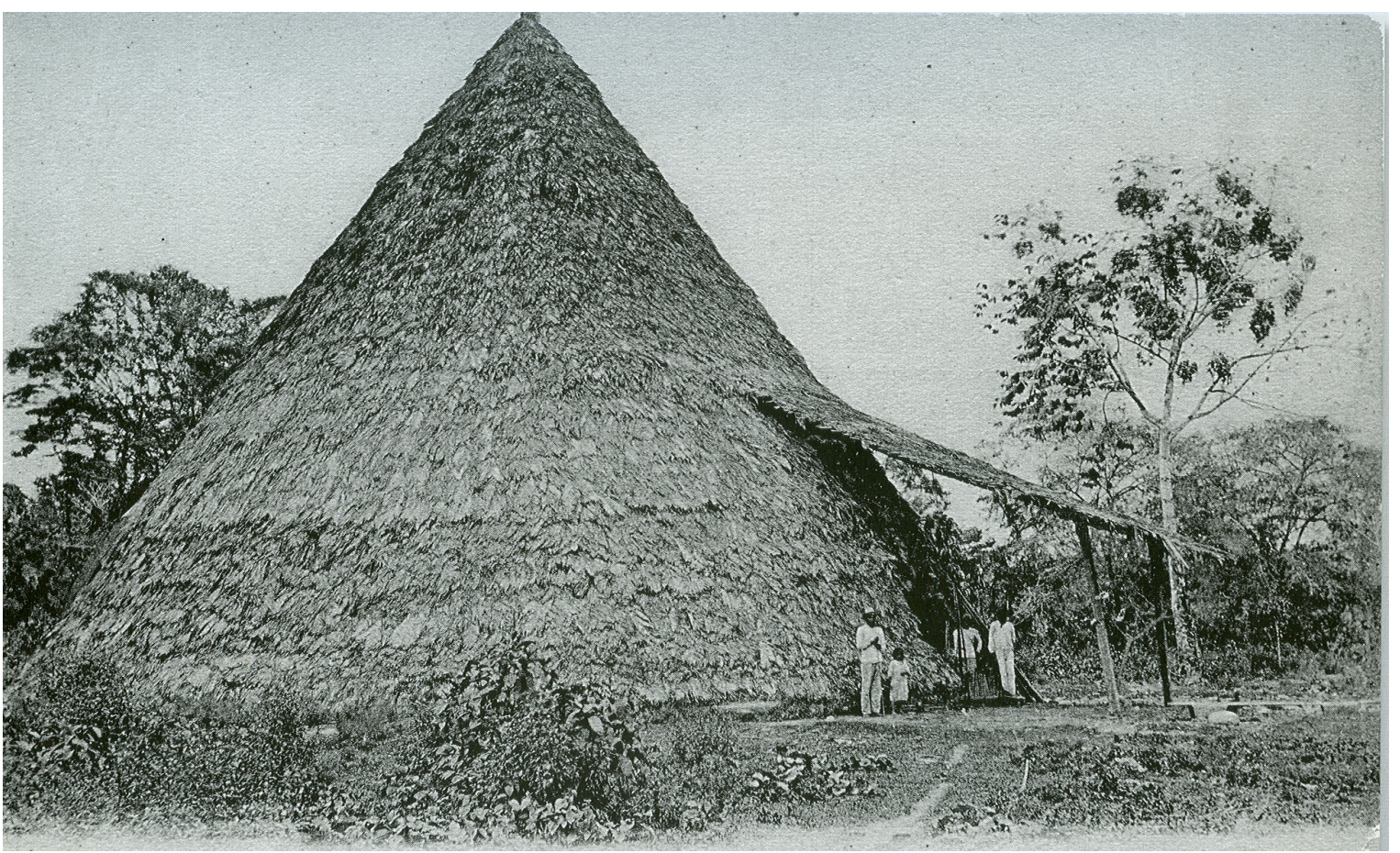

En otra oportunidad, en Sipurio, Talamanca, Thiel se regocijaba de que ya había varios centenares de indígenas convertidos al cristianismo, quienes incluso habían levantado "una iglesia con los ornamentos muy precisos, una casa cural contigua y una cocina y casa de sirvientes, todo en madera de palmilera y techo de paja". Cabe interpretar que, una vez extraído el palmito, los tallos o troncos de la palmilera o chonta eran rajados y extendidos, para colocar de forma horizontal como material de cerramiento, como se hace aún hoy en las viviendas talamanqueñas, según el antropólogo Fernando González. En cuanto a la citada paja, es posible que se tratara de una gramínea (familia Poaceae), aunque no necesariamente, sino algún otro material vegetal, diferente de la suita. 
Por cierto, hay una acotación muy interesante en relación con el uso de los tallos de palmas, a saber:

\begin{abstract}
"Desde que nuestro Prelado empezó a civilizarlos, han comenzado a usar nuestros machetes de acero, desapareciendo los de madera con que gastaban mucho tiempo y trabajo para hacer un desmonte y miles de machetazos para cortar un árbol grueso. El árbol del que hacían los machetes, es el pejibaye".
\end{abstract}

Esta palma (B. gasipaes) es pariente de la recién citada palmilera, y sus troncos también eran la materia prima para la confección de arcos y flechas, como se capta a continuación.

En efecto, utilizaban estas armas para disparar y "flechar el pez desde la orilla del río, arrojándose al agua a sacarlo junto con la flecha. Son estas muy largas y livianas, hechas del tallo de la flor de la caña silvestre, con la punta del corazón de pejibaye"; según el botánico Jiménez, esta caña podría ser la caña blanca o caña brava (Gynerium sagittatum), de la familia Poaceae, cuyos tallos pueden medir hasta $4 \mathrm{~m}$, lo cual los hace aptos para ser usados en cielorrasos. En cuanto a los arcos,

\footnotetext{
"los usan de pejibaye con una cuerda bien tirante, siendo muy diestros en esta clase de puntería. Las que usan para cazar cuadrúpedos son más pequeñas y tan fuertes que puede traspasar un animal de una parte a otra, sin que se rompan. Nos cuentan que una vez encontraron un hulero clavado y muerto con una de estas flechas, en el árbol del que sacaba la goma. Algún indio, sin duda, lo sorprendió cortando lo que ellos tanto utilizan, y se vengó con su flecha mortífera".
}

Ahora bien, siempre en relación con la utilización de maderas, Thiel anota que los indígenas

\footnotetext{
"usan también el fuego para la limpia de los desmontes, y aunque ya conocen el uso de los fósforos europeos, a menudo recurren a sus fósforos indígenas, que consisten en la frotación de dos pedazos de leña seca. Con mucho esmero y cuidado tratan de conservar día y noche sus fogones encendidos para evitarse el trabajo de volverlos a encender".
}

De hecho, en otro pasaje de su relato anota que cerca de cada fogón mantienen palos para obtener fuego mediante la fricción de un palo con otro, pero no aclara si se trata de una especie botánica en particular. Al respecto, es interesante que entre los objetos remitidos por Thiel para la Exposición Histórico-Americana en Madrid, había "varios utensilios para encender fuego", como se indicó en páginas previas. 
A propósito del fuego y la iluminación, es pertinente indicar que en los palenques se dependía de los fogones utilizados para cocinar sus viandas. En palabras de Thiel, "el humo de la leña les defiende también de los piquetes de los insectos. Por esto es que al acercarse la noche lo primero que hacen es alistar su fuego, que tienen buen cuidado de atizar durante la noche, sin cuidarse de iluminar el palenque con ninguna otra clase de luz". Lo que no se menciona es el uso de antorchas, excepto por una referencia al ya citado árbol de hule, en la que se consigna que "los indios, como es natural, defendían el árbol, de cuya goma hacían su luz y de cuya corteza sus vestidos, sobreviniendo ataques entre indios y huleros". Es decir, extraían el látex y lo usaban como combustible; la alusión a la vestimenta posiblemente se refiere más bien a la utilidad del látex para impermeabilizar algunas prendas, como ya se indicó.

Por cierto, el látex del árbol de hule también permitía confeccionar la cabeza de los bolillos con los que se tocan las marimbas, de las cuales Thiel dice:

"La gente de Filadelfia, lo mismo como la de todo el litoral del Pacífico, es muy adicta a las diversiones, en las que la famosa marimba desempeña casi siempre su papel. Es la marimba un instrumento musical compuesto de un teclado de madera que gradualmente disminuye, colocado sobre unas jícaras de calabazo, en cuyo fondo se encuentra un pequeño agujero cerrado con cera y tela de araña, para dar sonoridad al golpe producido por un bolillo de caucho".

Nótese que los resonadores, ubicados debajo de cada tecla, correspondían a calabazas duras y vacías, provenientes de la ya citada L. siceraria, que es una enredadera silvestre, posiblemente nativa de África (León y Poveda, 2000).

Cabe señalar que en los relatos de Thiel aparecen citadas otras plantas, pero de manera apenas tangencial. Por ejemplo, anota que "en Moín se celebró la santa misa bajo un hermoso árbol de pan", que obviamente corresponde al fruta de pan (Artocarpus altilis), árbol exótico, de frutos muy gustados. Asimismo, apunta que "concluida la misa se preparó para el viaje el altar portátil que ha servido en toda la visita. Se preparó el viaje, antes de partir Su Señoría y compañeros tomaron un poco de leche en la célebre mesa que había tenido hojas de bijagua por mantel", en alusión a esta planta, también denominada bijao o platanilla (Calathea crotalifera o C. lutea), que crece densamente cerca de cuerpos de agua, como lo confirma el propio Thiel en un pasaje en que expresa que, en las cercanías del río Coén, "nos perdimos en un platanillar inmenso, de donde salimos con mucho trabajo". 
Igualmente, Thiel menciona que las hermosas ollas que fabrican los indígenas con el fin de fermentar la chicha y calentar el agua para el chocolate

\footnotetext{
"las hacen las mujeres, de un barro especial, puliéndolo con la mano. Las ponen a secar a los rayos del sol y después las queman al aire libre en un fogón de leña amontonada sobre ellas. Las pulen de nuevo con la semilla del ojo de buey, dejándolas muy lustrosas y de color barniz".
}

El nombre científico de esta planta, pariente del frijol, es Mucuna pruriens.

Por otra parte, anota que "los hombres se pintan la cara, brazos, piernas, pecho y vientre con una tinta colorada que extraen de la corteza de un árbol que llaman catazin, mascándola con los dientes y depositándola con mucho cuidado en un pedazo de caña brava. Usan también del achiote". El achiote (Bixa orellana) es un arbusto nativo de cuyas semillas se extrae un pigmento rojo, también utilizado como condimento, para conferirle una tonalidad rojiza a algunos alimentos. En cuanto al catazin, aunque en México hay un árbol conocido como catzim, kaatsim o katsim (Senegalia gaumeri), es poco probable que se tratara de esta especie, por lo que más bien podría corresponder a otra especie arbórea que secreta savia roja, perteneciente a los géneros Pterocarpus o Vismia, según el botánico Jiménez. Por su parte, la citada caña brava es Gynerium sagittatum, que crece de manera densa en las riberas de los ríos.

Ahora bien, aunque en un relato Thiel indica que "estos indios son tan desgraciados, que ni siquiera acuden en sus enfermedades al uso de ciertas yerbas medicinales que abundan en aquellos lugares", en realidad no menciona nombres de plantas con dichas propiedades. Amplía sus observaciones para acotar que "sus enfermedades principales son: la tisis, las úlceras, las calenturas y la anemia, debida esta última a la carencia de alimentos nutritivos" y que "puede decirse que no tienen ningún remedio, a excepción de los baños de agua fría, que mal aplicada más bien les perjudica, y de las hojas de ortiga con que se flagelan el cuerpo cuando están cansados o se sienten resfriados". Esta ortiga podría ser Urera baccifera, en opinión del botánico Jiménez.

Aparte de esta mención, hay apenas dos más sobre plantas medicinales. En una oportunidad, Thiel escribe que "muchos se ocupan en sacar zarza y hule", en alusión a la zarzaparrilla (Smilax regelii y S. vanilliodora, que algunos autores consideran que son la misma especie), planta cuyas raíces incluso se exportaban en aquella época, pues de ellas se extrae un producto de sabor agradable, 
utilizado para refrescos y con fines medicinales. En otro caso especifica que bendijeron "agua en bastante cantidad, bastante palma real, muchas semillas de cedrón (contra venenos), cruces, medallas, rosarios, etcétera". De estas plantas, la palma real quizás era Attalea rostrata, de acuerdo con el botánico Jiménez; al cedrón (Simaba cedron), del cual León y Poveda (2000) acotan que los indígenas lo sembraban debido a las propiedades medicinales de sus semillas se hará referencia posteriormente.

Para concluir esta sección, hay una interesante carta de Thiel a José María Castro Madriz, en su condición de ministro; este abogado había gobernado el país en tres oportunidades. Fechada en San José el 23 de octubre de 1882, en ella manifestaba que a los indígenas de Talamanca "lo que les hace mucha falta es la asistencia de un médico, que pasara siquiera una vez al año por esas regiones y acostumbrara a los indios a dejar sus modos ridículos de curar a los enfermos". Sin embargo, no era una queja en general, sino motivada por un hecho de naturaleza etnobotánico, es decir, de la utilización de plantas con propiedades medicinales por parte de ciertos grupos étnicos.

En efecto, a continuación explicaba el motivo específico de su molestia, al comentar que

\footnotetext{
"he descubierto por medio de averiguaciones que he tomado de las personas principales, como del señor John Lyon, del indio a quien titulan rey [Antonio Saldaña] y de otros, que existe entre las mujeres indias un abuso muy criminal, que a todo trance debe extirparse. Consiste en que las mujeres casadas, con el fin de no tener sucesión, se sirven de cierto polvo proveniente de la fruta o cáscara de un árbol que se encuentra en la pendiente occidental de la cordillera, en las cercanías de los pueblos de Térraba y Boruca. Debido a este fatal uso, no aumenta la población de los indios. Nacimientos y defunciones están en igual número. Las mujeres indias que no usan de este remedio tan fatal y pecaminoso, tienen muchos hijos y muy sanos. Sería bueno que la autoridad inmediata, que es la de la gobernación del Limón, reciba del Supremo Gobierno órdenes terminantes para dictar las medidas más a propósito que puedan contribuir a quitar aquella costumbre".
}

Empero, interesado en los aspectos científicos de su hallazgo, se propuso identificar dicha planta, que él consigna con el nombre "munra toctaci" -como se verá pronto-, así como estudiar con mayor detalle sus principios activos.

Por tanto, a fines de 1882 o inicios de 1883, Thiel envió a su amigo epistolar Polakowsky algunas muestras, según se colige de una carta de éste, fechada el 16 de enero de 1884, en la que le manifiesta lo siguiente: 
"Espero con gran interés el envío de la munra toctaci y una cantidad de fruta madura e inflorescencias, así como, si lo consiguieron, del polvo (por lo menos $10 \mathrm{~g}$ ) para que los analicen a fondo. Yo he examinado el polvo bajo el microscopio utilizando alcohol. Se disuelve una parte del mismo y, cuando se disipa el alcohol, se observan estructuras bellas, traslúcidas, con picos, brillantes y cristalinas. ¡Espero recibir un resultado científico muy interesante!" (AHABAT, I. 276, t. 1, f. 321-322).

\section{A continuación acotaba que}

"no tengo claro por qué los indios conducen a sus tribus de esa manera tan refinada a la extinción. Con algo de trabajo, con seguridad no falta el alimento en la fértil Talamanca. Las desembocaduras de los ríos donde crece este arbusto, ¿son secas y pedregosas o pantanosas y ricas en humus?".

Como se aprecia, Polakowsky analizó algunas muestras del polvo en el microscopio -algo no muy útil ni siquiera en términos botánicos-, pero el material era insuficiente para lo realmente importante, que eran los análisis fitoquímicos, que solo un verdadero especialista podía efectuar. Fue por eso que, como se lo comentó a Thiel en una nueva carta -por cierto muy seguida, pues data del 4 de febrero (AHABAT, I. 276, t. 1, f. 337-338)-, el 18 de junio de 1883 había visitado a su afamado maestro, el catedrático August Wilhelm von Hofmann, director del Laboratorio Químico de la Universidad de Berlín. Sin embargo, aunque a éste le interesó el asunto, estaba muy ocupado, por lo que le aconsejó que buscara al Dr. Óscar Liebreich (Figura 9), director del Instituto Farmacológico y del Laboratorio Químico Fisiológico de Berlín.

Liebreich (Figura 9) sí se entusiasmó mucho, pero necesitaba suficiente material para sus análisis. Es por ello que, en la carta de inicios de febrero, en la que se refería con cierto detalle a un helecho con propiedades antiofídicas -al que se aludirá en detalle después-, le manifestaba que

"el polvo de Talamanca (munra toctaci) producirá con seguridad un resultado muy interesante. Pero la cantidad que se me envió es tan exigua que no se puede examinar más detalladamente. Tuve el honor de informarle más al respecto a Su Eminencia en la carta pasada".

Aunque ahí no cita cantidades, esto explica que, el 3 de abril de 1884, Thiel le escribiera a Lyon para comunicarle que

"los profesores de Europa me piden 20 gramos del polvo de los indios, que ellos llaman munra y que sirve a las mujeres para sus usos criminales. Se trata de examinar científicamente este polvo. Lo mismo me piden una cantidad de frutas, maderas y flores del árbol de que se toma; una rama del árbol, pedazos de la raíz, etc. En el interés de la ciencia, espero de usted me proporcionará estas cosas, que mucho necesito para enviarlas a Washington y Berlín". 
Figura 9. El farmacéutico alemán Liebreich.

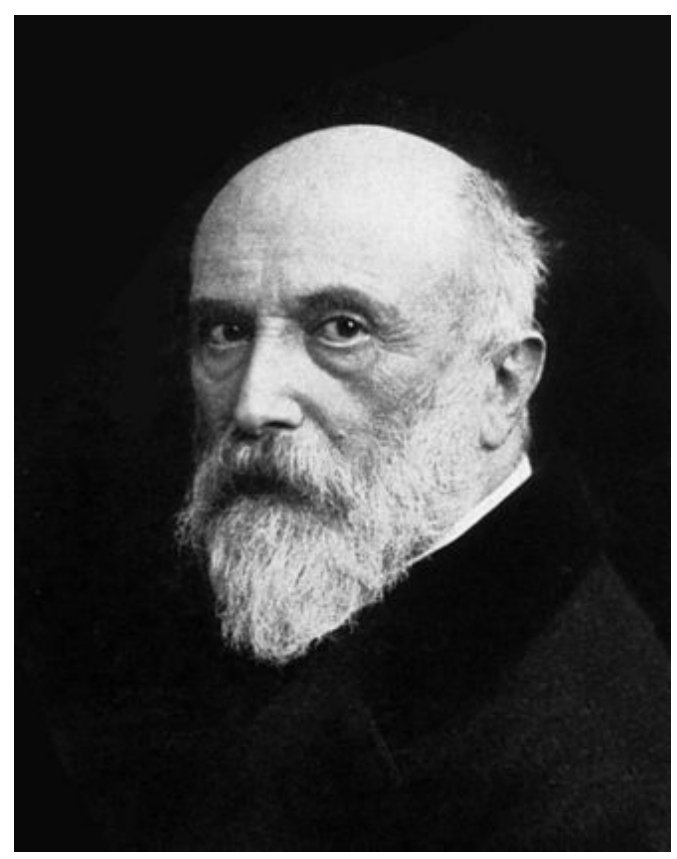

Fuente: Wikipedia.

Asimismo, insistente, en la postdata de otra carta, remitida cinco días después, le expresaba que "los profesores me piden mucho la planta, frutas, etc. de la cual los indios sacan su polvo para las mujeres (munra toctaci). Espero que pronto me mande todo, como se lo he pedido en una carta anterior". Nótese que, además de Polakowsky como contacto en Berlín, Thiel también había hecho gestiones en Washington, muy posiblemente con algún especialista del Instituto Smithsoniano, entidad con la que tenía cercanas relaciones, como se vio en páginas previas.

Según María Eugenia Bozzoli y Alí García - de origen bribri, y especializado en su lenguaje y su cultura-, los términos consignados por Thiel podrían corresponder a otros significados. Al parecer, el vocablo toctaci alude a un fragmento o al polvo de algo seco, en tanto que munra correspondería a múL $\underline{a}^{\prime}$. Bozzoli pudo averiguar que, en realidad, éste no es un árbol, sino posiblemente un musgo, un líquen o un hongo, pues se encuentra sobre rocas, debajo de los árboles, y es blanco y húmedo, así como suave al tacto. Ya preparado, el polvo 
obtenido tiene la consistencia y apariencia de la harina de trigo, y posee cierto sabor a canela. Los awápa o chamanes les dan a chupar a las mujeres una pequeñísima cantidad del polvo pues, de otra manera, podrían esterilizarlas de por vida o afectar seriamente otros órganos. Es importante aclarar que el material botánico no se consigue en Talamanca, sino en las partes más altas y rocosas de la serranía conocida como fila KuásúLLa o Kuasran, cerca de Boruca.

Este interesante episodio lo resumió así su biógrafo Sanabria (1941): "Entre los efectos científicos del viaje a Talamanca, en 1882, estuvo el descubrimiento que se hizo de los polvos usados por las indias para esterilizarse, polvo sacado de la cáscara de un árbol que se halló en la pendiente occidental de la cordillera de Talamanca". A continuación, en una nota al pie, indicaba que: "El Prelado tuvo la intención de hacer analizar por laboratorios en Berlín, algunas de las hojas y cáscaras de ese árbol, pero consultado el caso con la Santa Sede en 1884, y por razones fáciles de entender, no lo hizo". Es decir, ahí expiró su interés científico, por motivos obvios. Esto permite suponer que Liebreich ni siquiera recibió el material vegetal que había ofrecido analizar.

\section{La fauna en las crónicas de Thiel}

Antes de referirnos a la fauna mencionada en las crónicas de Thiel, es oportuno aclarar que cuando él arribó al país ya habían fallecido los dos zoólogos pioneros que residieron aquí, ambos médicos y coterráneos suyos: Karl Hoffmann y Alexander von Frantzius; el primero murió en 1859, mientras que el segundo retornó a Alemania en 1868 y murió allá en 1877. Sin embargo, von Frantzius formó al joven José Cástulo Zeledón Porras, quien después de realizar una pasantía de cuatro años en el Instituto Smithsoniano, a partir de 1872 se convirtió en nuestro primer ornitólogo y mastozoólogo (Hilje, 2013). Asimismo, hacia el final del siglo XIX e inicios del XX, surgirían los ya citados naturalistas Anastasio Alfaro y José Fidel Tristán, quienes se inclinaron tanto por la zoología como por la arqueología. Además, hubo dos zoólogos extranjeros que laboraban en el Museo Nacional, de los cuales el estadounidense Cherrie estuvo pocos años en el país, en contraste con el inglés Underwood, quien permanecería en el país hasta su muerte, en 1943. 


\section{Artrópodos fastidiosos}

De animales invertebrados, como es de esperar, en las crónicas de Thiel predominan las referencias a insectos molestos, entre los que destacan los mosquitos y los zancudos, con breves menciones de los tábanos, hormigas, avispas, piojos y comején, más las garrapatas, que no son insectos, aunque sí artrópodos.

Por ejemplo, en cuanto a los mosquitos, él narra que mientras estaban en las cercanías de Dominical, al suroeste del país,

\footnotetext{
"la marea nos permitió llegar a la quebrada de La Ballena, donde dormimos, si es que puede dormirse con los mosquitos que allí abundan. El 22 llegamos temprano a Punta Mala, donde tomamos enseguida los botes y continuamos subiendo el Río Grande hasta El Pozo, donde dormimos al descubierto, siempre inquietados por los inoportunos mosquitos".
}

Asimismo, siempre en ese sector, después acotaría que "la noche fue bastante buena, si bien los famosos mosquitos, verdaderas plagas de las costas, nos mortificaron un buen rato".

Por su parte, en relación con los zancudos, cuando trataban de descansar en un palenque indígena de Upala, acotaría que "había tantos zancudos que tuvimos que comer andando y casi todos quedamos sin dormir en esta noche", así como que "esta noche la pasaron casi todos sin dormir por la muchedumbre de zancudos, que no les permitía descansar un momento". Culminaría expresando:

“¡Qué noche, Dios mío! Nuestra cama, que era la dura tierra, estaba dispareja. Los pies más altos que la cabeza, las hormigas pululaban en nuestro colchón de hojas verdes; los troncos mortificaban nuestras costillas, y los zancudos con su espeluznante ji i! ji i! nos arremetían con todo furor".

A propósito de tan fastidiosos insectos, un hecho a resaltar es que, al referirse al uso del cacao por parte de los indígenas, indica que

\footnotetext{
"embadúrnanse también todo el cuerpo con la grasa del cacao para precaverse algún tanto contra los abrasadores rayos solares y para defenderse de los zancudos y de los mosquitos que sin tregua les persiguen, sin fijarse que aquella grasa paraliza casi por completo la transpiración cutánea".
}

Asimismo, como se indicó en páginas previas, Thiel indica que, durante la noche, el humo de la leña en los palenques mantenía alejados a los insectos molestos. 
Nótese que él hace una distinción clara entre mosquitos (familia Simuliidae) y zancudos (familia Culicidae), ambos dípteros, pero muy diferentes en su anatomía y taxonomía; en el primer caso, algunos consideran como mosquitos a las purrujas o jejenes (familia Ceratopogonidae).

Un caso que merece atención, aparece en un relato en Bitey, Talamanca, en el cual Thiel expresa que

"este rancho es, como la mayor parte, destapado por los lados y el fuego en medio. La mujer del indio tenía una fea llaga en una pierna, como las que se padecen en Talamanca, por efecto de las comidas y descuidada vida. No son-como algunos han supuesto- picada de mosquito, ni efecto del clima".

Esta afirmación tan rotunda de Thiel es errónea, pues esos síntomas de grotescas llagas sugieren claramente que se trataba de la leishmaniasis o lepra de montaña, causada por varias especies del protozoario Leishmania, transmitida por un mosquito bastante pequeño del género Lutzomyia (familia Psychodidae) (Zeledón et al., 2014).

Ahora bien, curiosamente no hay alusiones a chinches chupasangre (familia Reduviidae) ni a alepates o chinches de cama (familia Cimicidae), ni tampoco a alacranes o escorpiones, todos los cuales son frecuentes en domicilios con condiciones higiénicas paupérrimas, como las de los ranchos indígenas. Asimismo, no hay referencias a sanguijuelas -medio parientes de las lombrices de tierra-, que son hematófagas y habitan aguas estancadas.

Además, no se mencionan artrópodos que afectan al ganado, e incluso a las personas, como las niguas (Tunga penetrans), la mosca de tórsalo (Dermatobia hominis), la mosca de establo (Stomoxys calcitrans), el gusano barrenador (Cochliomyia hominivorax) y la araña picacaballo (Sphaerobothria hoffmanni). Hay apenas dos excepciones. En una ocasión, cerca de Boruca, Thiel señalaría que "en esta estación abundan por todas partes las garrapatas; centenares se prendían en mi cuerpo y todavía no se curan sus picaduras", mientras que el otro caso se refiere a las cercanías de San Isidro de El General, donde "la abundancia de tábano molesta mucho en todos estos puntos"; se ignora de cuáles especies podría tratarse, pues en Costa Rica hay casi 150 especies de esta familia (Tabanidae). 
Un caso interesante data de una ocasión en las cercanías del valle de Orosi, donde

"los guías, poco conocedores del camino, se extraviaron, llevándonos por un trillo de troceros y luego por un charral. Aquí don León hizo su agosto, pues unas benditas avispas correvenado se le arrancharon en la barba acariciándosela a pinchazos, lo que le sacó de sus casillas y le puso malhumorado, y algunos otros acompañantes recibieron igual demostración y aviso".

Según el entomólogo Paul Hanson, esta avispa podría corresponder a Parachartergus apicalis, P. aztecus o P. fraternus, que se caracterizan por poseer alas negras, con la punta blanca. Asimismo, cabe acotar que el individuo citado era el ya citado historiador León Fernández, quien acompañó a Thiel en varios de sus viajes. De hecho, su biógrafo Sanabria (1941) acota que, entre los intelectuales de la época, Thiel tuvo una buena amistad con Anastasio Alfaro y con Fernández, y especialmente con este último.

En otra oportunidad, mientras estaban en un palenque en Upala, él expresaría que

"los hombres no usan sombrero ni nada parecido que les resguarde la cabeza de los ardores del sol. Y tanto éstos como las mujeres, tienen el pelo en desorden sin que se preocupen por aprovechar los peines que Su Señoría les regala para limpiar y asear aquel criadero de piojos y liendres".

Aquí alude al piojo de la cabeza (Pediculus capitis) (Zeledón et al., 2014), cuyos huevos se denominan liendres.

Para concluir esta sección, cabe señalar que en una gira a Golfo Dulce, al visitar un templo abandonado, Thiel anotaría que

"durante un año había permanecido cerrado con 33 grandes nidos de comején, que habían comido y destruido las maderas, de tal modo que a cada momento el edificio amenaza ruina, nada hay en el interior: ni altar, ni cruz, ni ara, ni manteles, falta casi todo el piso antes construido con tablas de cedro".

En realidad, de los comejenes o termitas que viven en Costa Rica, solo Nasutitermes corniger hace grandes nidos con forma de bola, pero en árboles y no en edificaciones, lo que sugiere que los nidos observados por Thiel más bien correspondían a puntos del templo seriamente afectados, pero por otra especie, como Cryptotermes brevis. 


\title{
De moluscos y perlas
}

Aparte de los artrópodos citados en la sección anterior, las únicas otras menciones de animales invertebrados corresponden a moluscos, pero de manera muy superficial.

En efecto, en un relato referido a la región de Golfo Dulce, Thiel acota que

\begin{abstract}
"tomado el desayuno fuimos algunos a recoger ostras en un pequeño banco de ellas, que la vaciante iba descubriendo. Se recogieron algunos ostiones y conchaperlas, en cuya faena estábamos, cuando llegaron los mozos con las bestias de carga, a cosa de las nueve y media. Se preparó el almuerzo; y al comer Su Señoría Ilustrísima una tortilla hecha de los mariscos, halló dos perlas finas aunque muy pequeñas, menos que una fruta de güitite, las que regaló a la Virgen de Santa María, en recuerdo de haberlas pescado su cura".
\end{abstract}

El güitite (Acnistus arborescens) es un conocido arbusto, cuyos pequeños y redondos frutos son muy apetecidos por algunas aves.

En cuanto a los moluscos citados, quizás más bien se trataba de las otrora abundantes chucheca (Grandiarca grandis) o las pianguas (Anadara tuberculosa y A. similis), y no de ostiones. Por su parte, las llamadas conchaperlas corresponden a dos especies de moluscos bivalvos, también conocidas como concha de perla y madreperla; ellas son Pinctada mazatlanica y Pteria sterna, según el experto Mario Monteforte. Además del consumo de su carne, en la cara interna de cada valva o "tapa" hay una delgada capa de nácar, cuya dureza y bella iridiscencia permitía elaborar botones y hacer incrustaciones en objetos de lujo. Adicionalmente, en su interior se forman codiciadas perlas, de gran valor ornamental y económico, por lo que se exportaban a tal grado, que en 1854 el gobierno de Juan Rafael (Juanito) Mora Porras se vio obligado a emitir leyes para la protección de este importante recurso marino (Hilje, 2015).

Una evidencia del valor de estas perlas proviene del propio Thiel. En efecto, cuando en febrero de 1899 visitó la iglesia de la parroquia de Nicoya, se llevó una ingrata sorpresa. Después de oficiar misa, hizo un recorrido por el templo y la sacristía, y al inspeccionar los vasos sagrados (cáliz, custodia, copón, etc.) y los ornamentos, se percató de que a la custodia le faltaba la perla aguacate. La custodia u ostensorio es una hermosa pieza de oro, con un pedestal sobre el que se sustenta una parte redonda en medio de la cual hay una pequeña ventana -llamada viril-, que se abre mediante un delicado gozne, para depositar ahí la hostia tras ser consagrada. 
A propósito de esa gema, ya en 1853 los viajeros Wagner y Scherzer (1974) acotaban que "las especies más exquisitas que se encuentran en el Golfo de Nicoya se clasifican en Aguacates, Margaritas y Amarillas". A juicio del experto Monteforte, esta clasificación, basada en la forma, la coloración y el tamaño de las perlas, pareciera ser de uso local y no universal; en tal sentido la gema sustraída podría haber correspondido a una perla grande, con forma de aguacate y tono esmeralda.

Del comentario de Thiel no se puede discernir si había solo esa perla-incrustada quizás en la parte superior del viril-, o si estaba acompañada por otras de menor tamaño alrededor de esa estructura. Pero eso es poco o nada relevante, pues lo grave fue el acto sacrílego de mutilar ese objeto sagrado, además de la pérdida de tan valiosa joya.

Ello justificó que, de inmediato, él emitiera algo tan serio como un decreto de excomunión, el cual decía así:

\footnotetext{
"No habiendo encontrado en la visita canónica la perla aguacate, adorno de la custodia de esta parroquia y no habiendo podido hasta la presente averiguar el paradero de dicha alhaja, obligamos bajo la pena de excomunión ipso facto incurrenda a la persona que la tenga en su poder a que la restituya inmediatamente a la iglesia parroquial. Igualmente, obligamos bajo la misma pena de excomunión ipso facto incurrenda a todas las personas que sepan el paradero de la referida al haja, si, previa esta admonición una pro trina, hasta el lunes próximo 13 del presente mes de febrero, no declaran ante Nos, o ante nuestro secretario, o ante el señor cura de esta parroquia, lo que sepan sobre el asunto para hacer las averiguaciones del caso. Léase tres veces en la iglesia parroquia de Nicoya coram concursæ populi".
}

Se ignora si la perla sustraída fue recuperada.

\section{Vertebrados silvestres}

En cuanto a animales vertebrados silvestres, en las crónicas de Thiel no hay menciones de anfibios, y muy pocas de peces y reptiles (serpientes, tortugas, iguanas y cocodrilos). Eso sí, hay varias alusiones a aves y mamíferos, como se nota a continuación.

Para comenzar, en un relato referido a la región suroeste del país, en las cercanías de Parrita, se consignó lo siguiente: 
Revista Herencia, Vol. 33 (2), julio-diciembre, 2020.

"Salió de Pirrís a las 7.20 de la mañana. Poco antes de salir, el ilustrísimo señor Obispo mandó al padre Badilla que bendijera la costa y conjurara los animales nocivos. Todo lo cual se hizo conforme a lo mandado con el rito debido. [...] A las 4.15 salió al camino franco donde se acaba la montaña. Un compañero tocaba un caracol para avisar a los habitantes. Otro traía un mono tití que compró el padre [José] Badilla en 1.50 pesos".

\section{Esta especie de mono (Saimiri oerstedii) es la más pequeña de las cuatro que viven en nuestro territorio, muy gustada como mascota.}

\section{Ahora bien, en uno de los relatos alusivos a la región norteña del país, hay un pasaje de gran riqueza lírica, que dice así:}

“En este camino hecho al azar, al través del laberinto de espesas montañas en donde el gigantesco árbol caído nos obligaba a dar grandes vueltas, se nos presentaba un espectáculo arrebatador. El pitorreal con sus infinitos y variados gorjeos ahogaba en la garganta nuestras quejas, y todos los colores encantadores de aquel mundo volante y cantante nos llenaban de delicias. Algunos monos negros con la cara blanca, de rama en rama huían de nuestra presencia, mientras que el congo, perezoso animal, nos aturdía con sus mugidos que se repercutían en todos los ángulos de las montañas. [...] El sueño nos había sorprendido bajo las ramas frondosas de aquellos árboles gigantescos, en donde el pitorreal y el jilguero e infinidad de alados cantores, entonaban himnos arrebatadores al Supremo Hacedor ante los primeros rayos del sol naciente".

Y otro pasaje referido a esa zona, no menos poético, es el siguiente:

"El río Frío puede ser considerado como un camino fluvial abierto por la Providencia para el engrandecimiento y riqueza de aquella región. ¡Qué hermosa y fresca navegación presenta aquella corriente majestuosa y solitaria! Árboles rectos y gigantescos en cuyas ramas grita la oropéndola o se mete en su colgante nido, reflejan sus sombras sobre las ondas en donde el viento es fresco y agradable. Aquellas verdes florestas solo han sido violadas por el machete de unos pocos civilizados que viven en sus cercanías. Cañas salvajes crecen y se extienden en su orilla, mientras que grandes zacatales bordean el río, cuyas aguas de deslizan tranquilas y serenas como una corriente de aceite entre dos murallas de verdes bosques".

\section{Asimismo, durante un recorrido por el golfo de Nicoya. Thiel anotaría que}

"el vaporcito corría con velocidad mediana en momentos mismos en que los rayos solares disipaban las sombras de la noche, mostrándonos a uno y otro lado, las islas Ilenas de frescura y vegetación. San Lucas, Chira, Venado, Caballo, Bejuco... y las costas de Canjel cubiertas de eternas florestas, en un principio apenas perceptibles en el horizonte, pasan después ante nuestra vista. En sus riberas se ven las blancas garzas entretenidas en buscar el sustento de la vida, y que miradas sin atención parecían grandes ejércitos formados en escuadrones". 
De la fauna mencionada en los últimos párrafos, el nombre del jilguero, de espléndido canto, es Myiadestes melanops. En cuanto al pitorreal, según el ornitólogo Sandoval, en Costa Rica se denomina así a Ptiliogonys caudatus, pero es una especie de tierras altas, que no aparece en la cordillera de Tilarán o de Guanacaste, como para que pudiera descender a Upala; por tanto, es de suponer que más bien se trata del agüío (Euphonia gouldi), común en Upala y de canto parecido al primero. Por su parte, los monos corresponden al carablanca (Cebus capucinus) y al congo (Alouatta palliata), de poderoso y ronco aullido. Asimismo, las oropéndolas, que tejen inmensos nidos en forma de bolsas colgantes, podrían ser Psarocolius montezuma o P. wagleri, pues ambas están presentes en esa zona.

\section{Vertebrados de valor alimenticio}

En relación con animales vertebrados capturados o cazados para aprovechar su carne o sus huevos, en los relatos de Thiel hay apenas tres menciones de peces (bobo y tiburón) y unas pocas de reptiles (tortugas e iguanas), en tanto que son más abundantes las de aves (pavas) y mamíferos (saínos, tepezcuintle y monos). Sin embargo, como se verá pronto, los indígenas evitaban consumir la carne de venado por motivos religiosos o espirituales, al igual que la de danta, aunque en este caso por razones no tan claras.

Al referirse a la dieta cotidiana de los guatusos, Thiel acota que "su alimentación ordinaria consiste en las chichas de plátano maduro, de pejibaye y de yuca [...]. El plátano maduro o asado deshecho en agua, constituye su bocado favorito durante todo el día. La carne de monte y el pescado lo comen cuando buenamente los pueden conseguir". Y continúa, especificando que

\footnotetext{
"comen de todos los animales pequeños que hay en el monte. No comen el venado por la creencia de que en él está el alma de un difunto penando. No comen su carne y huyen de la danta lo mismo que de todo animal grande. La carne de res no la comen tampoco porque creen ser de la familia de la danta, y porque temen les salgan cachos. Son platos exquisitos para ellos el mono y el garrobo".
}

En palabras del cronista, "por comerse una iguana (toro ifa) o un mono (tiu) asados con todo y tripas sobre las brasas, son capaces de dar hasta un ojo de la cara". 
Acerca de la carne de venado (Figura 10), que es realmente deliciosa, el extinto especialista Adolfo Constenla Umaña, experto en la cultura y el lenguaje guatusos, en el prólogo del libro de Zeledón (2003) aclara que lo indicado por Thiel no es veraz. Dice él: "Igualmente, es cierta la información recogida según la cual estos indígenas no comían carne de venado (la mayor parte de ellos todavía no la come), pero no la interpretación", para después aclarar que la evitan "porque los dioses declararon inmunda la carne de los venados".

Figura 10. El supuestamente incomible venado cola blanca.

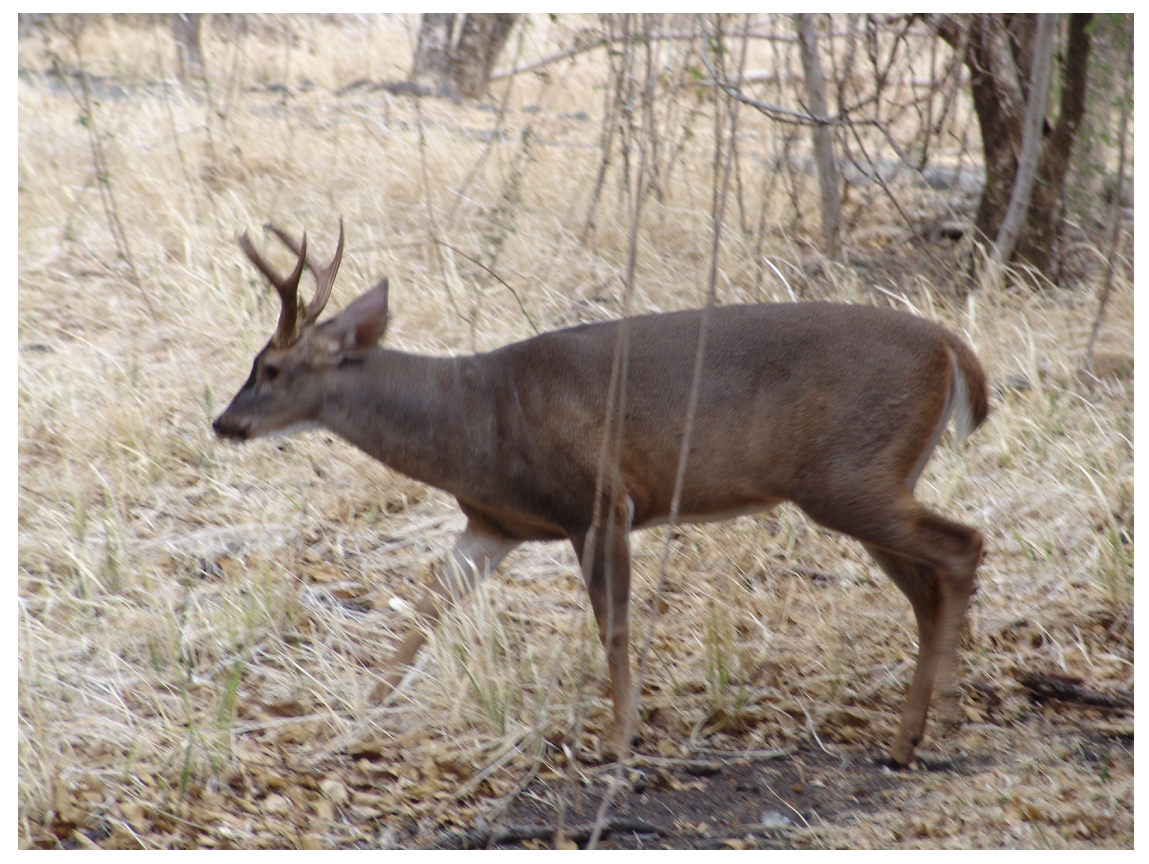

En relación con la demás fauna comestible, las dos menciones de peces corresponden al bobo (Joturus pichardi) (Figura 11A), de carne muy apetecida. En efecto, eso ocurrió en el río Sharai o Sharra, en la actual Moravia de Chirripó, donde "los indios se fueron a pescar y trajeron cuatro bobos hermosos", en tanto que, en otra ocasión "el indio [Francisco] López y su familia se habían ido a pescar y volvieron como a las 3 de la tarde con unos diez bobos". Por su parte, la segunda mención aparece durante un recorrido por río Frío, al norte del país, donde Thiel alude a una especie de tiburón de agua dulce, a la cual se hará referencia posteriormente. 
Siempre en la región de Upala, Thiel señala que los guatusos "son muy amantes de la pesca y tienen cuatro métodos para proporcionarse tan exquisito bocado", pero narra solamente tres, además de que no indica las especies de peces que capturaban. En esa zona, además del bobo, son comunes y gustados el guapote (Parachromis dovii), las machacas (Brycon spp.) y las viejas (Tomocichla spp.) (Bussing, 1987).

Al respecto, él explica que

"el primero consiste en el ataque personal que el indio hace al pez en su propia morada, que tienen en los huecos de los paredones del río. Consúmese el indio en el agua, mete la mano en la cueva, coge lo que toca y sale con su presa, no siendo raro que saque una culebra en lugar del apetecido pez".

Figura 11. Los muy apetecidos bobo (A) e iguana rayada (B).

A.

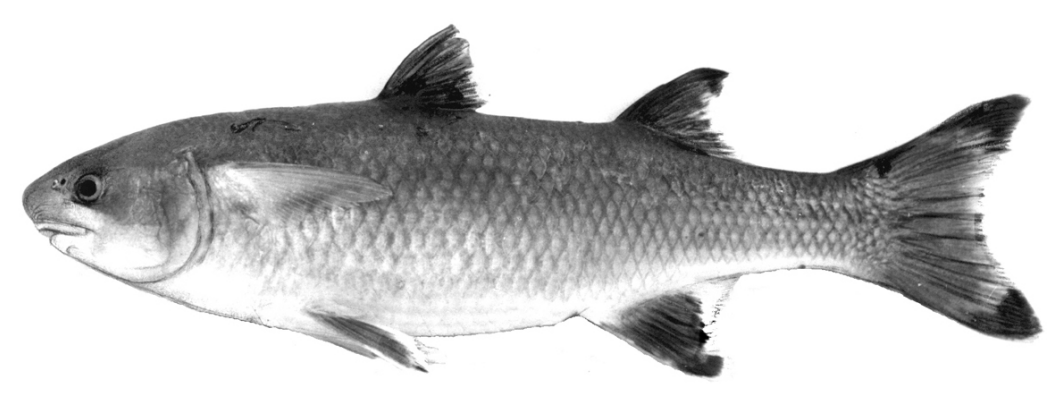

B.

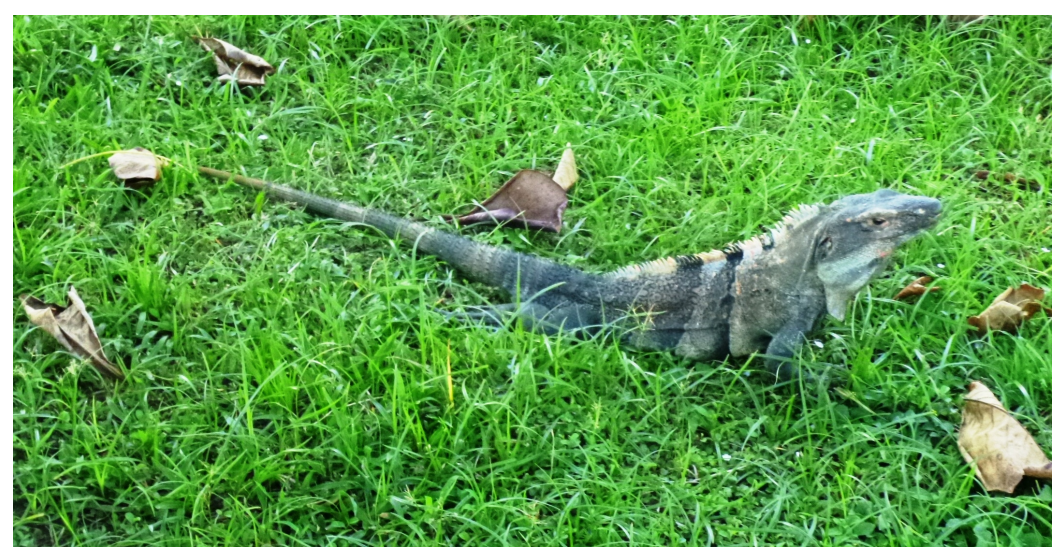


Por su parte, "el segundo consiste en flechar el pez desde la orilla del río, arrojándose al agua a sacarlo junto con la flecha", confeccionada con los materiales descritos en páginas previas. Asimismo,

"el tercer método consiste en el uso del anzuelo, cuya utilidad no conocieron sino hasta que nuestro caritativo Pastor empezó a civilizarlos. Antes de conocer el anzuelo amarraban en el extremo de una cuerda una varita pequeña y delgada, sobre ésta colocaban un pedazo de [plátano] maduro que envolvían en cuerdas muy finas de mastate. Arrojábanlo al río, el pez mordía y sin darle tiempo de soltarse, tiraban con fuerza de la cuerda botándolo en tierra con solo el impulso".

En cuanto a reptiles, hay unas pocas sobre iguanas o garrobos, sobre todo como fuente de carne, lo que hasta hoy es usual en algunas comunidades rurales; en Costa Rica existen dos especies, la iguana rayada (Ctenosaura similis) (Figura 11B) y la iguana verde (Iguana iguana), ambas gustadas por su carne. Por ejemplo, en una oportunidad, en Upala, se narra que

"los indios ya vestidos, formaban un cuadro digno de describirse. Todos se alojaron en un gran palacio, un rancho sin paredes y allí pidiendo por todo el pueblo consiguieron ollas en qué cocinar plátanos verdes; lo demás, como leña, agua, iguanas, etc. fueron en partidas a proveerse al río. A las dos horas todo estaba pronto. La olla hervía con una iguana dentro, entera como Dios la creó y unos plátanos. No hubo hora de comer, cada uno fue pidiendo al cocinero: uno el rabo, otro las patas y se fueron repartiendo el contenido".

Asimismo, en una referencia previa se alude al uso de las iguanas como canje por otras mercaderías, al expresar que los indios guatusos

"hoy todo lo tienen: ropa, la que Dios les dio; comida les dan sus abundantes platanares y sus ríos poblados de rico pescado, y sus montes de caza pequeña. Una necesidad se advierte en ellos y es el cuero de iguana en que abunda el pueblo de Las Cañas, y ya hay indios que vienen con una carga de hule por dos iguanas hasta este pueblo".

Además de la gustosa carne, de las iguanas se aprovechaba su piel para confeccionar un instrumento de percusión, como lo revela el siguiente pasaje, referido a una festividad:

"El canto es seguido y aburridor, durando ese fastidio todo el día, en medio de sus borracheras. Aquellas melodías consisten en gritos fuertes que se van debilitando y prolongando hasta imitar el canto del gallo de la Pasión. No tienen ahora ningún acompañamiento de instrumento, ha desaparecido entre ellos el uso del tambor que llaman tali. Lo hacían este de la piel de la barriga de la iguana bien tendida sobre el hueco de una calabaza grande o sobre un aro de madera, aumentando el ruido con la concha del armado que rascaban con hueso o pedazo de madera de pejibaye". 
Nótese también el uso del caparazón de un armadillo para emitir sonidos. Esta es la única referencia a este animal, representado en Costa Rica por dos especies (Dasypus novemcinctus y Cabassous centralis), que posiblemente era también una fuente de carne de monte.

Ahora bien, en relación con tortugas, en Morro Hermoso, cerca de Santa Cruz, Guanacaste, Thiel atestiguó que "la playa se encuentra llena de huellas de tortuga y esta misma noche los mozos de la hacienda cogieron bastantes huevos"; se trata de la tortuga lora (Lepidochelys olivacea), que forma inmensas arribadas en el litoral Pacífico. Por su parte, en la costa del Caribe, en las proximidades de Puerto Limón, acotaría que "industria no hay otra más que la pesca de la tortuga carey, el coco silvestre [y] el caucho en pequeña cantidad"; del caparazón de dicha especie (Eretmochelys imbricata) se obtenía el carey, fino y duradero material de diversos usos. También indicaba que los guatusos "una vez al año y en gran número, bajan en balsas las aguas del río Frío en busca de la tortuga, que consideran como un alimento exquisito"; esto se puede interpretar como que ellos tomaban después el río San Juan, para dirigirse a la costa del Caribe, donde entre junio y octubre hay grandes arribadas de la tortuga verde (Chelonia mydas), de la cual se aprovechan los huevos y la carne, por ser muy grandes.

En relación con piezas mayores de cacería, en una referencia acerca de un paraje de Talamanca, Thiel señala que "hay mucha caza, sobre todo de gallinas y pavos salvajes", para después manifestar que un domingo, después de celebrar misa, "a poco de haber salido tuvimos la suerte de cazar un pavón, la más grande y gustosa de nuestras aves de caza. A las 10 a.m. habíamos terminado el descenso y almorzábamos en la margen izquierda del Tocorí". Asimismo, en la zona de Golfo Dulce, anotaría que "nos pusimos en marcha, pasando el río Sabalito y Balsar. Hasta aquí todo es llano, monte hermoso, y muchísimo hay para cazar: pavos, pavones y saínos, cabros, más de lo que los indios querían".

De estas aves, según el ornitólogo Sandoval, el pavón es Crax rubra, y el pavo es Penelope purpurascens, mientras que la citada gallina de monte podría corresponder ya sea a las codornices del género Odontophorus, o a otras tres 
especies: la gongolona o tinamú grande (Tinamus major) y el yerre (Crypturellus soui) en las tierras bajas y hasta $2000 \mathrm{~m}$ el primero, mientras que el tinamú serrano (Nothocercus bonapartei) vive a partir de $1500 \mathrm{~m}$. En cuanto a los mamíferos, el cabro de monte es Mazama americana; por su parte, el verdadero saíno es Pecari tajacu, pero podría tratarse también del cariblanco o chancho de monte (Tayassu pecari), pues ambas están presentes en casi todo el territorio nacional (Carrillo et al., 1999). Al tepezcuintle (Cuniculus paca), roedor de deliciosa carne, se había aludido en páginas previas.

A propósito de animales, durante su primer recorrido por la región de Upala, en cuya comitiva figuraban Ernesto y Jenaro Pinto, jóvenes oriundos de Grecia, Thiel consignó

\footnotetext{
"desde las 10 en adelante se aclaró el día. A las 11 encontramos los primeros trillos de los indios, probablemente veredas o caminos de caza. Uno de los jóvenes Pinto tiró un saíno, que acosado por los perros se lanzó sobre el camino por donde todos venían; pasó entre los pies del señor Obispo, recibiendo varios machetazos de parte de los soldados. En poco rato encontramos un rancho en donde almorzamos con carne fresca".
}

Pero lo cierto es que los indígenas guatusos llegarían a dominar el uso de armas, con fines de cacería.

Eso lo atestiguó el propio Thiel, al manifestar que

\begin{abstract}
"la pólvora reemplazó a los hoyos de caza que hacían en el suelo y tapaban con hojas, con tanto cuidado que era difícil distinguirlos y fácil caer en ellos. Durante el camino del río Cucaracha al palenque Tojifo, encontramos ocho abandonados y colocados en la orilla del trillo o bajo los árboles de ojoche, cuya fruta buscan los cariblancos y otros animales montaraces. A veces colocaban dos a la par y casi unidos, midiendo por lo general cuatro varas de profundidad, de donde no podía salir el animal que en ellos caía. En el fondo clavan unas estacas para asegurar más al animal, que herido tenía menos fuerzas para saltar".
\end{abstract}

Pero, también, Thiel agrega que "de esta manera lograban coger al tigre y al león", como se ha llamado de manera errónea al jaguar (Panthera onca) y al puma (Puma concolor) desde la época de la conquista española. Cabe acotar que el nombre científico del ojoche es Brosimum alicastrum. 


\section{Vertebrados molestos o peligrosos}

Entre los animales vertebrados molestos o peligrosos, destacan los murciélagos, las serpientes venenosas, los felinos y los chanchos de monte.

De los primeros, mientras estaba en la iglesia de Bagaces, Guanacaste, Thiel advirtió que "conviene no descuidarse en perseguir los murciélagos que otra vez se han metido, causando bastante daño en la ropa de los altares". Igualmente, en Orosi, Cartago, señalaba que "ha de tomarse mucho interés en destruir la plaga de murciélagos que causa mucho daño en la iglesia y la sacristía", mientras que en Pacaca, San José, recomendaba que "han de ponerse en el cielo raso de la nave principal ventiladores, para la renovación del aire y que sean tales, que no dejen entrada a los murciélagos". En los tres casos, es obvio que se refería a daños causados por los excrementos de especies frugívoras o nectarivoras, que usaban los templos como sitios de descanso. En ninguna de sus crónicas hay alusiones al vampiro (Desmodus rotundus), que es la única especie hematófaga en América, por lo que afecta mucho al ganado, e incluso puede transmitir el virus de la rabia paralítica bovina a las personas.

En cuanto a serpientes, al referirse a los indígenas guatusos, Thiel señala que ellos "viajan muy poco, y cuando salen van siempre acompañados, medida muy prudente en lugares expuestos a las mordeduras de las culebras".

En una ocasión, acotaba que un colono estadounidense que se había establecido en las cercanías del palenque Margarita, "distraído, sin duda, se extravió internándose -sin notarlo- en la montaña, donde temíamos hubiese sido devorado por el tigre o matado por alguna culebra venenosa de las que por ahí abundan". En otra oportunidad, uno de los ayudantes de Thiel consignó que "antes de irnos recorrimos el palenque con Su Señoría, dando consuelo y medicinas a los enfermos, entre ellos a un picado de culebra que poco a poco se le iba secando el cuerpo", a la vez que indicaba que "no sé si habrá algo de cierto, pero ellos aseguran que cuando comen en ayunas la manteca del cacao, no tiene ningún efecto en su cuerpo la mordedura de la serpiente, por venenosa que ésta sea".

Por su parte, en una de sus visitas a Talamanaca, Thiel expresó que

"proverbial es la abundancia de serpientes venenosas en estas montañas, que a menudo ceban su furor en las enfermizas carnes de nuestros pobres indios. Curiosos son los ritos indispensables, cuando un nativo es víctima de los agudos colmillos del inmundo animal, que para ellos es emisario de orosique (diablo)". 
Narra ese complejo ritual que, según uno de sus colaboradores residente ahí, "va cayendo en desuso. Muchas veces acuden al comandante o a mí, en busca de remedio; felizmente tengo buen surtido de la preciosa curarina que administrada gratis, ha salvado a más de un mordido de toboba". A este supuesto remedio natural se hará alusión posteriormente.

Sin embargo, llama la atención que en las crónicas de Thiel haya apenas dos referencias a especies de serpientes en particular. La primera corresponde al territorio indígena de Shiroles, y dice así: "a las 2 de la tarde estábamos en la casa de Justo. Llegamos a tiempo de auxiliar en esta casa a un peón enfermo de picada de culebra coral". Según el herpetólogo Alejandro Solórzano, en esa zona hay cuatro especies de corales, dos coral gargantilla (Micrurus mipartitus y M. multifasciatus), la coral costarricense ( $M$. mosquitensis) y la coral gigante de agua (M. alleni) (Figura 12A); él aclara que los accidentes con corales son raros, y aunque su veneno tiene un efecto neurotóxico, su acción es retardada, lo cual explica lo narrado por Thiel, mientras que los venenos hemotóxicos -es decir, que provocan hemorragias, como el de la terciopelo y todos los vipéridos o tobobas- actúan en forma inmediata.

En el segundo caso, en las cercanías del río La Estrella, acota que

\footnotetext{
"a las 5 de la tarde llegamos a Cacharva. Hoy escapó uno de los borucas de ser mordido de una toboba grande. El indio venía casi el último, irritada la toboba por el ruido que habían hecho los primeros transeúntes, saltó furiosa contra el indio, felizmente agarró la carga que el indio llevaba en el hombro".
}

Según el mismo herpetólogo, ninguna culebra tiene la capacidad de saltar, y más bien podría haberse tratado de una bocaracá (Bothriechis schlegelii) (Figura 12B), que es arborícola, y desde su posición en un árbol podría causar un accidente en las partes altas del cuerpo de una persona.

Ahora bien, en relación con felinos, en una ocasión narraría que "por fortuna, ni una sola gota de agua cayó durante aquella noche tranquila, solo perturbada por los rugidos de un tigre en acecho". Por su parte, en un recorrido por Talamanca, expresaría que "sin perder tiempo nos extendimos en el camino para descansar y pasar la noche [...]. Hoy se enfermaron varios indios durante la travesía del Dului, y todos quedamos muy cansados; los tigres y los saínos nos asustaron también durante la marcha". Aunque los grandes felinos, como el jaguar y el puma, normalmente no atacan a las personas, son muy temidos, en tanto que las dos especies de chanchos de monte sí forman manadas muy agresivas (Carrillo et al., 1999). 
Figura 12. Una coral costarricense (A) y una bocaracá (B).

A.

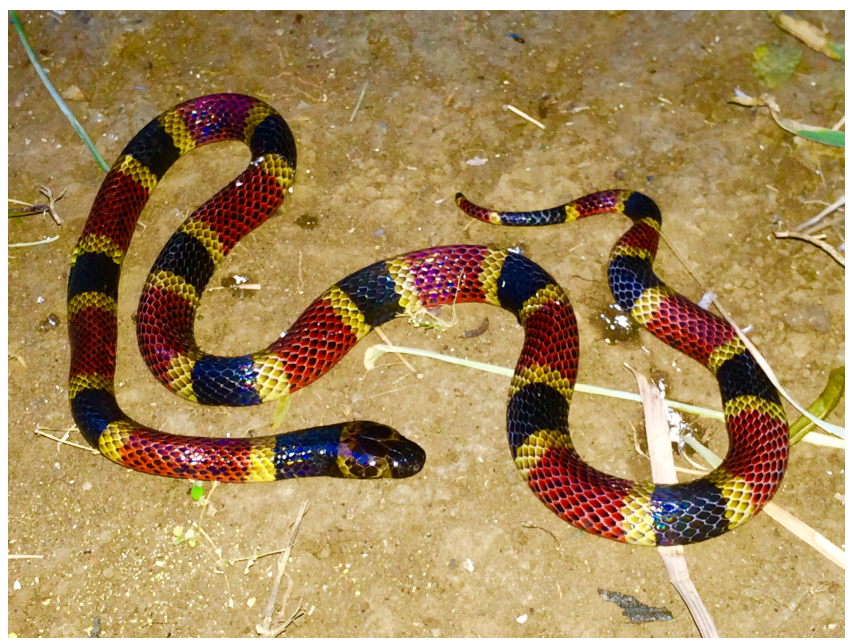

B.

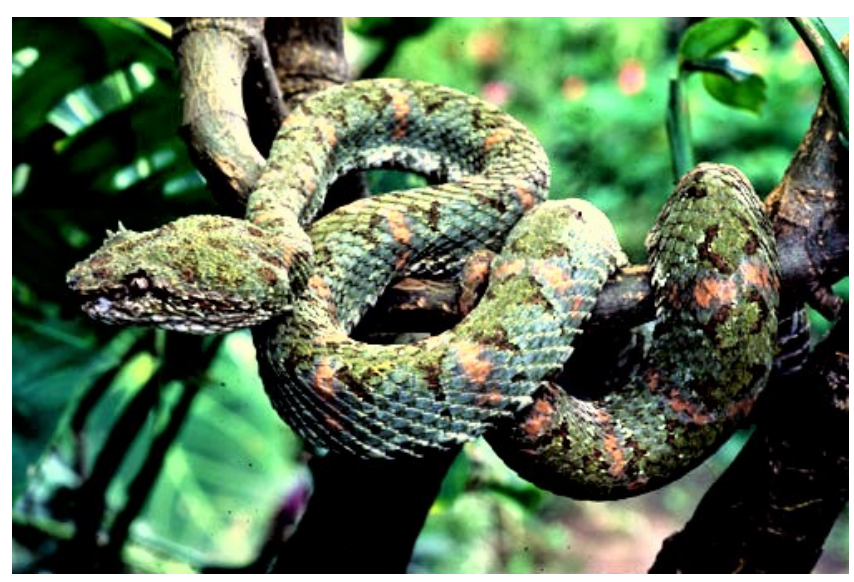

Fotos: Alejandro Solórzano.

Eso sí, los citados felinos sí pueden representar un serio problema como depredadores del ganado que está cerca de las áreas boscosas, de lo cual dan fe los siguientes testimonios de Thiel. En Talamanca, no muy lejos de Turrialba, atestiguaría que "los indios viven, la mayor parte, en la inmediación del río; en sus orillas tienen sus platanares, etc., pero también sus montes sembrados con plátano, frijoles, etc.; en otros lugares plantan café, ganado hay en Moravia alguno; en Chirripó casi desapareció por el tigre"; asimismo, diría que "en el curso de la misión, vino uno de Estrella que yo conocía, con mucho temor de los leones y tigres que andan en las cabeceras". Más al sur, en Boruca, expresaría que 
"el viernes en la mañana Su Señoría visitó personalmente la hacienda de San Francisco, que consiste en algunas cabezas de ganado vacuno, donadas a los fondos por particulares, y que, en Térraba como en Boruca, constituyen los fondos de la iglesia. Actualmente se hallan muy disminuidas, ya por el tigre, ya por otras causas".

Finalmente, en cuanto a otra fauna peligrosa, mientras estaba en Upala, Thiel apunta que "aunque no vimos ninguno, nos dicen que en ambos ríos abunda el lagarto de cuerpo largo y de patas cortas, como también el tiburón hambriento y atrevido. Aquí un Martín peña de golpe saca su presa en el pico, y allá en un tronco caído se sumerge un perro que llaman de agua". El citado lagarto es sin duda el cocodrilo (Crocodylus acutus), inmenso y muy común en esa región; la otra especie presente en el país es el caimán o guajipal (Caiman crocodilus), mucho más pequeño. En cuanto al tiburón, en el río San Juan es algo frecuente el tiburón toro (Carcharhinus leucas), que aunque prefiere los ambientes marinocosteros, está adaptado para vivir en agua dulce por períodos prolongados. Por su parte, no debe confundirse al martín peña (Tigrisoma mexicanum), que es una garza algo grande, con las varias especies de martín pescador, aunque todas se alimentan de peces. En cuanto al perro de agua o nutria (Lontra longicaudis), es un consumidor de peces, crustáceos, moluscos y anfibios (Carrillo et al., 1999).

\section{Los animales como símbolos}

En contraste con las plantas, la fauna tiene una fuerte presencia en los símbolos de varias de nuestras etnias indígenas, y eso lo atestiguó Thiel, aunque no profundizó en su importancia o su significado.

La única referencia hallada en relación con plantas es la de un acto ejecutado en Talamanca por un usékar, que es un gran sacerdote o gran brujo, a quien le pidieron

\footnotetext{
"que soplara sobre el padre [Manuel] Hidalgo para que se fuera del país o se enfermara. [...] Según sus creencias, el usécar tiene una gran cueva (que nadie ha visto y solo él sabe el lugar en donde existe); en ella ora para pedir a Dios lo que necesitan y luego trae la flor de la balsa o de otra hierba venenosa, o también por medio de un guacamayo o gallo desplumado, si no es posible darle el veneno a la persona. Después del hecho, resulte o no lo que pretende, cobra de cada vecino lo que le pueda dar, como ropa, animales, abalorios, cuentas y otras cosas que con mil trabajos han podido conseguir".
}

Ahora bien, en cuanto a esculturas, durante uno de sus recorridos por el sur del país, Thiel narró que 
"a las 5 de la mañana llegamos a El Palmar. Inmediatamente se fue Su Señoría Ilustrísima con tres a visitar un lugar a dos leguas de distancia, llamado Las Pilas, en donde se encuentran grandes piedras de los antiguos indios. Encontró cuatro ídolos de piedra de dos varas, uno entero y tres en partes; tres figuras de animales de cuatro a cinco quintales de peso cada piedra. Simbolizan venados o dantas o cariblancos".

En cuanto a ornamentos para el cuerpo, cuando visitaba esa zona, expresaría que "los habitantes se habían construido ranchos provisorios y estaban en una fiesta, tenían sus coronas de plumas en la cabeza y cadenas de dientes de tigre en el cuello. La chicha les había hecho muy alegres", mientras que de la región de Upala diría que

"aquí usan los indios, como adorno en el cuello, unas gargantillas de colmillos de animales caninos y uñas de tigres, pizote y ardillas, que les dan un aspecto más salvaje. No tienen nada de oro, y todo su lujo consiste en los mencionados collares y las plumas de aves que se ponen sobre la cabeza, prefiriendo siempre las coloradas del guacamayo".

A propósito de las guacamayas o lapas, hay dos especies, la verde (Ara ambigua) y la roja (Ara macao) (Figura 13), y esta última era parte del ritual de los entierros, al punto de que

"con cantos tristes y gemidos profundos llamaban el alma del difunto para que viniera a presenciar aquella celebridad. [...] Cuando suponían gratuitamente que esta ya había correspondido a su llamamiento, cuatro indios bien adornados con plumas de colores, colocaban el cadáver sobre sus hombros y se dirigían al lugar preparado al efecto. [...] Llegados al sepulcro le colocaban ahí y principiaban de nuevo los lamentos y gemidos con más fuerza que al principio; después al lado del cuerpo, ponían sus flechas, si era hombre, todos sus utensilios, y una guacamaya, cuyas plumas, decían, les serviría para adornarse en la otra vida".

Figura 13. La emblemática guacamaya roja.

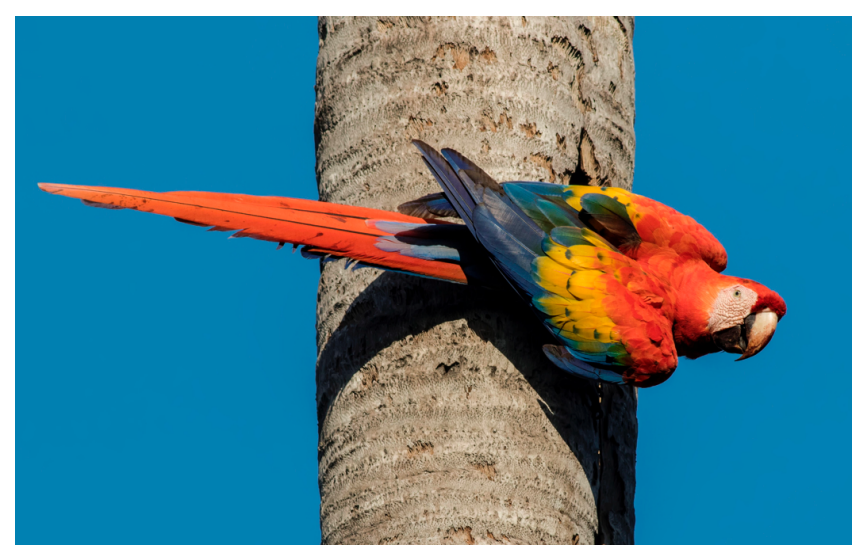

Foto: Guillermo Saborío. 
Los nombres científicos de las demás especies citadas en los últimos párrafos son: Ochroma lagopus (balsa), Odocoileus virginianus (venado cola blanca), Tapirus bairdii (danta) y Tayassu pecari (cariblanco o chancho de monte), Panthera onca (tigre o jaguar), Nasua narica (pizote) y Sciurus spp. (ardillas).

No obstante, hay algo de más fondo, pues se refiere a la fauna en la cosmovisión de los indígenas. Así, cuando Thiel estaba evangelizando en Talamanca y preguntó a los indígenas cuál era su visión de la creación del mundo, anotó lo siguiente: "No querían decir nada al principio, pero viendo el modo cariñoso con que les preguntaba, uno de los más ancianos que tenía un doble collar de colmillos de tigre y a quien todos -como se notaba-tenían cierto respeto, se animó y parándose en medio de todos frente a Su Señoría" manifestó que

\footnotetext{
"según la doctrina que le habían enseñado los ancianos, en toda la tierra no había habido al principio más que grandes pedrones (hac, hac) y extendió el brazo hacia los cuatro puntos cardinales diciendo: Hac, hac, hac, hac; y que así había sido mucho, mucho tiempo, hasta que un murciélago muy grande salió de entre las piedras y voló al cielo y quedó suspenso en los aires. De sus excrementos que cayeron sobre la piedra, había Dios formado la tierra vegetal, creando las plantas, árboles y todo lo demás".
}

Es oportuna una digresión aquí para destacar una contradicción en uno de los párrafos recientes. Al respecto, llama la atención que los indígenas cazaran y consumieran el cabro de monte (Mazama americana), pues es un cercano pariente del venado cola blanca (Odocoileus virginianus), el cual evitaban comer. Sin embargo, esta discrepancia podría ser tan solo aparente, pues en otro de los relatos de Thiel se indica que "llegamos a Psarábata (Alto del Biscoyol) en donde vive el curandero o ahoa de los estrellas. Es un indio anciano, astuto y desconfiado. Su mujer ya muy anciana, es muy hábil para cazar venado con la soga. Nos vendieron dos cuartos de venado, y nos recibieron bien con plátanos y chicha".

Esto hace suponer que el venado no significaba lo mismo para los guatusos que para estos indígenas del sur de Costa Rica -los estrellas-, quienes lo consumían sin reticencia; según el antropólogo Fernando González éstos eran bribris residentes en la región del río La Estrella. Al respecto, Pittier (1938) indica que

\footnotetext{
"los bribri cuentan que si cuando una persona mata un venado, corre a juntarse con él tan pronto como cae, puede encontrar entre sus pezuñas una piedrita blanca, y el que posee esa piedrita se topa entonces en todas partes con rebaños de venados, los que puede cazar según quiera y hasta el día en que el rey de la venados lo cace a su vez y lo mate".
} 
Esta última acotación obedece a que el venado, al igual que la danta y el chancho, supuestamente tienen reyes que los protegen, cuya anatomía Pittier describe en detalle.

\section{Thiel y el ofidismo}

En páginas previas, se consignó la preocupación de Thiel por las mordeduras de serpientes en varias de las comunidades que visitó y, en particular, en pueblos indígenas. En concordancia con esto, debe haberse sentido muy contento cuando algunos pobladores rurales le mostraron un helecho con supuestas propiedades antiofídicas.

Por tanto, él recolectó algunas muestras de esta planta y las remitió a los médicos Carlos Durán Cartín y Daniel Núñez Gutiérrez, acompañadas de una misiva que, fechada el 31 de agosto de 1883, decía:

\footnotetext{
"Les envío a ustedes algunos ejemplares de una planta (helecho) que se encuentra en las regiones altas de Costa Rica, ordinariamente en los árboles llamados güitite. / La infusión de esta planta, arreglada al modo de la infusión del té de la China, según lo aseguran los vecinos, cura la mordedura de la culebra toboba. En San Carlos se curó un hombre radicalmente hace dos meses. Las circunstancias de descubrir esta planta, ahora sería largo referir. / He examinado las cualidades de esta planta, juzgarán si es efectivo lo que se dice de su fuerza medicinal".
}

Sin embargo, no se limitó a esto, sino que dio un paso más allá, para lograr que le identificaran la especie, pero no era una labor sencilla, dado que para entonces no había botánicos en el país; Pittier y Tonduz arribarían en 1887 y 1889, respectivamente. Fue por ello que pocos meses después envió ejemplares del helecho a EE.UU. y Europa, como se verá pronto en una carta de él. Por fortuna, esa especie ya era conocida en el mundo científico, pues en 1841 la había recolectado el naturalista austríaco Emanuel von Friedrichsthal en Costa Rica o Nicaragua, donde estuvo muy activo; se ignora si éste o alguien más lo remitió al taxónomo alemán Gustav Kunze, quien en 1850 lo bautizó como Polypodium friedrichsthalianum, en honor a su recolector.

Acucioso como era, Thiel envió a Berlín las muestras solicitadas, junto con el polvo "munra toctaci", al cual se aludió en páginas previas. Para ello se valió de su amigo Polakowsky como intermediario. Así se colige de una carta de éste, que data del 4 de febrero de 1884 (AHABAT, I. 276, t. 1, f. 337-338), en la que le 
comunicaba que la planta era un polipodio, es decir, un tipo de helecho; aunque en la carta no figura el nombre Polypodium friedrichsthalianum, es posible que Polakowsky o algún otro taxónomo la identificara, por comparación con los especímenes depositados en algún museo europeo. Asimismo, le comentaba que había contactado al ya citado fitoquímico Óscar Liebreich, quien sí se entusiasmó mucho y ofreció colaborar.

En la citada carta, Polakowsky le hacía algunas preguntas a Thiel, según él muy importantes para la investigación científica. Una era si los indígenas empleaban la planta como polvo o como extracto alcohólico; si el extracto se utilizaba por vía interna, en una formulación acuosa o alcohólica, o si se lavaba con él la herida, o las dos cosas a la vez; y si la planta se usaba de manera preventiva, como preservativo, en vez de ser utilizada por la gente (como, por ejemplo, junto con el extracto de la semilla de Simaba cedron) o se usaba solo en caso de mordedura.

Asimismo, Polakowsky le indicaba a Thiel que Liebreich necesitaba $250 \mathrm{~g}$ adicionales del producto, y que si se obtuvieran resultados interesantes haría falta más material. Los costos implicados en la recolección y envío serían cubiertos con fondos del laboratorio de Liebreich, quien estaba dispuesto a valerse de su prestigio para interesar en este asunto al Ministerio de Relaciones Exteriores. Además, puesto que también deseaba examinar el veneno, le pedía enviarle dos ejemplares completos de la toboba, preservados en alcohol, así como unas seis u ocho cabezas secadas al sol o junto a un horno caliente; debía remitir éstas en seco, en una caja de metal (una caja de conservas vacía) que contuviera una pequeña cantidad de ácido carbólico vertido sobre pelo de oveja, algodón o heno.

En síntesis, el muy reputado Liebreich se ofrecía no solamente a efectuar un análisis de la composición química del helecho -que es una labor bastante compleja-, sino además a realizar experimentos que permitieran verificar si algunos preparados o extractos del helecho podían contrarrestar o inhibir el efecto del veneno, para lo cual necesitaba las moléculas tóxicas.

Entusiasmado por tan valioso apoyo, y con la diligencia que lo caracterizaba, Thiel actuó casi de inmediato. Por tanto, en una efusiva carta al ya citado ministro Castro Madriz, fechada en San José el 3 de abril 1884 y suscrita por "Bernardo Augusto, Obispo de San José de Costa Rica", expresaba: 
Revista Herencia, Vol. 33 (2), julio-diciembre, 2020.

"Excelentísimo Señor: En mis visitas pastorales que hago en todo el territorio de nuestra República, he fijado siempre mi atención en aquello que podía ser de interés general y causar algún beneficio a la humanidad. Entre varias cosas, he encontrado hace año y medio una planta medicinal que es el contra-veneno de la mordedura de la toboba. Cada año mueren en todo el territorio de esta República cincuenta personas más o menos, a consecuencia de la mordedura de esa culebra. El año pasado supe en San Carlos de varias curaciones sorprendentes debidas a la aplicación de una planta desconocida. Supe además, que a un individuo del Naranjo de Grecia, había curado durante mucho tiempo la mordedura de la culebra con la misma planta. Según datos que he recogido, viene la noticia de las cualidades medicinales de la referida planta, de los indios. Me interesé mucho en conseguirla y la he distribuido entre varios médicos, tanto de la capital como de las provincias.

La planta es conocida en la ciencia, y se llama Polypodium friedrichsthalianum Kre [Kunze]. La planta se ha encontrado hasta ahora en la parte fría de la cordillera, desde San Ramón hasta la Carpintera. Con el fin de obtener un resultado seguro sobre la planta, he enviado a fines del año pasado, varias cantidades a los centros científicos de Europa y de los Estados Unidos, para interesar a los hombres científicos y llamar su atención sobre ella. Últimamente he recibido contestaciones muy satisfactorias, especialmente del Profesor Dr. Óscar Liebreich, Director del Instituto Farmacológico y del Laboratorio Químico Fisiológico de Berlín. Este Profesor ha hecho en persona el análisis químico de la planta, y se ha interesado vivamente por ella, en vista de los resultados obtenidos. Ahora me pide, con el fin de completar sus estudios y de examinar el veneno mismo de la toboba, varios ejemplares de esta culebra conservados en alcohol, y unas diez o doce cabezas secadas al sol y conservadas en tarros de lata entre algodón impregnado de ácido carbólico.

El vivo interés que tengo de hacer un bien a Costa Rica y a la humanidad en general, encontrando el contra-veneno de la mordedura de la culebra que anualmente nos impone el sacrificio de tantas vidas, me ha impulsado a dirigirme a V.E. [Vuestra Excelencia] como Ministro de Beneficencia, para que se sirva procurar que los Gobernadores de provincias y los jefes políticos, valiéndose de su influencia, consigan a la mayor brevedad lo que el Profesor Liebreich quiere. Estoy dispuesto a pagar los costos que ocasione la cogida de estos animales. He interesado igualmente a los Señores Curas en el mismo sentido.

Entretanto conviene que en todas partes en donde se encuentra frecuentemente la toboba, como en las haciendas de la vía férrea al Atlántico, tengan esta planta medicinal para aplicarla en caso de mordedura sin perjuicio, naturalmente, de recurrir a los remedios hasta ahora conocidos. Tengo en mi casa una pequeña cantidad de la planta expresada, que pongo a disposición del público, especialmente de los médicos, y he dado orden de coger por mi cuenta una cantidad considerable.

Suplico a V.E. dé al contenido de esta carta la mayor publicidad que se pueda, y tengo el honor de suscribirme de V.E. con sentimientos de alta estima y consideración, atento S.S. y Capellán". 
Cabe destacar que esta carta apareció tres días después en la prensa (La Gaceta, 6 de abril de1884, No. 79, p. 331), acompañada por una extensa carta de Castro Madriz, en la que expresaba que había comunicado lo pertinente al presidente Próspero Fernández Oreamuno, quien le expresaba su inmensa gratitud por tan importante iniciativa y su humanitarismo, así como el apoyo en lo que Thiel requería. Asimismo, es oportuno acotar que mes y medio después se reproducía en nuestra prensa una noticia intitulada Importante descubrimiento, publicada en el periódico mexicano El Siglo XIX (La Gaceta, 24 de junio de 1884, No. 142, p. 587); su redactor fue Andrés Clemente Vázquez, quien había residido en Costa Rica, donde conoció al obispo.

Se ignora si realmente las personas encargadas recolectaron los especímenes necesarios para que Liebreich efectuara los experimentos que ofreció; es posible que no, como es usual en nuestros países. Pero, además, Thiel alude a la toboba como si fuera una sola especie, y es posible que ese fuera un factor de confusión para los posibles recolectores; en realidad, él pareciera referirse a la terciopelo (Bothrops asper) (Figura 14).

Figura 14. Una terciopelo de 1,94 m de largo.

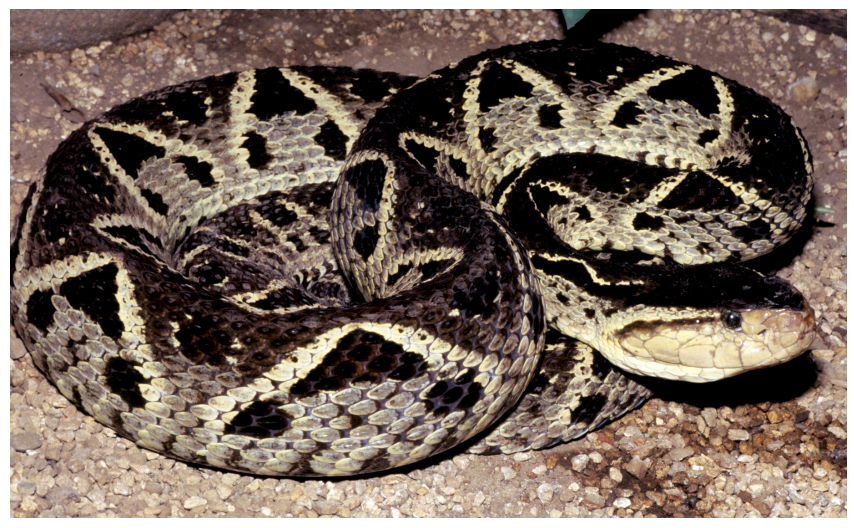

Foto: Alejandro Solórzano.

Cabe indicar que en el primer libro sobre nuestras serpientes, que data de 1931 (Picado, 1976), se consignan las siguientes especies para Costa Rica: cascabela, cascabela muda, mano de piedra, terciopelo, toboba chinga, tamagá, oropel, bocaracá, víbora de árbol, lora y corales. Nótese que apenas una tiene el calificativo de toboba, correspondiente a la toboba chinga (Bothrops lansbergii, hoy Porthidium lansbergii). Sin embargo, con excepción de las corales (familia 
Elapidae), a todas las demás se les denomina tobobas, pertenecientes a la familia Viperidae, caracterizadas porque tienen fosetas loreales -estructuras especializadas, entre el ojo y la boca, para percibir el calor de sus presas-, una cabeza con forma algo triangular, y escamas corporales de apariencia áspera.

En todo caso, como buen conocedor del carácter remolón del costarricense, y quizás previendo que no obtendría la ayuda deseada, Thiel hizo diligencias por su cuenta, como lo revela la siguiente carta, dirigida a Baltazar Quesada autoridad política en Grecia-, y transcrita por Herrera (2009):

\footnotetext{
"Los profesores de Europa me piden más de la planta que es el contraveneno contra la toboba. Hágame el favor de mandarme unas cinco libras, yo le arreglaré los gastos que ocasione la recolección. Lo mismo que piden dos tobobas conservadas en alcohol y ocho cabezas de toboba secadas al sol y colocadas en una lata de conservas con un poco de ácido carbólico y algodón. Creo que usted me puede ayudar para conseguir esto, con gusto pagaré todos los costos".
}

Es pertinente indicar que para entonces no había nacido el científico Clodomiro (Clorito) Picado Twight, pionero en el campo de los sueros antiofídicos; de hecho, cuando Thiel murió, Clorito era apenas un adolescente, que frisaba los 14 años. Sin embargo, muchos años después él efectuó experimentos con varias plantas y, enterado y motivado por las inquietudes del obispo, incluyó al citado helecho en sus pruebas, las cuales publicó en el ya citado libro (Picado, 1976).

Clorito evaluó por separado la acción inhibitoria de los extractos del tallo o el follaje del helecho sobre el veneno de la cascabel (Crotalus durissus), la cobra (Naja naja) y una coral extranjera (Micrurus fulvius), para lo cual utilizó palomas y cobayos como sujetos experimentales. Él concluyó que esta planta "es pues perfectamente útil para preservar de la intoxicación por veneno de cobra. Preserva también de las neurotoxinas termoestables de nuestras cascabelas, y además retarda la muerte por el veneno de coral". Al final, indica que -inyectado por vía intramuscular o intravenosa- el extracto "puede ser útil en los casos en que se haya aplicado una liga inmediatamente después de la mordedura", la cual evita la rápida difusión del veneno por el cuerpo y da tiempo para que el extracto actúe.

Por cierto, Clorito incluyó una fotografía de la planta en su libro (Figura 15), cuya leyenda dice: "Polypodium friedrichsthalianum. Helecho epífito cuyas hojas contienen un principio antagonista de las neurotoxinas ofídicas" (Picado, 1976). 
Figura 15. El helecho Polypodium friedrichsthalianum.

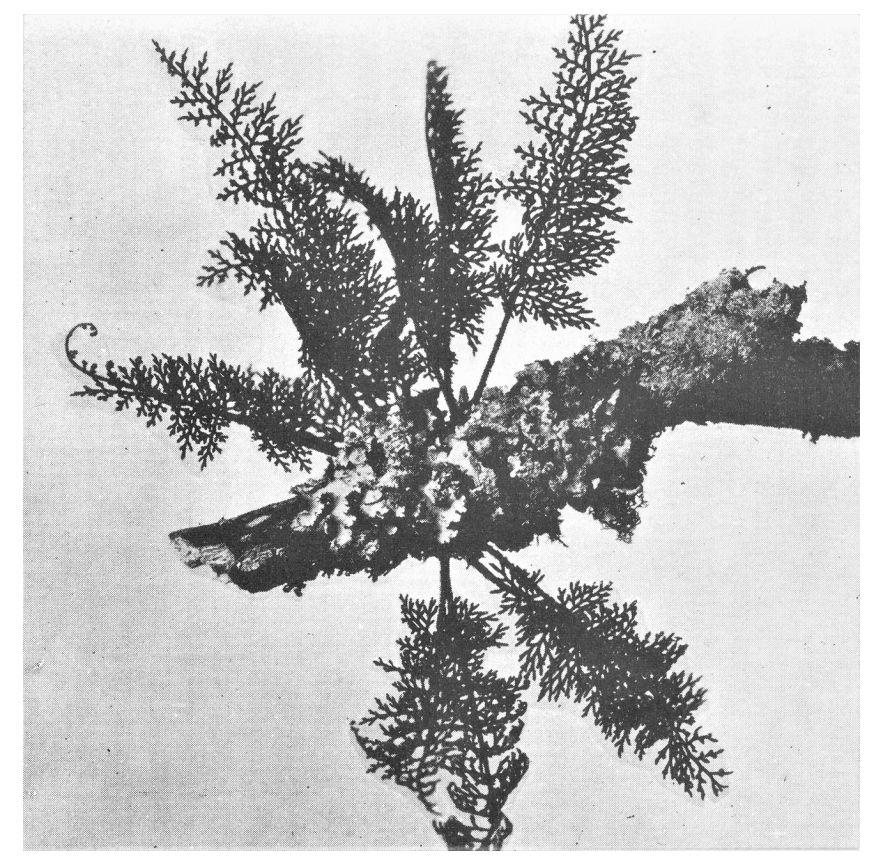

En síntesis, aunque los resultados no fueron totalmente concluyentes o contundentes, como ocurre con frecuencia durante la experimentación científica, es posible que Thiel se hubiera alegrado mucho de ver coronada su innovadora iniciativa, la primera en el país en este campo. Sin embargo, subsiste la duda de si el efecto de los extractos hubiera sido diferente en tobobas o en la terciopelo, que eran las especies que más le preocupaban a Thiel.

Conviene hacer una digresión para destacar que, como se vio en páginas previas, en una ocasión Thiel aludió a las semillas del cedrón (Simaba cedron) como contra-venenos. Al respecto, basado en los relatos y experiencias de otros países, Picado (1976) se propuso evaluar la veracidad de esa información. Fue así como, tras raspar la semilla para obtener su principio activo -un glucósido denominado cedrina- y diluirlo en alcohol, efectuó varios experimentos con veneno de cobra, que aportaron resultados confirmatorios, pero solo si la persona consume este antídoto antes de ser mordida, y no después; con otras especies, como la cascabel y la coral, los datos no fueron tan concluyentes.

Asimismo, en otra oportunidad Thiel consignó el dato de uno de sus colaboradores residente en Talamanca, quien señalaba que siempre tenía consigo una buena provisión de curarina, polvo reputado por salvar a los 
mordidos de serpiente. A diferencia del nombre cedrina -que corresponde al de una molécula o sustancia-, el término curarina no tiene ningún sustento químico, sino que quizás se deriva de curare, nombre que se refiere a una pasta elaborada a partir de una o más especies vegetales, con la que los indígenas suramericanos impregnan las puntas de sus flechas para capturar sus presas; es decir, al igual de manera análoga al término barbasco, no es el nombre de una especie en particular, sino de diversas plantas que comparten la capacidad de intoxicar peces, para así capturarlos fácilmente. Aunque Picado (1976) concluyó que la curarina, preparada por él a partir de varias especies de "patitos" (familia Aristolochiaceae), "nos mostró que no tiene ningún valor preventivo ni curativo sobre el envenenamiento ofídico", no puede descartarse que otras especies sí podrían tener efectos positivos.

Para concluir, de seguro Thiel hoy estaría muy feliz, al percatarse de que menos de un siglo después de su iniciativa, a partir de 1970 su amada Costa Rica ha destacado mundialmente en el campo de los sueros antiofídicos. Con ello ha sido posible salvar miles de vidas humanas -su mayor preocupación-, gracias a la extraordinaria labor del Instituto Clodomiro Picado, perteneciente a la Universidad de Costa Rica.

\section{Una nueva especie de ave}

Como se indicó páginas atrás, Thiel fue coleccionista de varios tipos de objetos. De hecho, en la apostilla aparecida en 1884 en el periódico mexicano El Siglo $X I X$, citada previamente, su autor Vázquez califica a su amigo Thiel como "un distinguidísimo naturalista alemán, que posee un notable museo zoológico y mineralógico, formado en varios países de Europa y la América del Sur". Esto parece un poco exagerado, pues lo que Thiel más recolectó fueron objetos de carácter arqueológico (Jones, 1916).

En cuanto a flora y fauna, no hay mención alguna de que contara con un herbario, aunque sí se anota la presencia de aves de Costa Rica y Ecuador, en este último caso con énfasis en colibríes (familia Trochilidae).

En el caso de insectos, tampoco hay referencias de que tuviera gabinetes con insectos debidamente preservados e identificados, aunque en la base de datos del AHABAT hay tres documentos que podrían inducir al error, y que ameritan un comentario. 
En efecto, fechada el 22 de enero de 1893, Thiel recibió desde Turín una carta del entomólogo Giacinto Gianelli, ofreciéndole intercambiar lepidópteros (mariposas) preservados e identificados, así como otros insectos (coleópteros, dípteros y hemípteros) preservados pero sin identificar. No obstante, al revisar con detenimiento la carta, escrita en inglés, se nota que era una especie de machote, en el que no aparece el nombre del destinatario, sino un impersonal "Estimado señor, ..." (AHABAT, I. 403, t. 1, f. 24).

Igual sucede con otra carta, también genérica, remitida el 30 de setiembre de ese mismo año desde Kingston por Charles Henry Tyler Townsend, curador del Instituto de Jamaica, en la que solicitaba el envío de insectos dañinos de cultivos agrícolas y de árboles, a la vez que especificaba cómo preparar los especímenes a enviar (I. 403, t. 1, f. 169). Aunque no pudimos hallar las respuestas de Thiel si es que las hubo-, es muy posible que les indicara que no conocía de insectos, o que remitiera las cartas a Biolley, entomólogo del Museo Nacional, aunque quizás éste también había recibido idénticas solicitudes.

En cuanto a la tercera carta, fechada en Nueva York el 6 de noviembre de 1888 y suscrita por un coleccionista apellidado De Satre (I. 378, t. 1, f. 303), éste deseaba comprar insectos al Dr. Julius Thiel -quien residía en Panamá, y cuyo nombre aparecía en un directorio de científicos en Boston-, por lo que le preguntaba los precios. En este caso, es claro que, por un inexplicable error en la oficina postal pertinente en EE.UU., la misiva fue enviada a monseñor Thiel, pero también sorprende que éste no la devolviera al remitente o la reenviara al entomólogo con el que compartía apellido.

Ahora bien, no hay duda de que a Thiel le interesaban las aves; tan es así, que en el AHABAT hay 11 cuentas de pagos efectuados durante 1900 al ornitólogo inglés Underwood, por sus labores en su colección de aves. Al parecer, le gustaban más las de colores hermosos, al igual que las de plumaje tornasolado, como los colibríes. Así lo sugiere o confirma un hecho muy curioso, que narramos a continuación.

Como se indicó en páginas previas, él tuvo la oportunidad de tratar muy de cerca a José Cástulo Zeledón (Figura 16A), pupilo de su coterráneo Alexander von Frantzius y después adiestrado como ornitólogo en el Instituto Smithsoniano, donde trabajó al lado del joven Robert Ridgway, que con los años se consolidaría como un reconocido taxónomo de aves tropicales. 
Cuando Zeledón murió, en 1923, su colega escribió un amplio obituario (Ridgway, 1923), en el cual enumeró todas las especies de aves recolectadas por su amigo que resultaron ser nuevas para la ciencia, de modo que él procedió a describirlas y bautizarlas.

Una de ellas era un mielero, pariente de la común viudita (Thraupis episcopus, familia Thraupidae), que en 1878 bautizó como Dacnis pulcherrima aureinucha, pero en una nota al pie consignó que no provenía de Costa Rica, sino de Ecuador, aunque remitida por Zeledón. En realidad, esta especie ya había sido descrita en 1853 por el inglés Philip L. Sclater, con base en especímenes provenientes de Colombia; es decir, lo que Ridgway describió fue una nueva subespecie. Una subespecie es una variante levemente diferente en su aspecto, que con el tiempo podría convertirse en una especie distinta, mediante el proceso de especiación, que es el surgimiento de nuevas especies de organismos a partir de un tronco o ancestro común.

Conocedores de la vida y la obra científica Zeledón, y de que él no había recolectado aves en dicho país (Hilje, 2013), este dato nos causó asombro. Y fue por ello que, en una oportunidad en que visitamos el Instituto Smithsoniano, tratamos de descifrar dicho enigma. En efecto, tras una larga búsqueda, ahí hallamos una tarjeta o boleta de registro del Museo de Historia Natural de los Estados Unidos, en la que constaba que la citada ave provenía de Ecuador -sin mencionar una localidad en particular-, y que había sido recolectada por $B$. Thiel; este nombre después fue tachado, y a la par se lee Bernardo Thiel.

Se ignora la manera exacta como Zeledón adquirió esa piel, pero es de suponer que él le comentó a Thiel que haría un envío de aves al Museo de Historia Natural, en el Instituto Smithsoniano, y entonces Thiel le entregó el espécimen embalsamado de esa especie, para que Ridgway le comunicara a cuál especie pertenecía. La gran sorpresa fue que... jresultó ser una subespecie nueva para la ciencia! En todo caso, sin proponérselo, gracias a Thiel una nueva subespecie se sumó a la lista de la avifauna de Ecuador. Es oportuno indicar que después fue rebautizada como Tangara pulcherrrima y posteriormente como Iridophanes pulcherrimus, de modo que la subespecie remitida por Thiel hoy se denomina Iridophanes pulcherrimus aureinucha. 
Figura 16. El ornitólogo Zeledón (A) y un macho del mielerito collarejo (B).

A.

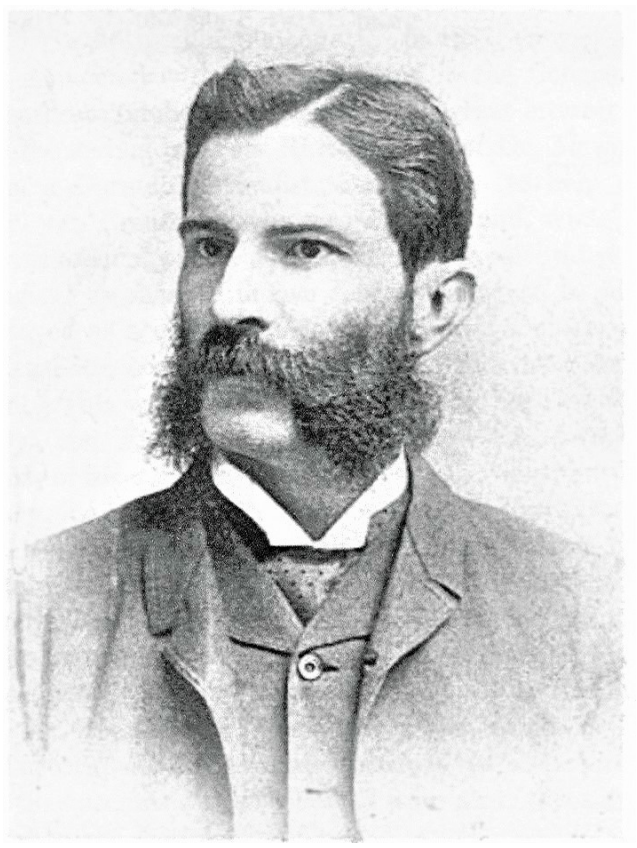

B.

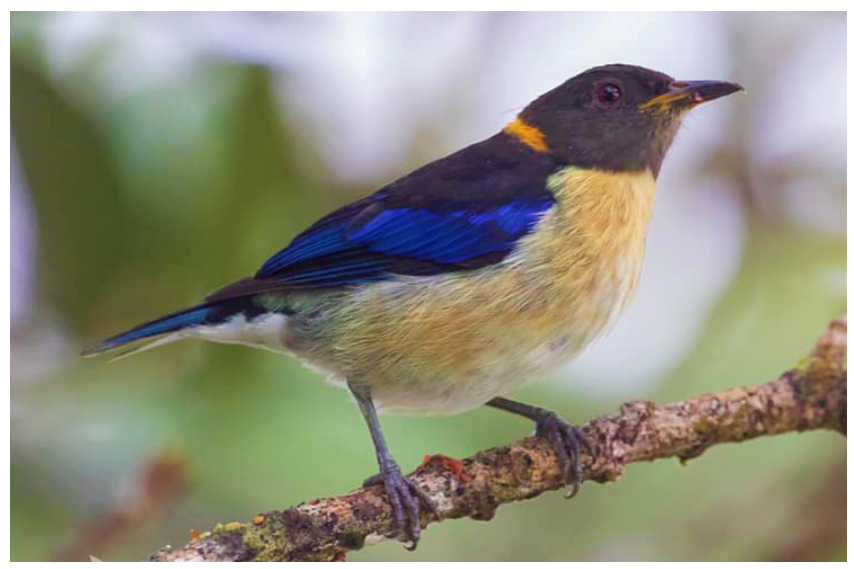

Foto: Mauro Ossa.

Cabe acotar que, según el ornitólogo Gary Stiles, quien reside en Colombia, esta bella ave, de cabeza negra y vientre crema, alas negras y azuladas y una franja amarilla en la parte superior del cuello (Figura 16B), a la que se le llama mielerito collarejo, se distribuye desde la parte sur de la costa del Pacífico en Colombia, y más al sur hacia el norte de Ecuador; ya en el suroeste de Colombia y el este de Ecuador es reemplazada por una subespecie denominada Iridophanes pulcherrimus pulcherrimus, que tiene el "collar" amarillo menos evidente. 
Según dicho especialista, no es un ave fácil de observar, pues casi siempre anda en el dosel o estrato superior del bosque. Puesto que la única manera de recolectarla era disparándole, y con muy buena puntería, pues es un ave pequeña, y quizás Thiel no la tenía, a juzgar porque en su país se le eximió del servicio militar al ordenarse sacerdote, según la legislación alemana de la época (Sanabria, 1941). Estos hechos permiten suponer que no fue él quien recolectó esta ave, sino que alguien más lo hizo y después se la obsequiaron.

\section{Thiel y la deforestación}

En las crónicas de Thiel hay menciones de dos especies arbóreas, pero no por su valor económico, sino por sus dimensiones, en un contexto silvestre. En el primer caso, anota que "el curso del Río Frío es muy sinuoso y cambia de perspectiva a cada vuelta. [...] Aquí un tronco que sobresale de las aguas nos obliga a rodearlo y allá un espabel atravesado nos pone en peligro de naufragar"; el espavel (Anacardium excelsum), es frecuente en las riberas de ríos. En el segundo caso, en Talamanca, consigna que

\footnotetext{
"fue imposible pasar el río, sus caudalosas aguas no dieron paso. [...] En un sitio en donde el río se divide en dos brazos se descubrió un árbol de sotacaballo de grandes proporciones. Este nos sirvió para hacer un puente pasando palos grandes de 10 varas desde la corona al otro lado del río, en donde en una peña que estaba en el río algo apartado de la orilla, pero todavía en el agua hicimos descansar los palos que debían servir de escalera para bajar desde la corona del sotacaballo. En la noche quedó el puente hecho y amarrado con bejucos".
}

Dicha especie (Zygia longifolia) se caracteriza por poseer una copa muy ramificada, y es común en las orillas de ríos.

Ahora bien, Thiel también se refirió a la exportación de maderas preciosas, y con preocupación. Así ocurrió durante una estadía en Santa Cruz, Guanacaste, a inicios de 1884, de paso por el caserío de Tempate. En su relato dice así:

"Este barrio tiene ochenta casas, con 380 a 400 habitantes, la mayor parte de las personas parecen bien acomodadas, debido sin duda al negocio de madera que se hace en grande escala. De las montañas de este barrio se habrán reportado hasta 15 mil trozas de caoba y cedro, el precio mínimo de una troza es de 4 pesos. Debido a este movimiento comercial, han venido personas de otras partes a vivir aquí temporalmente. Por todas partes se ven patios de madera -así les Ilaman- con 150 a 300 trozas, ya listas para ser llevadas a la costa. Se han hecho en el distrito de Santa Cruz 3 o 4 caminos carreteros, por donde se lleva la madera a la playa. El principal embarcadero es El Portillo, pero hay otros puntos en donde anclan los buques de vela para cargar. Es de sentir que este negocio no es duradero, pues en 4 o 5 años tiene de acabarse su fácil exportación". 
Más adelante señalaría que "el acopio de maderas en la costa es muy grande".

Además, en otro párrafo de su crónica narraría que "ya oscureciéndose, llegamos a la isla de Chira, célebre en la antigüedad por su mucha población india, hoy desierta. Estaban cargando en la punta tres buques: madera de cedro, resto de su antigua riqueza". Esto revela que en esa grande y bella isla del golfo de Nicoya en aquel momento ya casi no quedaban árboles de cedro.

Igualmente, en una carta dirigida dos años antes al cura español José María Velasco, quien tenía bajo su tutela la llamada cofradía de la hacienda de Jesús, se le indicaba lo siguiente:

\begin{abstract}
"Su Señoría llustrísima estaba en la opinión de haberle enviado a usted el poder necesario para proceder judicial y extrajudicialmente en el negocio de las maderas que cortó Alfonso Salazar. Lo primero que hay que hacer naturalmente, como le indiqué anteriormente, es el nombramiento de peritos de ambos lados para que valúen la madera cortada y labrada. Si se deben apreciar las maderas por toneladas o matas, si hay que tener en cuenta la diferencia entre el brasil y la mora, esto lo sabrá usted mejor que nosotros en el interior en donde carecemos de los conocimientos prácticos para decidir con acierto tal cuestión. Usted no tiene que mirar otra cosa que los mayores intereses de la iglesia de Nicoya y atenerse al dictamen de los peritos".
\end{abstract}

Asimismo, en Herrera (2009) aparece una interesante carta, que data de casi medio siglo antes. En efecto, el 15 de abril de 1849, Manuel Aguilar, presidente municipal de Nicoya, le advertía al mayordomo de la citada cofradía de Jesús

\footnotetext{
"que tenga especial cuidado en que sin su consentimiento [...] corten maderas útiles, a no ser por medio de una contrata especial que usted celebre con el que la solicite, a excepción de las maderas de brasil, que para hacerlo deberá ser con aprobación de este cuerpo, y el que sin los requisitos expuestos cortase maderas, lo acusará ante la autoridad para que se le castigue el avance y pague los perjuicios que haya irrogado, haciéndole a usted responsable a todo lo que por su negligencia, tolerancia o descuido, deje de cobrarse".
}

Al respecto, en los relatos de viajeros del siglo XIX eran casi infaltables las menciones de las cuatro especies de árboles recién citadas: la caoba (Swietenia macrophylla), el cedro amargo (Cedrela odorata), el brasil (Haematoxylon brasiletto) y el mora (Maclura tinctoria), las cuales se exportaban masivamente desde Guanacaste (Hilje, 2013, 2015). Su gran demanda en los mercados internacionales obedecía a la extraordinaria calidad de su madera, útil para construcción, ebanistería y fabricación de instrumentos musicales finos; además, las dos últimas eran una fuente muy importante de tintes de muy alta calidad. 
Según se verá pronto, en un escrito de Thiel alusivo a la celebración de la "Fiesta de los Árboles", en 1901 expresaría su preocupación por lo atestiguado en Guanacaste con estas especies maderables y tintóreas. Como bien lo advirtiera él, la sobreexplotación de estas especies, así como la ausencia de proyectos de reforestación -algo inimaginable en aquellos tiempos-, con el tiempo provocaría tal escasez, que hoy es difícil conseguir caoba, brasil y mora, mientras que las poblaciones de cedro aprovechable son mínimas.

Ahora bien, es pertinente indicar que aunque en los relatos de Thiel al cedro se le menciona 12 veces, casi siempre es en el contexto de su utilización en construcción o ebanistería, por ejemplo para cubrir el cielorraso o el piso de una iglesia, o para hacer un armario, debido a la alta calidad de su madera. En un caso muy diferente, cuando trataba de seleccionar un predio para establecer una ermita en Upala, él narra que en un punto de la margen derecha del Río Frío, "labré una cruz grande en un cedro macho y encargué a Juan Alvarez que me desmontara unas tres manzanas para una plaza, iglesia y principio de población". Según Herrera (2009), este punto fue el núcleo para la conformación del actual San Rafael de Guatuso, lo cual significa que aquel árbol de cedro macho o caobilla (Carapa guianensis) marcado por Thiel fue el hito fundacional de este poblado.

En cuanto a otras especies de árboles maderables de muy alta calidad, que son muchas en Costa Rica, hay apenas tres menciones en las crónicas de Thiel. A pesar de su valor, no aparecen especies como el almendro (Dipteryx panamensis), el cativo (Prioria copaifera), el cocobolo (Dalbergia retusa), el cristóbal (Platymiscium pinnatum), el danto amarillo o tempisque (Sideroxylon capiri), el manú (Minquartia guianensis), el nazareno (Peltogyne purpurea), el ñambar (Platymiscium parviflorum), el olla de mono (Lecythis ampla) ni el ronrón (Astronium graveolens) (Jiménez et al., 2002).

De las tres especies citadas, en un relato sobre San Marcos de Tarrazú se indica que "las gradas para subir al presbiterio deben hacerse de piedra viva o de tablones fuertes de roble", es decir, quizás el encino (Quercus bumelioides) o también $Q$. corrugata y $Q$. salicifolia, según el botánico Jiménez. Por su parte, de Talamanca, Thiel indica que "hay mucho laurel y extensos platanares a la orilla del río Sirole [Shiroles]"; el laurel (Cordia alliodora) crece con gran vigor en esa zona. La tercera mención corresponde al modo en que los indios bribris conservan los huesos de los difuntos, protegidos con tablones de palo santo. 
En este último caso, Thiel agrega que "el árbol de palo santo es una clase de caoba. Se ha encontrado hasta ahora solo en las montañas de Lari. Su madera es muy dura. Los antiguos indios hacían de él instrumentos de música. Los actuales indios conservan algunos de estos instrumentos, que bien pueden tener dos $y$ tres siglos". Al respecto, Pittier (1938) acota que los cementerios "consisten en una especie de casa construida de la madera de un árbol llamado tsurit o palo santo"; según Alí García Segura, se trata de tapescos o estantes elaborados con tablas de palo santo, cuyo nombre no es tsurit sino tsulë'. En realidad, el palo santo o guayacán real (Guaiacum sanctum), hoy casi extinto, no es pariente de la caoba, pero su madera es de extraordinaria calidad. Sin embargo, según el botánico Jiménez, su distribución en Costa Rica se restringe a Guanacaste, por lo que la especie utilizada por los bribris podría ser más bien del manú, manú negro o palo de piedra (Minquartia guianensis), sumamente dura; esto fue confirmado por Alí García y su hermano Bajil Segura, quien es ebanista en Suretka.

A propósito de la extinción o pérdida de especies por su sobreexplotación, a inicios de 1901 y sin proponérselo, Thiel tuvo la oportunidad de manifestar por escrito su preocupación por la deforestación que ya empezaba a observarse en Costa Rica, y sus consecuencias. En efecto, invitado a colaborar en la Fiesta de los Árboles -equivalente al actual Día del Árbol-, organizada por la Municipalidad de San José, así lo hizo en una carta remitida al comité organizador del evento.

Éste estaba integrado por el intelectual Miguel Obregón Lizano, inspector general de Enseñanza, el militar y periodista colombiano Francisco Serrano Leyton, por entonces inspector de Hacienda Municipal, y el regidor municipal Ciriaco Zamora Villalta; curiosamente, en dicho comité no había ningún naturalista.

Cabe acotar que la iniciativa de la celebración, surgida a en febrero de 1901, provino del regidor Zamora (Boletín Municipal, 1-III-1901, p. 4). En dicha publicación, más adelante se indicaba lo siguiente:

"Día de los árboles. Ha sido instituida para el Cantón de San José esta fiesta civilizadora, que se celebrará por primera vez en Costa Rica el $1^{\circ}$ de mayo próximo. De desearse sería que siguieran el ejemplo los demás cantones de la República, y aún todavía mejor que el próximo Congreso Constitucional legislara sobre el particular. Piénsese bien en el beneficio que de ello reportarán las generaciones por venir". 
Sin embargo, hubo un contratiempo, pues había una fuerte sequía, lo que obligó a trasladar la festividad para el día 15 de mayo, día de San Isidro Labrador (La República, 28-IV-1901, p. 3).

Para retornar a la carta de Thiel, fechada en San José el 4 de mayo de 1901, había permanecido inédita hasta que fue reproducida y publicada en la prensa (Diario de Costa Rica, 12-X-1923, p. 3), a raíz de la inauguración de su estatua, erigida en los jardines de la Catedral Metropolitana. De hecho, con el título Un artículo inédito de Monseñor Thiel, en días previos había aparecido en dicho medio la noticia del hallazgo de este documento (Diario de Costa Rica, 15-IX1923, p. 2), y se anunciaba que sería publicado pronto, como en realidad se hizo. En su carta, Thiel expresaba lo siguiente.

\section{Muy señores míos:}

Durante mi último viaje a la provincia de Guanacaste, recibí su atenta carta del 15 de abril pasado, contraída a convidarme a que colabore con U.U. en la solemnidad de la "Fiesta de los Árboles".

Veo que U.U. quieren imitar en Costa Rica la idea iniciada en Italia por el Ministro de Instrucción Pública, del Doctor [Guido] Baccelli, y acogida con entusiasmo en algunas repúblicas sudamericanas; y que al efecto se ha formado aquí un Comité organizador de la fiesta en el cual U.U. figuran como miembros.

Con gusto correspondo a su invitación de colaborar en cuanto me corresponda a la realización de su proyectada fiesta.

El proyecto de despertar en nuestra juventud de ambos sexos, tanto de enseñanza primaria como secundaria, el amor por la naturaleza exterior, y con preferencia a los árboles, por medio de exposiciones teóricas claras y sucintas y la práctica de la siembra de árboles, rodeada de todo el aparato de una solemnidad exterior que conmueva los ánimos juveniles y les deje impresiones favorables y permanentes para toda la vida, es digno de toda alabanza, por la utilidad que ha de producir en el porvenir a la patria.

Durante muchos años, especuladores sin escrúpulos, sin previsión de los daños que hacían, y sin sentimientos estéticos, atraídos únicamente por el lucro del momento, se ocupaban en Italia en cortar todos cuantos árboles podían comprar, ya en los bosques, ya en los caminos públicos, en las orillas de los ríos y en las propiedades privadas. Su proceder hubiera sido funestísimo para el país, si el gobierno, justamente alarmado, no hubiera puesto término a sus devastaciones y ordenado una nueva siembra general de árboles en todo el Reino. 
Revista Herencia, Vol. 33 (2), julio-diciembre, 2020.

El Doctor Baccelli, uno de los médicos más célebres de Italia, entonces Ministro de Instrucción Pública, fue el principal promotor de la medida gubernativa. Él no solo demostró que los árboles son muy útiles y de gran ornato, que dan sombra y alegran la vista, que impiden el lavamiento y empobrecimiento de los terrenos altos, que favorecen y regularizan el descenso de las lluvias, sino que quiso también que el recuerdo de la replantación de árboles en Italia fuese celebrado por medio de una solemnidad, en la cual debían tomar parte todas las escuelas primarias y secundarias, los profesores, inspectores, y hasta el Ministro debía realizar una solemnidad en favor de los árboles y arbustos con su presencia.

En 1900 asistieron el rey y la reina en persona a la fiesta de los árboles. El Ministro o alguna persona designada por él pronuncia un discurso, sigue la siembra de árboles por los alumnos de ambos sexos, con un entusiasmo admirable. Durante la plantación se canta un himno a los árboles, sigue un ligero refresco con brindis diversos, y por fin desfilan niños y niñas delante del Ministro y demás autoridades.

En Roma fue escogido el vasto terreno de la Farnesina, situado cerca de Ponte Molle, para la siembra de los árboles y ya sueñan los habitantes de Roma en las alegres tardes que han de pasar más tarde a la sombra de los árboles sembrados por manos juveniles, saboreando los vinos de los Castelli romani.

En Costa Rica la destrucción de los árboles está muy lejos de sentirse de la misma manera como en Italia. Tenemos todavía bosques inmensos seculares, y aún en el interior, en donde prevalecen las plantaciones de café, y la siembra de ese arbusto de regular tamaño, es favorable a la de los árboles protectores; sin embargo, sentimos aquí la desaparición de ciertos árboles utilísimos en construcción, como el cedro, la caoba y otros. Los centenares de miles de cedros y caobas que existían al principio del siglo XIX en el interior, en las provincias de San José, Heredia, Alajuela y Cartago, han sido cortados, sin sembrar un solo árbol. Esto es triste, y ahora lo sentimos viéndonos en la necesidad de traer las maderas de construcción de los lugares más remotos accesibles, en donde también disminuyen cada día más. En la provincia de Guanacaste se han explotado igualmente las maderas útiles: el cedro, la caoba, el brasil, en los últimos veinte años en tal escala, sin pensar en la resiembra, que estos árboles se deben llamar ya raros y escasos en la provincia.

El peligro de la desaparición de los árboles valiosos y útiles nos amenaza, luego, necesario es que se despierte el interés y entusiasmo por la replantación de ellos.

El constante aumento de la población exige que cada año se dedique un área mayor a la agricultura y pastos de animales, luego han de disminuirse paulatinamente los bosques. Sin embargo, como éstos desempeñan un papel importante en la climatología del país, la misma legislación que ahora prohíbe el corte de los árboles en las orillas de los ríos y quebradas debería también reglamentar el desmonte de los bosques, eximiendo, por ejemplo, las zonas altas y cumbres de las montañas, y ordenando, en los puntos en donde el hombre por inconsideración ha ido demasiado lejos en los desmontes, la resiembra de cedros, caobas y otros árboles útiles. 
La "Fiesta de los Árboles" iniciada por U.U. despertando el entusiasmo en la juventud e ilustrando con discursos prácticos y adecuados las masas populares sobre el papel importante que tienen en la naturaleza los árboles, preparará el terreno para que las disposiciones legislativas que en tal sentido fueren dadas, sean recibidas con aplauso por los pueblos, y respetadas y ejecutadas con buena voluntad.

Bajo estos puntos de vista aplaudo la fiesta nueva proyectada y deseo U.U. alcancen un éxito feliz.

El peligro que asoma en esta clase de empresas, como se ha notado en Italia y otras partes, consiste en que ciertos elementos de la sociedad que carecen de fundamentos religiosos sólidos, aprovechen estas ocasiones para hacer propaganda para sus falsas ideas naturalistas y positivistas que rechaza el pueblo cristiano. En varios discursos pronunciados en tales fiestas en otras partes, se nota una tendencia a encomiar cierto neo-paganismo moderno, ideal de algunos ilusos. Con tales tendencias malsanas se hacen sospechosas y se destruyen medidas en sí utilísimas.

Espero que en Costa Rica se sabrá evitar estos escollos.

Siento que mis ocupaciones no me permitan tomar personalmente parte en la "Fiesta de los Árboles", que como he visto, ha sido transferida al 15 de este mes, pero la acompaño con mis simpatías más vivas".

De U.U. Atto. Servidor y Capellán,

Bernardo Augusto, Obispo de Costa Rica

Al margen de su tono confrontativo con los liberales promotores del positivismo aludido en uno de sus pasajes, esta carta es muy significativa en términos históricos, pues su contenido posiblemente sea pionero en América Latina en cuanto al llamado de la Iglesia católica a la conservación de los bosques y del ambiente en general.

Es de suponer que las opiniones de Thiel estuvieron influenciadas -al menos de manera indirecta- por las de su amigo Pittier, quien ya en 1891 había sido el primer individuo que, con sólidas bases científicas, había advertido acerca de la deforestación en Costa Rica y sus riesgos (Hilje, 2015). Asimismo, es posible que también tuvieran el influjo del botánico y jardinero sueco Alfredo Anderson Sandberg, quien había arribado a Costa Rica en 1894. Tanto se interesó Anderson por la reforestación del país, que en una ocasión expresó lo siguiente por la prensa:

"La mayoría de los costarricenses aún no comprende la urgencia de resembrar los árboles que se cortan y la previsión de conservar una zona inviolable de reserva forestal, con el fin de garantizar, para el futuro, la abundancia de aguas, para los diferentes usos de la vida moderna, con sus múltiples exigencias sociales" (La Tribuna, 20-IV-29). 
Y a esto agregaba que: "Mi campaña en Costa Rica por la conservación y la repoblación de los bosques data ya de más de 30 años y, si en esta larga lucha no se han agotado las fuerzas, es porque nunca he perdido la fe en el resultado final de mis empeños".

En cuanto a la Fiesta de los Árboles, una gran multitud se congregó en el Parque Central a las siete de la mañana del miércoles 15 de mayo, desde donde una hora después, precedidos por la banda del ejército, los estudiantes de primaria y secundaria de la capital avanzaron hasta La Sabana, para sembrar los arbolitos, en "el futuro Parque Chapui" (El Heraldo de Costa Rica, 16-V-1901, p. 2; La República, 16-V-1901, p. 1-2). A éste se le denominaría así en honor a Manuel Antonio Chapuí Torres, sacerdote y gran benefactor, quien había donado ese y otros vastos terrenos a los vecinos de la capital. Según el programa, entre los dignatarios que encabezaban el séquito figuraba el obispo diocesano ( $L a$ Gaceta, 4-V-1901, p. 411) (Figura 17), es decir, Thiel, pero se ignora si se apersonó o envió a un representante, pues ninguno de los periódicos revisados menciona su presencia.

Figura 17. Fragmento del programa de la Fiesta de los Árboles, en el que se menciona la participación de Thiel como obispo diocesano.

\section{FIESTA DE LOS ARBOLES}

para el 15 de mayo de 1901, á las 7 a. $m$.

\section{Programa}

$$
\text { 1. Parte }
$$

I. A las 7 de la mañana se congregará la concurrencia al derredor del Parque Central, donde será organizado el cortejo.

II. Partirá la procesión cívica, en dirección á la Sabana de Mata Redonda, precedida por la banda marcial y la fuerza pública, en el siguiente

\section{Orden de formación:}

I? - El señor Presidente de la República, el Presidente de la Cámara de Diputados, el Presidente de la Corte Suprema de Justicia, los Ministros de Estado, el Cuerpo Diplomático y S. S. I. y R., señor Obispo diocesano.

2:-El Supremo Poder Legislativo.

3:-El Supremo Poder Judicial.

$4^{\circ}$ - El Cuerpo Consular. 
Ya en el sitio, ante una concurrencia calculada por la prensa en unas seis mil personas, se entonó el himno nacional y hubo un discurso de Ricardo Pacheco Marchena, ministro de Gobernación -en representación del presidente Rafael Iglesias Castro-, tras lo cual los niños cantaron el Himno de la Fiesta del Árbol, escrito y musicalizado para la ocasión por el educador Napoleón Quesada Salazar y el artista Pedro Calderón Navarro, respectivamente.

De inmediato, con gran solvencia retórica intervino el intelectual cubano Antonio Zambrana Vázquez, y después declamó un poema inédito el eximio escritor peruano José Santos Chocano Gastañodi, quien había llegado al país tres semanas antes en funciones diplomáticas; como una curiosidad, años después él escribiría la letra del actual Himno al Árbol que, musicalizado por el costarricense Roberto Campabadal Gorró, se estrenó el sábado 10 de noviembre de 1923 en el Templo de la Música, en el Parque Morazán, cantado por los niños de cuatro escuelas capitalinas (Diario de Costa Rica, 11-XI-1923, p. 6, La Tribuna, 11-XI-1923, p. 7).

Terminadas las alocuciones, la celebración culminó con un refrigerio, mientras los estudiantes sembraban los arbolitos en dicho predio, en un espacio previamente delimitado y en puntos específicos marcados con banderitas.

Ahora bien, sí llama la atención que, quizás por razones protocolarias, ese día la carta de Thiel fuera ignorada en las alocuciones, a pesar de su importante mensaje conservacionista. Aunque días después se anunció que se publicaría un folleto "con los discursos y poesías que en esa ocasión se dijeron" (El Heraldo de Costa Rica, 19-V-1901, p. 3), a pesar de grandes esfuerzos de búsqueda, no nos fue posible localizarlo, lo cual sugiere que nunca se editó; sin embargo, por fortuna uno de los diarios publicó íntegra la alocución de Zambrana (El País, 17V-1901, p. 1), en tanto que otro hizo lo propio con el poema de Chocano (El Progreso, 28-V-1901, p. 3). En cuanto a la carta de Thiel, es de suponer que el regidor Zamora la conservó en sus archivos, y que fue quien la hizo llegar al Diario de Costa Rica, periódico en el cual él colaboraba; de hecho, durante setiembre de 1923 publicó un extenso artículo intitulado Talamos, no sembramos, en tres entregas (Diario de Costa Rica, 11-IX-1923, p. 2; 14-IX-1923, p. 7; 19-IX-1923, p. 3). 
Cabe mencionar que, sin proponérselo él, dicha carta representó una especie de despedida de parte de Thiel. En efecto, pocos días después de que la escribió, se enrumbó hacia San Ramón, Puntarenas y Guanacaste, y "entre Bagaces y Liberia lo atacó el asma de verano, malestar que aumentó a su regreso a San José" (Herrera, 2009), después de lo cual se agravó su situación. De hecho, moriría el 9 de setiembre, exactamente cuatro meses después de escrita la carta.

Por una feliz coincidencia -o quizás no lo fue tanto, como se indicó previamente-, la carta de Thiel fue publicada en la prensa apenas un mes antes de este acto. Sin embargo, pareciera que no recibió la atención que su contenido ameritaba.

\section{Epílogo}

Muchos años después de fallecido Thiel, cuando el insigne biólogo Clorito Picado analizó las propiedades antiofídicas del helecho recolectado por éste, sorprendido por la versatilidad de Thiel, en forma jocosa a la vez que respetuosa consignó que "fue, además, obispo de Costa Rica", frase que él atribuye al ya citado Zambrana, quien dejara una indeleble huella en nuestro país. De manera implícita, Picado sugiere que, infatigable como era, fueron tantos los asuntos de que se ocupó Thiel durante su vida, que apenas si le quedaba tiempo para dedicarlo a las labores inherentes al arzobispado. En efecto, en un antiguo y breve artículo reproducido en la prensa cuando se inauguró la estatua de Thiel (Diario de Costa Rica, 12-X-1923, p. 3), Zambrana destaca el brillo intelectual de Thiel, así como sus amplios y profundos conocimientos filosóficos, para culminar expresando que: "el positivismo, el materialismo, el ateísmo, no le asustaban; discutía con ellos tranquilamente. Su ciencia era ancha y su inteligencia más ancha todavía. Tal me pareció siempre el Doctor Thiel, que además era Obispo".

Por fortuna, como parte de tal amplitud de intereses, Thiel no ignoró la relación del hombre con el mundo natural pero, ¿fue él un naturalista? A nuestro criterio no, pues aunque realizó contribuciones valiosas en el campo de las ciencias naturales, éstas no fueron abundantes ni profundas, por ejemplo en botánica, zoología, geología, mineralogía o vulcanología, disciplinas en las que los auténticos naturalistas de entonces -que representan una estirpe casi extinta hoy- hicieron notables aportes, sobre todo en los siglos XVIII y XIX. En el plano mundial, son ejemplos cimeros el alemán Alexander von Humboldt y el inglés 
Charles Darwin, mientras que en Costa Rica, por sus amplias recolecciones o escritos pioneros, sobresalieron Anders S. Oersted, Karl Hoffmann, Alexander von Frantzius, Julián Carmiol, Auguste R. Endrés, Helmuth Polakowsky, Henri Pittier, Paul Biolley, Adolphe Tonduz, Carlos Wercklé, Karl von Seebach, Karl T. Sapper, George K. Cherrie y Cecil Underwood, más los nacionales José Cástulo Zeledón, Anastasio Alfaro y José Fidel Tristán.

En tal sentido, a Thiel se le puede considerar más bien como un naturalista aficionado, al igual que lo fueron otros individuos -tanto extranjeros como nacionales- que en aquellas épocas se dedicaron primariamente a otras actividades, pero siempre mantuvieron un interés explícito por entender y valorar lo que el mundo natural representa para el ser humano en términos económicos y sociales, así como estéticos, éticos y hasta espirituales.

\section{Agradecimientos}

Dedico este artículo a la memoria de don Luis Pérez Loaiza, mi suegro, ávido lector e incansable contertulio, a quien pude llevar en mi automóvil a recorrer parte de la ruta de exilio de monseñor Thiel, cuya obra admiraba y conocía muy bien. De seguro que hubiera disfrutado mucho la lectura de este artículo.

Agradezco el aporte de valiosa información a Pablo Durand Baquerizo y Nicole Marín Muñoz (AHABAT), Ana Isabel Herrera Sotillo, Quírico Jiménez Madrigal, Luis Sandoval Vargas, Alejandro Solórzano López, María Eugenia Bozzoli Vargas, Alí García Segura, Bajil Segura Segura, Fernando González Vásquez, Rafael Ángel Ocampo Sánchez, Frank Garfield (Gary) Stiles, Mario Monteforte Sánchez, Mario Saborío Mora, Paul Hanson, Emilio Obando Cairol ( $\dagger$ ) y Jafeth Campos Soto. Asimismo, a quienes me facilitaron las figuras que ilustran este artículo: Miguel Ángel Quesada Pacheco (1 y 7), Ligia Carmiol Fernández (2B), Marlin Calvo Gamboa (Museo Nacional) (4A), Alvaro Castro Harrigan (8), Eduardo Carrillo Jiménez (10), Myrna López Sánchez (11A), Alejandro Solórzano (12A-B y 14), Guillermo Saborío Vega (13) y Mauricio Ossa (16B). A Silvia Kruse Quirós, la traducción de varios documentos en alemán. $A$ Theresa White, la revisión de la versión del resumen en inglés. 


\section{Bibliografía}

Alfaro, A. (1930). Don Pedro Porras Bolandi. Repertorio Americano. Tomo XX. No. 13. 29-III-1930. p. 199-201.

Anónimo, (1893). Catálogo general de la Exposición Histórico-Americana de Madrid, 1892. Tomo 1. Madrid: Establecimiento Tipográfico Sucesores de Rivadeneyra, $327 \mathrm{p}$.

Benzoni, G. (1565). La historia del Mundo Nuovo. Venecia: Apresso Francesco Rampazetto. 175 p.

Blanco, R. (1984). 1884, el Estado, la Iglesia y las reformas liberales. San José: Editorial Costa Rica. 374 p.

Bovallius, C. (1887). Viajes por Centroamérica (1881-1883). Serie Viajeros No. 1. Managua: Banco de América. 316 p.

Bussing, W. A. (1987). Peces de las aguas continentales de Costa Rica. San José: Editorial de la Universidad de Costa Rica. 271 p.

Carrillo, E., Wong, G. \& Sáenz, J. C. (1999). Mamíferos de Costa Rica. Heredia: Editorial Instituto Nacional de Biodiversidad (INBio). 248 p.

Conejo, A. (1975). Henri Pittier. Serie ¿Quién fue y qué hizo? No. 20. San José: Ministerio de Cultura, Juventud y Deportes. 162 p.

Díaz, R. (2007). La ciencia y el debate entre la Iglesia Católica y el liberalismo en Costa Rica (1880-1901). Diálogos (Revista Electrónica de Historia) 7(2): 1-18.

Ferrero, L. (1978). Talamanca, el espacio y los hombres. Serie Nos Ven No. 7. San José: Ministerio de Cultura, Juventud y Deportes. 198 p.

Garrón de Doryan, V. (1974). Anastasio Alfaro. Serie ¿Quién fue y qué hizo? No. 17. San José: Ministerio de Cultura, Juventud y Deportes. 189 p.

Herrera, A. I. (2009). Monseñor Thiel en Costa Rica: visitas pastorales 1880-1901. Cartago: Editorial Tecnológica de Costa Rica. 859 p. 
Hilje, L. (2015). Don Juan Rafael Mora y las ciencias naturales en Costa Rica. Alajuela: Editorial Universidad Técnica Nacional (EUTN). 127 p.

Hilje, L. (2014). Un Museo Nacional para Costa Rica, a mediados del siglo XIX. Revista Comunicación 23(2). 60-71.

Hilje, L. (2013). Trópico agreste; la huella de los naturalistas alemanes en la Costa Rica del siglo XIX. Cartago: Editorial Tecnológica de Costa Rica. 868 p.

Hilje, L. (2008). Don Alfredo Anderson y La Sabana. Diario digital Tribuna Democrática. 21 de agosto de 2008.

Hilje, L. (2006). Karl Hoffmann: naturalista, médico y héroe nacional. Heredia: Instituto Nacional de Biodiversidad (INBio). 200 p.

Jiménez, Q., Rojas, F., Rojas, V. \& Rodríguez, L. (2002). Árboles maderables de Costa Rica. Ecología y silvicultura. Heredia: Editorial Instituto Nacional de Biodiversidad (INBio). 370 p.

Jones, J.B. (ed.). (1916). El "Libro azul" de Costa Rica. The Latin American Publicity Bureau. 538 p.

León, J. (1987). Botánica de los cultivos tropicales. San José: Instituto Interamericano de Cooperación para la Agricultura (IICA). 445 p.

León, J. \& Poveda, L. J. (2000). Los nombres comunes de las plantas en Costa Rica. San José: Editorial Guayacán. 870 p.

Martínez, B. (2016). Himnos de mi patria, cantos de mi país. San José: Editorial Imprenta Nacional. 64 p.

Picado, C. (1976). Serpientes venenosas de Costa Rica; sus venenos y seroterapia anti-ofídica. 2 ed. San José: Editorial de la Universidad de Costa Rica y Editorial Costa Rica. 241 p.

Pittier, H. (1938). Apuntaciones etnológicas sobre los indios bribri. Serie Etnológica, vol.1, parte 1. San José: Museo Nacional de Costa Rica. 28 p. 
Pittier, H. (1908). Plantas usuales de Costa Rica. Washington, DC. : H.L. \& J.B. McQueen, Inc. 176 p.

Polakowsky, H. (1890). Antigüedades de Costa Rica. Anales del Instituto FísicoGeográfico Nacional, 3: 138-140.

Ridgway, R. (1923). In memoriam: José Cástulo Zeledón. The Auk 40: 682-689.

Rojas, V. M. \& Sandí, J. A. (comp.). (2011). Estudios historiográficos de Monseñor Bernardo Augusto Thiel. San José: EUNED. 276 p.

Salazar, O. (2002). El apogeo de la república liberal en Costa Rica 1870-1914. Colección Historia de Costa Rica. San José: Editorial de la Universidad de Costa Rica. 308 p.

Sanabria, V. (1941). Bernardo Augusto Thiel, segundo obispo de Costa Rica (Apuntamientos históricos). San José: Imprenta Lehmann. 650 p.

Wagner, M. \& Scherzer, C. (1974). La República de Costa Rica en Centro América. Serie Nos Ven No. 2. 2 vol. San José: Ministerio de Cultura, Juventud y Deportes. $219 \mathrm{p}$.

Zeledón, E. (comp.). (2003). Crónicas de los viajes a Guatuso y Talamanca del Obispo Bernardo Augusto Thiel. San José: Editorial de la Universidad de Costa Rica. 148 p.

Zeledón, R., Hanson P., \& Zumbado, M. (2014). Guía de artrópodos de importancia médica y veterinaria. San José: EUNED. 135 p. 